Trierer Studien zur Slavistik 7

Борис Норман

\title{
Языковые категории в сознании и творчестве русского поэта
}

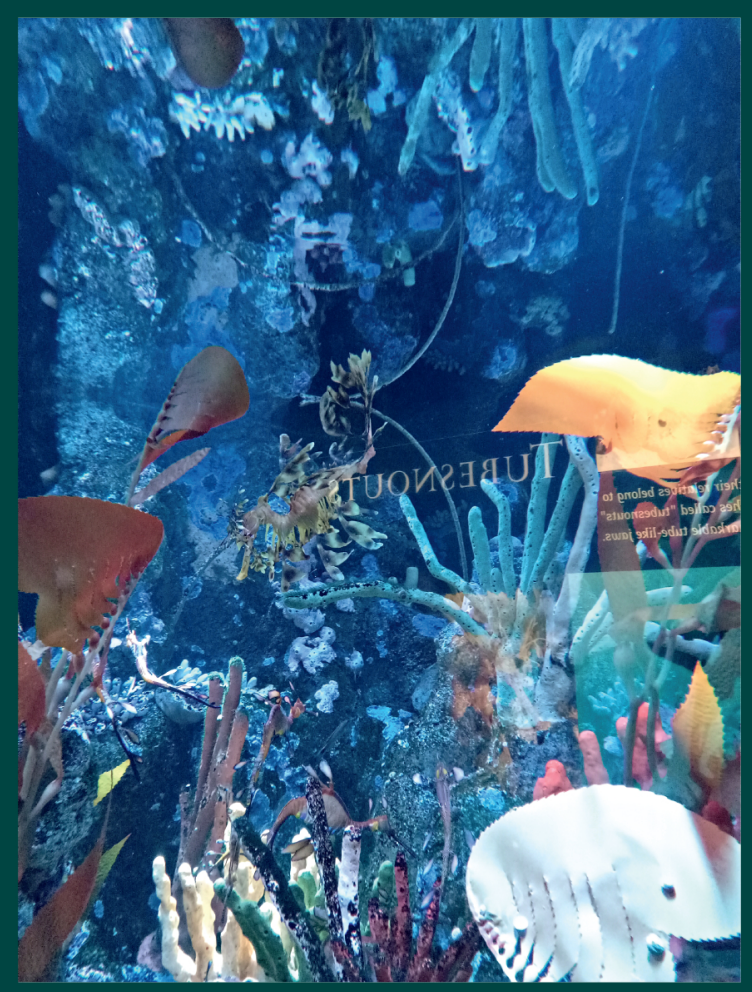




\section{Trierer Studien zur Slavistik 7}

Борис Норман

\section{Языковые категории в сознании и творчестве русского поэта}

Поэзия - сфера свободного словесного творчества. Тем не менее, поэт должен придерживаться каких-то языковых норм. Механизмы внутренней речи, преобразования смысла и эмоций в текст получают в книге лингвистическую интерпретацию. Материалом для наблюдений и выводов служит русская поэзия, в основном XX века (Б. Пастернак, О. Мандельштам, М. Цветаева, Б. Окуджава, Ю. Левитанский, А. Кушнер и др.).

Борис Юстинович Норман - доктор филологии, профессор Белорусского государственного университета (Минск). Книга была выполнена в рамках проекта FOR 2603 Russischsprachige Lyrik in Transition: Poetische Formen des Umgangs mit Grenzen der Gattung, Sprache, Kultur und Gesellschaft zwischen Europa, Asien und Amerika в университете Трира.

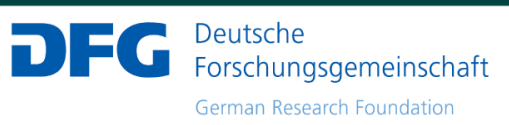


Языковые категории в сознании и творчестве русского поэта 


\title{
Trierer Studien zur Slavistik
}

\author{
Herausgegeben von \\ Alexander Bierich, Gerhard Ressel \\ und Henrieke Stahl
}

Band 7

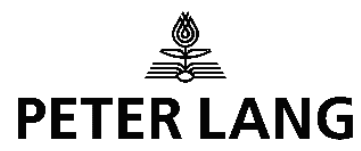


Борис Норман

\section{Языковые категории в сознании и творчестве русского поэта}

\section{(8) \\ PETER LANG}




\section{Bibliografische Information der Deutschen Nationalbibliothek}

Die Deutsche Nationalbibliothek verzeichnet diese Publikation in der Deutschen Nationalbibliografie; detaillierte bibliografische Daten sind im Internet über http://dnb.d-nb.de abrufbar.

Entstehung und Druck des Buches wurden von der DFG-Kollegforschungsgruppe FOR 2603 finanziert.

Das Motiv für das Cover stammt von Henrieke Stahl.

Gedruckt auf alterungsbeständigem, säurefreiem Papier. Druck und Bindung: CPI books GmbH, Leck

$$
\begin{gathered}
\text { ISBN 978-3-631-81797-1 (Print) } \\
\text { E-ISBN 978-3-631-82794-9 (E-PDF) } \\
\text { E-ISBN 978-3-631-82795-6 (EPUB) } \\
\text { E-ISBN 978-3-631-82796-3 (MOBI) } \\
\text { DOI 10.3726/b17212 }
\end{gathered}
$$
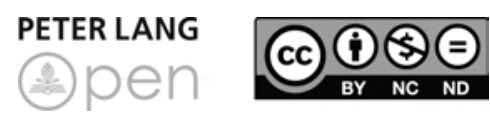

Open Access: Dieses Werk ist lizensiert unter der Creative Commons Lizenz Namensnennung - Nicht kommerziell - Keine

Bearbeitungen 4.o International (CC BY-NC-ND 4.0). Den vollständigen Lizenztext finden Sie unter: https://creativecommons.org/licenses/by-nc-nd/4.o/deed.de

(C) Борис Норман, 2020

Peter Lang - Berlin · Bern · Bruxelles · New York •

Oxford $\cdot$ Warszawa $\cdot$ Wien

Diese Publikation wurde begutachtet. www.peterlang.com 


\section{Содержание}

$\begin{array}{ll}\text { Предисловие } & 7\end{array}$

Глава 1. Поэт как лингвист (лингвистические наблюдения и 9 открытия в русской поэзии)

Глава 2. Лингвист как поэт: переключение кодов или смена 42 парадигмы? (анализ поэтического творчества профессиональных языковедов)

Глава 3. «Отдаленное знакомство слов» (о семантических и 71 фонетических связях между словами в стихотворении)

Глава 4. О борьбе строки с предложением (и о смысле невы- 96 раженном, но реконструируемом)

Глава 5. Особенности глагольного управления в поэтическом 111 тексте (и падежные вариации в стихотворении Ю. Левитанского)

Глава 6. Лексические повторы и случаи прономинафобии в поэзии (существительные против местоимений?)

Заключение

Список цитированной литературы 



\section{Предисловие}

Язык русской поэзии всегда привлекал мой исследовательский интерес. Этим был обусловлен ряд предыдущих публикаций, посвященных творчеству Ф. Тютчева, И. Анненского, О. Мандельштама, А. Ахматовой, А. Вознесенского.

Счастливая возможность, предоставленная Немецким Исследовательским Обществом (DFG) и Университетом Трира, позволили мне в марте-июне 2019 года сосредоточиться на данной проблематике и подготовить в рамках проекта FOR 2603 «Russischsprachige Lyrik in Transition: Poetische Formen des Umgangs mit Grenzen der Gattung, Sprache, Kultur und Gesellschaft zwischen Europa, Asien und Amerika» цикл новых работ. Они объединены в данную книгу.

Структура книги такова.

Первый раздел, самый большой, исследует представления поэтов о языке, отраженные в их творчестве. Временной диапазон здесь широкий - от XVIII века до наших дней, но основное внимание уделяется русской поэзии второй половины XX века (Пастернак, Тарковский, Левитанский, Самойлов, Вознесенский, Окуджава и др.).

Второй раздел в каком-то смысле зеркален первому: в нем анализируются стихотворные произведения профессионалов-лингвистов. Ставится вопрос о соотношении двух видов творчества - научного и поэтического - в их сознании.

Третий раздел посвящен соотношению двух составляющих поэтического творчества: смыслового и формального факторов. Одновременно выявляются случаи сложных, цепочечных ассоциаций между словами.

Темой четвертого раздела является соотношение двух единиц и способов организации стихотворного текста: предложения и строки. Демонстрируются особые случаи их взаимодействия, включая анжамбеман.

Пятый раздел содержит анализ лексико-грамматической сочетаемости слов в поэзии. В центре внимания здесь - два «конца» глагольного управления, соединяющего в себе семантические классы слов с правилами синтаксической связи.

Шестой раздел рассказывает о лексических повторах в стихотворениях, о субститутной и анафорической роли местоимений 3-го лица и случаях преднамеренной «прономинафобии».

Все вместе эти разделы дают представление об участии языковых единиц и категорий в процессе поэтического творчества, начиная от этапа интенции и кончая воплощением в готовый текст. 
Я бы хотел выразить искреннюю благодарность руководителям проекта - профессору Хенрике Шталь и профессору Александру Бириху - за творческую атмосферу и плодотворное сотрудничество, а также всему интернациональному коллективу, способствовавшему достижению поставленных научных целей. 


\section{Глава 1. Поэт как лингвист (лингвистические наблюдения и открытия в русской поэзии) ${ }^{1}$}

Р. Якобсон в своей ставшей уже классической статье показал, что поэтическое творчество обусловливается «принудительным характером грамматических значений» и в то же время сама грамматика обладает внутренней поэзией ${ }^{2}$. Он обратил внимание на такие черты поэтических текстов, как синтаксический параллелизм, противопоставленный ему «органический хаос» и использование звукописи. В развитие данной темы попытаемся проанализировать: что такое язык с позиций поэта, каково отношение творца к своему инструменту, что он находит в нем?

Проблема «поэт как лингвист» уже не раз была предметом научных исследований ${ }^{3}$, но она остается актуальной как в собственно научном плане, так и с позиций массового читателя. Показательно, в частности, что значительная часть приводимых в этом разделе примеров выбрана нами из вышедшего несколькими изданиями сборника 4 . Почему же отношение поэта к слову оказывается для нас таким важным?

Во-первых, поэт - полноправный носитель языка. А человек знает о языке, которым он пользуется, очень много. Другое дело, что он не всегда способен эти свои знания эксплицировать, выразить в словесной форме - но уж для поэта это - его привычное ремесло. В то же время поэту как носителю языка, очевидно, свойственно ошибаться, он может разделять какие-то заблуждения, превратные представления о языке, бытующие среди людей. Поэтому стихи - яркое проявление речетворческой способности народа.

Во-вторых, настоящий поэт богоподобен и богоравен. Он способен на гениальные прозрения, на откровения, он - демиург, видящий сквозь время и пространство. Слова Е. Евтушенко «Поэт в России больше, чем поэт...»5 стали уже крылатыми. Но поэт везде, в любой стране, - больше, чем поэт. Если у народа есть душа, то поэт - ее голосовые связки. Эта мысль - о том,

Основу данного раздела составили две переработанные и значительно дополненные публикации автора: Норман Б.Ю. (2011): Лингвистические наблюдения и открытия в русской поэзии // Русский язык и литература. Минск. № 5. С. 3-11; Норман Б.Ю. (2012): Лингвистика поэзии: прозрения и заблуждения. В кн.: Лингвистика креатива. Коллективная монография / Под ред. Т.А. Гридиной. Екатеринбург: Уральский государственный педагогический университет. С. 177-198.

2 Якобсон $(1983$, с. 472$)$.

3 Григорьев (1979); Григорьев (1983); Ионова (1988); Зубова (200о); (Зубова 2010); Коновалов (2018) и др.

4 Поэты о русском языке (1989).

5 Евтушенко (1980, 1, с. 395). 
что устами поэта глаголет язык, - многократно высказывалась художниками слова. Может быть, ярче всего ее выразил Иосиф Бродский:

Поэт - слуга языка. Он и слуга языка, и хранитель его, и двигатель. И когда сделанное поэтом принимается людьми, то и получается, что они в итоге говорят на языке поэта, а не государства 6 .

И еще одна цитата, из лекции Бродского при вручении ему Нобелевской премии:

Поэт всегда знает, что то, что в просторечии именуется голосом Музы, есть на самом деле диктат языка; что не язык является его инструментом, а он средством языка к продолжению своего существования7.

В принципе, эта идея - господства языка над человеком - не чужда и лингвистам. Основатель философской герменевтики Х.-Г. Гадамер писал: Es ist buchstäblich richtiger zu sagen, dass die Sprache uns spricht, als dass wir sie sprechen ${ }^{8}$ «На самом деле правильнее сказать, что язык говорит нами, чем что мы говорим языком». И, по сути, этому трудно возразить, если понимать, что язык - достояние коллектива, а индивид этим коллективным достоянием только пользуется.

Но та же мысль не раз выражалась и в поэтической форме. Так, Арсений Тарковский в программном стихотворении «Явь и речь» писал:

Не я словарь по слову составлял,

А он меня творил из красной глины...9.

Уральский поэт Юрий Казарин придал этой максиме форму прозаического хиазма: «Не я пытаюсь сказать что-то стихами. Это стихи вынуждают меня говорить» ${ }^{10}$.

Сравним у Дмитрия Сухарева, в стихотворении «Должность»:

Слова

Выстраивают поэта,

Как он расставляет их,

И нет у него портрета,

Иного, чем свой же стих ${ }^{11}$.

А петербуржец Александр Кушнер поднимается еще выше в своем обобщении:

А теперь и представить не в силах

Ровной жизни и мирной любви.

\footnotetext{
6 Волков (2004, с. 188-189).

7 Бродский (1992, 2, с. 460).

8 Gadamer (1975, S. 439).

9 Тарковский (1982, с. 164).

10 Казарин (2006б, с. 222).

11 Сухарев (1989, с. 348).
} 
Что однажды блеснуло в чернилах,

То навеки осталось в крови

(«Слово «нервный» сравнительно поздно...») ${ }^{12}$.

Это значит - литература оборачивается жизнью, язык создает мир, он в каком-то смысле оказывается первичным по отношению к действительности...13

Возвращаясь к мотивировке выбранной нами темы, добавим: у поэта нередко бывает филологическое образование. Это, конечно, не значит, что на филфаке «учат на писателей». Когда того же Бродского на суде спросили: «А кто установил, что вы - поэт? Кто вас зачислил в ряды поэтов?.. Вы учились этому?», тот ответил: «Я не думал, что этого можно достичь образованием... Я думаю, что это... от Бога» ${ }^{14}$. Но филологическое образование может помочь поэту заметить те или иные особенности языка и акцентировать их в своем творчестве. Недаром у многих прекрасных современных поэтов - В. Кривулина, М. Крепса, А. Парщикова, А. Кушнера, О. Чухонцева, М. Еремина, Л. Лосева и других - за плечами филфак или Литинститут.

В общем, тема «Поэт как лингвист» имеет свои разные основания и разные аспекты исследования. Можно согласиться с Л.В. Зубовой:

Лингвистическая теория во многом опирается на исследование границ допустимого в нормативном языке. Поэты тоже исследуют границы допустимого - нарушая их. При этом поэты, предлагая увидеть мир в неожиданном ракурсе, исследуют не только выразительные, но и познавательные возможности языка, предоставляя обширный материал для размышлений над свойствами языка в его когнитивной функции ${ }^{15}$.

Именно с этого мы и начнем: с общих аспектов строения и функционирования языка.

То, что язык - основа мышления, что благодаря языку мы не только общаемся, но и познаем себя и окружающий мир, понимали русские поэты уже в XVIII веке. Причем когнитивная функция языка изначально связывалась главным образом с такой единицей, как слово. Именно слово называет предмет, отражает положение дел в мире и позволяет хранить соответствующую информацию в сознании. Вот как писал Г.Р. Державин в своем «Послании к Великой княгине Екатерине Павловне...» - эти слова часто цитируют нынешние учителя-словесники:

Язык всем знаниям и всей природе ключ;

Во слове всех существ содержится картина... ${ }^{16}$.

12 Кушнер (1991, с. 33).

13 Норман, Куссе (2018, с. 143-171).

14 Стуков $(1965$, с. 5$)$.

15 Зубова (2009, с. 39).

16 Державин (1866, 3, с. 529). 
Но в XX веке поэты придали данной мысли поистине изящное воплощение. Может быть, лучшее тому свидетельство - известное стихотворение Самуила Маршака «Словарь»:

Усердней с каждым днем гляжу в словарь.

В его столбцах мерцают искры чувства.

В подвалы слов не раз сойдет искусство,

Держа в руке свой потайной фонарь.

На всех словах - события печать.

Они дались недаром человеку.

Читаю: «Век. От века. Вековать.

Век доживать. Бог сыну не дал веку.

Век заедать, век заживать чужой...».

В словах звучит укор, и гнев, и совесть...

Нет, не словарь лежит передо мной,

А древняя рассыпанная повесть ${ }^{17}$.

Словарь, лексикон, вокабулярий - собрание слов, содержащихся в памяти языкового коллектива. Он отражает не только совокупность реалий, среди которых живет человек, но и культуру народа в самом широком смысле: систему идеалов и нравственных принципов, гамму чувственных ощущений, шкалу принятых оценок, порождения фантазии и т.п. Поэтому писатель, художник, творец, имеющий дело со словом, фактически обращается к глубинам народного сознания. Конечно, не всегда эти ощущения, эти впечатления можно объяснить разумом. Вот как сказал об этом М.Ю. Лермонтов («Есть речи - значенье...»):

Есть речи - значенье

Темно иль ничтожно,

Но им без волненья

Внимать невозможно... ${ }^{18}$.

И почти о том же, и похожими словами - у Афанасия Фета в стихотворении «Почему?»:

Почему светлой речи значенья

Я с таким затрудненьем ищу?

Почему и простые речения,

Словно томную тайну, шепчу?'9

Но и в самых обычных, затертых словах - таких, как дом, дерево, стол, красный, работать, - поэта подстерегают неожиданные открытия. В частности, Давид Самойлов признался («Слова»):

17 Маршак $(1958,2$, с. 20$)$.

18 Лермонтов (1961, 1, с. 474).

19 Фет (1986, с. 312). 
Люблю обычные слова,

Как неизведанные страны,

Они понятны лишь сперва,

Потом значенья их туманны.

Их протирают, как стекло,

И в этом наше ремесло ${ }^{20}$.

Слово, название, имя - инструмент познания мира. Проблема «слово и вещь (предмет)» для языкознания - одна из изначальных и до сих пор актуальных ${ }^{21}$. Практический разум подсказывает нам, что название в значительной степени условно и произвольно. Народ говорит: Хоть горшком назови, только в печку не ставь. Более изящно выражена эта мысль в строках Шекспира («Ромео и Джульетта»), знакомых нам по переводу Бориса Пастернака:

Что есть Монтекки? Разве так зовут

Лицо и плечи, ноги, грудь и руки?

Неужто больше нет других имен?

Что значит имя? Роза пахнет розой,

Хоть розой назови ее, хоть нет ${ }^{22}$.

Давая предмету название, человек «метит» его, выделяет из общей массы вещей, делает его «своим», частью своего мира. Эта номинативная функция языка, составляющая условие и пару к функции когнитивной, также отражается в русской поэзии. Предмет нуждается в словесном обозначении для того, чтобы стать собой, самоидентифицироваться. Характерна мольба Осипа Мандельштама:

Не забывай меня, казни меня,

Но дай мне имя, дай мне имя:

Мне будет легче с ним - пойми меня

В беременной глубокой сини

(«Как тельце маленькое крылышком...») $)^{23}$.

Эта «означивающая» миссия создает у поэта иллюзию, что он обладает статусом творца, Демиурга - с помощью слов он способен создавать и изменять миры. В качестве иллюстрации - строки Иосифа Бродского:

Да и копоть твоя воспаряет выше

помыслов автора этих строчек.

Впрочем, в ихнем ряду ты обретаешь имя;

вечным пером, в память твоих субтильных

запятых, на исходе тысячелетья в Риме

20 Самойлов (1989, с. 65).

21 Фуко (1994, с. 34).

22 Шекспир (1982, с. 256).

23 Мандельштам (1990, 1, 152). 
я вывожу слова «факел», «фитиль», «светильник», а не точку - и комната выглядит как в начале («Римские элегии») 24 .

(Заметим, что рядом с высокими и вечными помыслами забавно выглядит просторечное местоимение ихний; но Бродский, вслед за Маяковским, любил это слово.)

Те же «демиургические» мотивы находим у Юрия Казарина:

Сквозь двойное стекло лампы настольной, окна,

Тенью к стене пришивая предметы,

Свет раздает пустоте имена -

Контурам, дырам, дымку от моей сигареты

(«Сквозь двойное стекло...») $)^{25}$.

Понятно, что свет в данной ситуации - только внешнее условие, а «раздача» имен - прерогатива человека, организующего и в этом смысле создающего действительность.

Как известно, в античной науке разногласия о природе имени отразились в противопоставлении теорий «фюсей» и «тесей». Кратил в одноименном диалоге Платона отстаивал идею природного соответствия названия своей вещи; другой философ, Гермоген, ему возражал, указывая, что имя устанавливается по обычаю или «по договору». Сегодня мы понимаем правоту Гермогена, однако и доводы Кратила кажутся не совсем беспочвенными. Исконная связь названия с предметом отражается не только в звукоподражании и звукосимволизме (ср. какие-нибудь слова типа рус. грохот, писк, рёв, скрипеть, визжать, бултыхаться и т.п.), но и в безотчетных ощущениях носителя языка, когда ему какое-то слово «не нравится по звучанию». В наши дни гиперболизация силы слова, своего рода семантический идеализм, принимает подчас анекдотические формы. Согласно представлениям обывателя, стоит «исправить» название, заменить, скажем, Верховный Совет на Государственную Думу, Сберкассу на Сбербанк, а милицию на полицию, - и жизнь изменится в лучшую сторону. Один из обэриутов (членов литературного Объединения Реального Искусства), Николай Олейников, в свое время иронически высказался по этому поводу так:

Быть может, с фамилией новой

Судьба моя станет иной,

И жизнь потечет по-иному,

Когда я вернуся домой

(«Перемена фамилии») ${ }^{26}$.

24 Бродский (1992, 2, с. 99).

25 Казарин (2006б, с. 500).

26 Олейников (1990, с. 151). 
А сегодня другой поэт, А. Аронов, говорит о таких изменениях с искренней надеждой:

Когда мы уточним язык

И камень назовем как надо,

Он сам расскажет, как возник,

В чем цель его и где награда.

Когда звезде подыщем мы

Ее единственное имя -

Она, с планетами своими,

Шагнет из немоты и тьмы...

(«Когда мы уточним язык...») $)^{27}$.

Если же предмет лишен названия, не обозначен на карте общественного понятийного мира, то это может вызывать у человека только сочувствие или сожаление. Иногда такое отношение к «неназванному» - часть общего пантеистического взгляда на мир. Всё, что нас окружает, - столь же совершенно, как и человек, и лишь обстоятельства позволили последнему возвыситься над своими меньшими братьями. Животные, в частности, не заслужили имен; дифференциация, подобная той, что существует среди людей, им ни к чему. По словам Николая Заболоцкого,

У животных нет названья.

Кто им зваться повелел?

Равномерное страданье -

Их невидимый удел

$$
\text { («Прогулка») }{ }^{28} \text {. }
$$

А современнику и соратнику Заболоцкого по ОБЭРИУ, а также по журналам «Чиж» и «Еж», Николаю Олейникову названия и вовсе не нужны; предметы сами становятся знаками. Обостренное мировосприятие художника создает вокруг него мир всеобщего семиозиса:

Все пуговки, все блохи, все предметы что-то значат.

И неспроста одни ползут, другие скачут. [...]

Тебе селедку подали. Ты рад. Но не спеши ее отправить в рот.

Гляди, гляди! Она тебе сигналы подает!

(«Озарение») $)^{29}$.

Еще одна цитата, из другого стихотворения того же автора:

И слово чудное «бутылка»

Опять встает передо мной.

Салфетка, перечница, вилка -

27 Аронов $(1987$, с. 58$)$.

28 Заболоцкий $(1983,1$, с. 81$)$.

29 Олейников (1990, с. 102). 
Слова, прекрасные собой...

(«На выздоровление Генриха») $)^{30}$.

Подобным образом и Арсений Тарковский в стихотворении «Я учился траве, раскрывая тетрадь...» обращает свой исследовательский интерес непосредственно к природе, к вещам, отождествляя словесные знаки с их денотатами. Слова утрачивают собственный смысл и необходимость, срастаясь с предметами в этаком первобытном синкретизме:

В слове правда мне виделась правда сама.

Был язык мой правдив, как спектральный анализ.

А слова у меня под ногами валялись...

(« Я учился траве, раскрывая тетрадь...») $)^{31}$.

По-видимому, для таких разных поэтов, как Олейников и Тарковский, мир предметов образует некий код, способный сообщать посвященному разнообразную информацию. Предметы «немы» только до тех пор, пока они нам незнакомы. Иными словами, мир вокруг нас значим, надо лишь уметь его читать, как книгу... Но проходят десятки лет - и другие поэты вновь и вновь задаются тем же вопросом:

Туча по небу промчит

Мышь когтями застучит

То ребенок вдруг заплачет

За дощатою стеной

То ли это что-то значит

То ли так - само собой

(Д. Пригов. «То все тихо, то внезапно...») $)^{32}$.

Еще один способ решить проблему «слово и вещь» можно было заметить на примере цитированных строк Тарковского и Олейникова. Этот способ - объединить данные два понятия, слить их в сознании поэта. В стихотворении Новеллы Матвеевой «Сводники» такой путь абсолютизируется в шутливой форме: словам приписываются отношения предметов:

Кухарка вышла замуж за компот,

Взял гусеницу в жены огородник,

Грядущий день влюбился в прошлый год,

А виноваты - сводница и сводник ${ }^{33}$.

Неудивительно, что именно этот прием обыграл Юрий Левитанский в своей пародии на Новеллу Матвееву:

30 Олейников (1990, с. 122).

31 Тарковский (1982, с. 50).

32 Пригов (1997б, с. 115).

33 Матвеева (1966, с. 112). 
Окрошка вышла замуж за кисель, Кастрюлю в жены взял чревоугодник...

$$
\text { («Не в соли - соль» })^{34} \text {. }
$$

Понятно, что окрошка и кисель (так же как кастрюля и чревоугодник и т.п.) - слова из одной лексико-семантической группы. Но в реальности, у самих предметов, общего практически нет. Только поэт может, отталкиваясь от языка, им эту общность придать - скрепить «брачными узами».

Есть, кстати, теоретически еще более простой вариант: назвать все предметы одним и тем же именем. Если название условно, то почему бы не использовать одно и то же имя для бесконечного множества предметов? Фантазия поэта не имеет лингвистических пределов. Дмитрий Пригов неожиданно предлагает такое преломление проблемы имени собственного:

Всё в округе звали «Катя»

Это проще, так сказать

Если хочешь что сказать

Говоришь спокойно: Катя

И всё откликается и прибегает

Это гораздо проще -

Не надо каждого отдельно заставлять и упрашивать...

(«Детские стихи»)35.

Но понятно, что этот парадоксальный путь абсурден: если «у всех одно имя» - это всё равно, что имен вообще нет. Название оказывается условным знаком, но только с оговоркой, что оно в каждом случае свое (омонимы составляют на этом фоне исключение). То, что имена должны быть разными, мы наблюдаем на практике. Даже если в классе три Даши и пять Кать, это уже составляет некоторую проблему для их идентификации и дифференциации.

Впрочем, не для всех современных стихотворцев окружающий мир нуждается в «прочтении», «расшифровке» и осмыслении. Так, следующее произведение рассчитано на подрастающее поколение, поэтому тезис о связи между денотатом и названием принимает в нем прямолинейнонравоучительную форму:

Всему название дано -

И зверю, и предмету.

Вещей вокруг полным-полно,

А безымянных - нету!

И всё, что может видеть глаз -

Над нами и под нами, -

34 Левитанский (1982, с. 456).

35 Пригов (2017). 
И всё, что в памяти у нас, -

Означено словами

(А. Шибаев. «Слова, слова, слова») ${ }^{36}$.

Это вообще довольно распространенное заблуждение - представление о том, что язык слепо отражает номенклатуру действительности, следует за нею. Раз есть предмет - значит, у него должно быть название, и наоборот: раз есть название - соответственно, за ним должен стоять предмет.

Заметим, что в научно-популярной литературе подобная точка зрения встречается нередко. Вот какой декларацией начинается одно пособие для учащихся старших классов: «Всё в окружающем нас мире имеет название» 37 . По сути же это даже не упрощение, а извращение положения дел. Дело в том, что название для человека - не самоцель, а условие и составная часть познавательного процесса. Если всё уже названо, это значит, что всё уже познано и нет смысла идти по этому пути дальше. Фактически «всему название дано» - это признание когнитивного коллапса, краха. И видеть в языке зеркальное отражение действительности - значит не понимать природы языка.

Бездонная глубина содержания слова может вызывать у человека разные чувства: может - восхищения и гордости, а может - неуверенности или даже страха пред процессом его познания и употребления. Слово, по выражению М.В. Всеволодовой, только «ночует» в словаре, а живет оно в тексте, переливаясь всеми смысловыми оттенками. Вот как об этом переливчатом многообразии говорит поэт:

Как мы, едва слова употребив,

Им придаем значение иное

(Ю. Мориц. «К весне») $)^{38}$.

А Осип Мандельштам в «Разговоре о Данте», создавая поэтический образ слова и процесса его употребления, пользуется почти лингвистическими терминами:

Любое слово является пучком, и смысл торчит из него в разные стороны, а не устремляется в одну официальную точку. Произнося «солнце», мы совершаем как бы огромное путешествие, к которому настолько привыкли, что едем во сне. Поэзия тем и отличается от автоматической речи, что будит нас и встряхивает на середине слова 39 .

Сегодня семасиология уже более или менее уверенно оперирует смысловыми «кирпичиками», разлагая значения на отдельные семы (семантические множители). Мы говорим, например: рука - «верхняя конечность

36 Поэты о русском языке (1989, с. 181).

37 Голанова (1989, с. 6).

38 Мориц (1974, с. 57$)$.

39 Мандельштам (1990, 2, с.223). 
человека», и эти три признака предмета с необходимостью и достаточностью образуют понятие и являются основой для описания значения слова. (А, допустим, признаки «правый», «левый», «мужской», «в перчатке» и т.п. таковыми не являются, они для значения слова рука факультативны.) Разработана типология сем: различаются категориальные семы, гиперсемы, коннотативные, потенциальные семы и т.д. Остается только соотнести результаты логического анализа с той реальной комбинацией семантических множителей, с которой мы имеем дело в речи. Совершенствование метода компонентного анализа приводит к составлению и сопоставлению инвентарей сем ${ }^{40}$. Во всяком случае, проанализировать понятие, разложить его на составляющие, на основные признаки, и на их основе вывести толкование - сегодня посильная задача для студента-филолога. Не то - для поэта: сама мысль о возможности препарирования мысли приводит его в ступор:

Когда бы вдруг ученые смогли

Понятье расщепить, как ныне атом,

Тогда мы не узнали бы земли, -

Земля тогда бы тотчас стала адом!

Что жизнь? Что смерть? Что холод? Что тепло?

Как зыбко всё. Ни доброго, ни злого!

Всё рухнуло тогда бы... Погребло

Мир под собой взорвавшееся слово!

(Е. Винокуров. «Слово») ${ }^{41}$.

И, если не видеть в этих строках просто поэтической позы, то как объяснить такое неприятие логического анализа? В чем корни мистического ужаса перед познанием, перед разъятием мысли? Думается, что они - в изначальном преклонении перед магией слова, в априорном противопоставлении, разведении по разные стороны барьера науки и искусства. Это то, в чем обескураженно признавался пушкинский Сальери:

...Звуки умертвив,

Музыку я разъял, как труп. Поверил

я алгеброй гармонию...

(«Маленькие трагедии») $4^{42}$,

- но при этом исчезала сама музыка. А через полтораста лет советский поэт сравнил научное познание с препарированием Царевны-лягушки:

В долгих муках она умирала -

В каждой жилке стучали века!

И улыбка познанья играла

40 Reuther (2003).

41 Поэты о русском языке (1989, с. 73).

42 Пушкин (1957, 5, с. 357). 
На счастливом лице дурака

(Ю. Кузнецов. «Атомная сказка») 43 .

Смысл этих строк понятен: не трогайте сказку, не пытайтесь проанализировать чудо - оно просто исчезнет!

С одной стороны, безотчетная вера в магию, в силу слова (фидеизм) всегда была свойственна человеку. Учитель Кун (Конфуций), когда его спросили, с чего бы он начал управление государством, ответил: «С исправления имен». Если имена неправильны, то слова не имеют под собой оснований. Если слова не имеют под собой оснований, то дела не могут осуществляться...

С другой стороны, познание безгранично, и слова, названия - только инструмент в этом процессе. Со временем накопленный человечеством опыт позволяет вынести какие-то знания в «пресуппозицию» - трактовать их как само собой разумеющиеся. В том числе трудно отрицать и прогресс в языкознании: как сама природа языка, так и его устройство становятся все понятнее исследователям. Добавим, что в науке существует и механистический взгляд на структуру художественного смысла (вспомним классическую декларацию Виктора Шкловского: «Я знаю, как сделан автомобиль, я знаю, как сделан Дон Кихот»)44.

Вся структурная поэтика самим фактом своего существования опровергает агностицизм по отношению к плану содержания художественного текста. И все же магическая составляющая - очень сильный довод в споре о познаваемости смысла, о возможности его анализа! Магия языка нуждается и в жреце, и в толкователе. Если поэт - жрец, то филолог толкователь, посредник между языком (соответственно текстом) и обычным человеком. Отсюда - особое доверие к тому, чья профессия - разъяснять, проникать вглубь текста, а если нужно, то и «поправлять» язык. «Не то слово употреблено? А нужно вот какое! Нет подходящего названия? А мы придумаем!» - такое представление о миссии филолога нередко бытует и в стихах.

- Ничего, - говорят лексикографы,

составители. - Не беда!

Напряжем свои умные головы

и подыщем словцо без труда

(Б. Слуцкий. «Слово и понятие “свобода”»)45.

На самом деле не филологи (в абсолютном большинстве случаев) придумывают новые слова - это делает народ, и потому новообразования анонимны. А вот поэт недаром - творец. И в стремлении создать свой особый мир он не собирается рассчитывать на помощь лексикографа. Это пусть

43 Кузнецов (1968).

44 Ларин (1974, с. 49).

45 Поэты о русском языке (1989, с. 74). 
лингвист идет по стопам поэта. Об этом хорошо сказала Белла Ахмадулина:

Каков окликнуть безымянность способ?

Не выговорю и не говорю...

Как слово звать - у словаря не спросишь,

Покуда сам не скажешь словарю

(«Я лишь объем, где обитает что-то...») $)^{46}$.

Со временем язык меняется, эволюционирует - об этом можно судить даже основываясь на речи одного поколения. Изменения в значении слов, в формообразовании, в синтаксисе не уходят от взгляда литератора, а иногда и составляют предмет специального внимания. Насколько глубоко поэт осознает эту проблему? Вот философское ее представление:

Как мир меняется! И как я сам меняюсь!

Лишь именем одним я называюсь, -

На самом деле то, что именуют мной, -

Не я один. Нас много. Я - живой...

(Н. Заболоцкий. «Метаморфозы») 47.

Язык - живой, это надо хорошо понимать. Испытывая пиетет к словарю как к истине в последней инстанции, какой-нибудь журналист или политолог нередко приводит в качестве последнего аргумента ссылку на Толковый словарь Даля. Ему, может быть, невдомек, что Владимир Даль собирал по крупицам свой словарь примерно полтораста лет назад. И ныне этот подвижнический труд представляет собой скорее справочник по истории и этнографии русского народа, чем указатель по современному словоупотреблению... Носителю же языка кажется, что словарь - не просто минимально систематизированное хранилище слов, а своего рода Оракул или распорядитель, поощряющий одни названия и «задвигающий» другие на периферию нашего сознания. Недалеко от этого взгляда уходит и поэт:

Кто нынче скажет «окоём»,

Иль «росстани», иль «первопуток» -

Всё, что Толковым словарем

В безвестный загнано закуток?

Слова угасшей старины

Вдали мерцают еле-еле,

А прежде, жизнью рождены,

Они ласкали, жгли и пели...

(Вс. Рождественский. «Ветшают прадедов слова...») $)^{48}$.

46 Поэты о русском языке (1989, с. 139).

47 Заболоцкий $(1983,1$, с. 191).

48 Поэты о русском языке (1989, с. 97). 
Но, конечно, не словарь виновен в том, что язык развивается, что отдельные слова устаревают и забываются. Он только фиксирует этот процесс, в крайнем случае - сдерживает его. К примеру, слово смычка имеет в качестве одного из значений такое: 'союз, совместность действий, объединение и согласованность интересов' (классический контекст - смычка города с деревней). В Толковом словаре под редакцией Д.Н. Ушакова 49 это значение дается с пометами «нов.» и «полит.». В новейших словарях оно приводится без каких-либо помет, хотя уже вполне могло бы иметь помету «устар.»: фактически перед нами архаизм. Словари вообще консервативны, они с опозданием фиксируют изменения в жизни языка. В том числе, как мы видим, они пытаются как бы замедлить процесс старения слова, продлить его жизнь...

Еще пример: наречие намедни. В том же Словаре Ушакова оно сопровождается пометой «простореч.», через полстолетия в Словаре под редакцией С.А. Кузнецова ${ }^{50}$ - пометой «разг.». А фактически за это время слово все более устаревало, чему подтверждением служит наблюдение поэта:

Намедни!

Похоже на мед и на медь.

Поет это слово, успев онеметь.

И кануть в такую глубокую даль,

Что помнят о нем только Фасмер и Даль,

И Преображенский -

Настолько стара

Суть слова, чей смысл означает:

Вчера!

$$
\text { (Л. Мартынов. «Намедни») })^{51} \text {. }
$$

Но затем произошла общественная реабилитация (или своего рода реанимация) этого слова. В самом начале XXI века на российском телевидении (на канале НТВ) появился цикл документальных передач Леонида Парфенова с таким названием, и намедни, по крайней мере на какое-то время, обрело вторую жизнь.

В монографии Л.В. Зубовой «Современная русская поэзия в контексте истории языка» прекрасно показано, что современные поэты не только часто используют в своих произведениях архаичную лексику (перси, ланиты, десница, длань и т.п.), но и реконструируют древнюю фонетику и грамматику - причем делают это в значительной степени интуитивно!52 Скажем, восстанавливаются формы глагольной связки есмь (1-е лицо) и еси (2-е лицо) или различаются формы местоимений они и оне, так же как

49 Ушаков (ред.) (1935-1940).

50 Кузнецов (ред.) (1998).

51 Поэты о русском языке (1989, с. 84).

52 Зубова (200о, с. 191-207 и др.). 
числительных одни и одне... Всё это - сильные стилистические средства, и читатель не может их не оценить. В другой своей книге Л.В. Зубова пишет по поводу форм типа нежн или беспечн у Пригова: «В истории языка возникали варианты слова или формы, и впоследствии один из них, не принятый нормативным языком, оказывался востребованным поэзией...»53. Соответственно, словотворчество поэта не произвольно, оно базируется на его чувстве языка: во многих случаях стихотворец «ощущает» исторически существовавшую форму или же создает такую единицу, которая должна восполнить пробел в словообразовании или словоизменении.

Иногда, размышляя о развитии языка, о расширении словарного состава, поэт обращает внимание на важность нового денотата для мира говорящего. Это своего рода прагматическое условие процесса номинации. Согласно такой точке зрения, новое название может быть присвоено только новому предмету:

\section{Язык расширяется снова и снова, никто не поставит ему предела, но право на новое, небывалое слово имеет лишь новое, небывалое дело}

(Б. Слуцкий. «Мудрость языка») 54 .

Впрочем, последнюю максиму иначе как наивной не назовешь: ее категоричность опровергается нашей ежедневной практикой. Даже слова, обозначающие глобальные общественные потрясения последнего века - такие как революция, катастрофа, кризис, перестройка и т.п. - имеют за собой давнюю историю. С другой стороны, сегодня, на наших глазах, масса новых слов возникает без достаточного логического основания, просто как «переназвания», обусловленные эстетическими и социолингвистическими мотивами. Мэрия, риэлтер, скутер, тусовка, стебаться, эксклюзивный и т.п. обозначают хорошо известные вещи. В этом вся природа языка, его право на обновление, на «каприз» и прихоть. Так что возразить Борису Слуцкому можно его собственными строками из другого стихотворения:

В общем, логике не уступает, поддаваться не хочет язык, как захочет, так поступает, совершает так, как привык...

$$
\text { («Слово “западник” и слово “славянофил”») })^{55} \text {. }
$$

В лингвистике данная проблематика соотносится с теорией номинации, которая говорит об избирательности и - в каком-то смысле - о случайности названий. Для того, чтобы получить название, предмету надо пере-

53 Зубова (2010, с. 184).

54 Поэты о русском языке (1989, с. 73$)$.

55 Слуцкий $(1984$, с. 105). 
шагнуть определенный порог общественной значимости, войти в «светлое поле» сознания. Что же касается поэтических текстов, то здесь необходимость о-значивания предмета обусловливается как содержательными, так и формальными предпосылками.

Именно по поводу соотношения плана содержания и плана выражения слова чаще всего рефлексируют поэты. В частности, их интересует: случайно ли то или иное наименование дано определенному предмету? Есть ли внутренняя, смысловая связь между сходно звучащими словами? В процессе творчества мысль предопределяет выбор слова или слово ведет за собой мысль? Вот где непресыхающий источник поэтических открытий и откровений!

Иосиф Бродский в своих беседах с Соломоном Волковым высказался прямо: «Для поэта между фонетикой и семантикой разницы почти нет» ${ }^{5}$. Он же показывал на конкретном примере, как звук ведет за собой мысль.

Об этом хорошо говорил Оден: можно написать «Завтра пойдет дождь». Есть даже вероятность, что так оно и будет. Но на самом деле поэту просто надо было срифмовать слова «завтра» и «скорбь» (по-английски, как вы знаете, они рифмуются) 57.

Речь идет об англоязычном поэте, которому нужна рифма к слову sorrow 'скорбь'. И самый простой вариант - выбрать первое приходящее в голову созвучие sorrow - tomorrow. Случайное созвучие перевело действие в план будущего: в плане содержания появился элемент «завтра»!

Фонетические связи - рифма, внутренняя рифма, ассонанс, аллитерация и т.п. - важнейший структурный компонент поэзии. Если в обыденной речи звуковые ассоциации в какой-то степени деструктивны, потому что сбивают говорящего с выбора нужного слова (это паронимы), то в стихотворной они обладают фундаментальной «текстопорождающей функцией» ${ }^{8}$. Естественно, и русские поэты уделяют звуковой стороне стиха свое внимание. Примеров на эту тему не счесть, приведем только три. Первый - из Валерия Брюсова:

Созвучья слова не случайны!

Пусть связь речений далека,

В ней неразгаданные тайны

Всегда живого языка

(«Созвучья слова не случайны!») 59 .

56 Волков (2004, с. 312).

57 Волков (2004, с. 271).

58 Чернейко (2012, с. 12).

59 Поэты о русском языке (1989, с. 127). 
Второй пример - из Льва Озерова:

Природа русской рифмы такова:

Аукаются вовсе не слова,

А их значенья, явленные в звуках.

Как деды возрождаются во внуках, -

Через строку по степени родства, -

Так неожиданно, свободно, кстати

Аукаются звуковые рати...

(«Природа русской рифмы такова...») $)^{60}$.

И третий пример - из Новеллы Матвеевой, которая известна не только своими стихами, но и песнями:

...Но думается мне, что у Шампани

Нет общего с шампунью ничего.

И ведь не все же - в самом деле! - парни -

Родня Парни; не всякое чело

В чулок пролезет; да и Пермь - не в Парме,

Хоть вынести всё это тяжело

$$
\text { («Созвучия» })^{61} \text {. }
$$

Звуковая (или, точнее сказать, буквенно-звуковая) сторона стиха принимает на себя основную долю его экспрессивной нагрузки. Поэтому экспрессивную функцию языка нередко отождествляют с поэтической. Данный аспект литературного творчества связан с функциональной специализацией полушарий головного мозга (которая тоже становится объектом поэтического внимания, о чем речь пойдет ниже). Если, по данным современной нейролингвистики, при логическом («силлогистическом») мышлении у человека доминирует левое полушарие, то создание целостного образа - прерогатива правого полушария. «Диалог полушарий» ${ }^{62}$ естествен для ментальной деятельности индивида. Но, возможно, во внутренней речи поэта значительно сильнее, чем у обычного человека, сплавляются фонетические и семантические элементы, вплоть до образования диффузных фоно-семантических комплексов. В лингвистике неслучайно появляется понятие квазиморфем - лексико-фонетических объединений, напоминающих обычные морфемы, но значительно более расплывчатых как в своей форме, так и в значении.

Удивительно ли, что его [поэта - Б.Н.] звуковое сознание некоторым образом отлично от сознания и усредненного носителя языка, и даже филолога-про-

60 Поэты о русском языке (1989, с. 134).

61 Матвеева (1966, с. 115).

62 Черниговская, Деглин (1984, с. 64-65). 
фессионала? Но, в конце концов, не кто иной, как именно поэт владеет поэтической речью продуктивно, а не только рецептивно, как всякий читательнепоэт ${ }^{63}$.

Связи, существующие между планом содержания и планом выражения слова, носят, по-видимому, более или менее универсальный характер. Так, в работе, выполненной на материале английских, немецких и русских прилагательных, авторы отваживаются на такой широкий вывод:

...Не вызывает никаких сомнений, что слова, объединенные в том или ином языке семантическим сходством, связаны и более сильным по сравнению с другими словами фонетическим подобием. [...] Можно предположить, что в языке действует некоторая закономерность, в силу которой к той или иной семантической парадигме «притягиваются» новые элементы, попавшие в сферу ее фонетического и семантического притяжения ${ }^{64}$.

В принципе, все перечисленные проблемы хорошо известны языковедам, вокруг многих из них не утихают дискуссии. Но можно только поражаться тому, какую неожиданную художественную форму принимают эти коллизии в поэтическом преломлении. Поэты тонко чувствуют и отражают в своем творчестве не только общую природу, но и частные вопросы языка - такие, как природа имени собственного, связь плана содержания и плана выражения слова, своеобразие грамматических категорий, роль порядка слов и т.п. Иногда мысль ученого почти дословно воспроизводится поэтом. Философу Фридриху Ницше принадлежит афоризм: Je crains bien que nous ne nous débarrassions jamais de Dieu, puisque nous croyons encore à la grammaire... ${ }^{6}$ «Я боюсь, что мы никогда не избавимся от Бога, так как мы все еще верим в грамматику...». А современный поэт Лев Лосев начинает одно из своих стихотворений словами:

Грамматика есть бог ума.

Решает всё за нас сама...

$(« \text { рамматика есть бог ума...») })^{66}$.

Действительно, грамматика, воплощая в себе высшую степень категоризации действительности, не считает необходимым разъяснять носителю языка те или иные свои особенности (это мы возвращаемся к высказанной выше мысли Р. Якобсона о «принудительном характере грамматики»). Выбор грамматического рода, падежа, вида, времени и т.д. в значительной степени определяется самим языком - индивиду остается только этим правилам подчиниться.

63 Гончаренко (1995, с. 162).

64 Быстрова, Левицкий (1973, с. 596).

65 Nietzsche (1908, p. 130).

66 Лосев (2000, с. 91). 
Но грамматика у поэзии - своя. Привычные синтаксические связи в стихотворном произведении ослабляются. Оснований для этого несколько. Во-первых, предложение как стандартная единица синтаксиса теснится строкой как способом организации текста. Во-вторых, слово приобретает бо́льшую коммуникативную автономию - это приводит и к активизации номинативных, неполных и разного рода фрагментарных предложений ${ }^{67}$. В-третьих, смысл стихотворения складывается в значительной степени на основе суммы (точнее, «произведения») лексических значений. Приведем в качестве иллюстрации стихотворение Юрия Казарина (без названия):

Не за что зацепиться звуком, рукой, слюной глаза, когда ресницу всаживаешь в иной воздух, как шар, сквозящий мимо, в веретено выдоха: настоящий прошлый давным-давно и языком забытый брошенный поперек тени своей, убитый рифмой пастух - пророк, синтаксисом ответа вывернувший гортань, ссыльный - как вывих света как офицер - в Тамань ${ }^{68}$.

Синтаксическая рассыпчатость такого текста компенсируется музыкой ритма, последовательной рифмой по образцу abab и перекличкой метонимически связанных словесных значений: звук - гортань, глаз - ресница, воздух - выдох, рука - вывих, прошлый - забытый, вывернувший вывих и т.п. На всё стихотворение - заметим, только две глагольных формы, зато бросается в глаза обилие причастий. А вот знаки препинания здесь оказываются, по большому счету, без надобности...

Шотландский исследователь Г. Томс, анализируя подобные факты аграмматичности и фрагментарности на материале англоязычной литературы, отмечает: The broad justification for poetic grammar is that the deviations found in literature are interpreted consistently by readers, like normal sentences ${ }^{69}$ - «В широком смысле оправдание для поэтической грамматики заключается в том, что отклонения в текстах последовательно ин-

67 Ковтунова (1986, с. 156).

68 Казарин (2006а, с. 85).

69 Thoms (2008, p. 1). 
терпретируются читателями как нормальные предложения». Исследователь приходит к выводу, что только прагматика, вместе с «теорией релевантности», может объяснить, почему к художественному тексту плохо применим обычный грамматический анализ и почему читатель обычно не замечает в поэзии отклонений от языковой нормы.

Рефлексии поэтов по поводу грамматических категорий можно продемонстрировать на примере хотя бы категории числа. При всей регулярности оппозиции «единственность - множественность», представленной в сфере имени существительного, здесь находится немало случаев нелогичности. То у существительного есть только множественное число, а единственное отсутствует (это так называемые pluralia tantum, вроде сани или ножницы), то, наоборот, слово употребляется, как правило, только в единственном числе (латинское название этого подкласса - singularia tantum: разврат, обилие...). Поэты мгновенно это замечают и обыгрывают в своих стихах, воссоздавая недостающую форму. Большим мастером этого приема был Владимир Маяковский ${ }^{70}$. Но приведем два более свежих примера:

Так в столице, говорят, всякие развраты,

Да и женщин, говорят, больше, чем мужчин

(В. Высоцкий. «Два письма») $)^{71}$.

Такой развес, такой расклад обилий,

Что груз, в котором сад и наши судьбы,

Был поднят без особенных усилий,

Без колебаний уровня в сосуде

(Ю. Мориц. «Сад») $)^{72}$.

Словоформы «развраты» и «обилий» почти не царапают глаз читателя. Но лингвистически это интересные и важные факты: категория числа демонстрирует таким образом свою всеохватность.

У Варлама Шаламова читаем:

Нам все равно - листы ли, листья, -

Как называется предмет,

Каким - не только для лингвистов -

Дышать осмелился поэт...

(«Он из окон своей квартиры...») $)^{73}$.

Расчлененная или собирательная множественность долгое время составляла синкретическое единство (не случайно в русском языке современ-

70 Норман (2012а, с. 36-39).

71 Высоцкий (1993, с. 92).

72 Мориц (1974, с. 99).

73 Шаламов (1988, с. 47). 
ное братья - по происхождению собирательное существительное, вытеснившее исконную форму множественного числа браты или братри). Сегодня собирательность - лексико-грамматическая субкатегория, которая одной своей стороной составляет периферийный «островок» в функционально-семантическом поле числа, а другой стороной, в силу своего выборочного, «штучного» характера, обслуживает лексические значения. Вот на каком фоне реализуются нынешние противопоставления типа листы книги - листья деревьев. Но поэт позволяет себе подняться над этими частностями (или, наоборот, погрузиться в глубины языковой истории)...

А Булат Окуджава воспевает магию числа «два» - что тоже неудивительно с учетом его (числа) уникальной истории. Сущность эволюции понятия «два» в сознании наших предков заключается в соотношении идей множественности и парности. Первая из них, как более общая, постепенно поглощает вторую, и от особого двойственного числа в русском языке сегодня остались только некоторые рефлексы, в том числе окончание множественного числа -a, первоначально обслуживавшее названия парных предметов (бока, рога, глаза, берега...). Но вот как это воспринимает поэт:

Магическое «два». Его высоты,

Его глубины... Как мне превозмочь?

Два сокола, два соболя, две сойки,

Закаты и рассветы, день и ночь...

(«Магическое «два». Его высоты...») 74 .

Варианты форм множественного числа, составляющие стилистическую проблему для современных носителей русского языка, тоже не проходят мимо внимания поэтов. Блестяще обыгрывает их Александр Левин, приведем только начало его стихотворения:

Мы садимся в наш автобус,

Собираемся поехать.

Тут конду́кторы приходят,

А потом кондуктора́.

И конду́кторы нас просят:

«Проездные предъявляйте!»

А кондуктора́ велят нам:

«Оплатите за проезд!»

(«Мы садимся в наш автобус...») 75 .

Знаменательно, что «кондуктора́» (более поздняя и на сегодняшний день просторечная форма) требуют от пассажиров оплаты тоже в неправильной, просторечной форме: «Оплатите за проезд!» (вместо нормативного Оплатите проезд!).

74 Окуджава (1967, с. 19).

75 Левин (2007, с. 204). 
Не минует внимания поэтов и категория падежа. Конечно, можно просто продемонстрировать свои знания из школьной программы, заодно пытаясь оживить внутреннюю форму названий:

Не тронь костра. Так полежи.

Помнишь? В грамматике есть падежи.

Ты - мой родительный. Ты - мой винительный.

Не тронь костра. Так полежи

(Ю. Мориц. «Пять стихотворений о болезни моей матери» $)^{76}$.

Но этим интерес поэтов к данной грамматической категории не ограничивается. Падежная парадигма, с одной стороны, позволяет автору вволю поиграть со словом, поворачивая его к читателю разными гранями, а, с другой стороны, намекает на возможности развития текста: каждая словоформа - это зародыш новой фразы! Поэтому у разных поэтов встречается один и тот же прием:

Тебя не соблазнить ни платьями, ни снедью:

Заезжий музыкант играет на трубе!

Что мир весь рядом с ним, с его горячей медью?..

Судьба, судьбы, судьбе, судьбою, о судьбе...

(Б. Окуджава. «Заезжий музыкант») 77.

Спина подсказывает: нож,

ножа, ножу, ножом, ноже.

В проеме занавеса клин

так разбегается в экран,

как нож обнял бы небеса

(А. Парщиков. «Я жил на поле Полтавской битвы») $)^{78}$.

Сладострастная отрава - золотая Брич-Мулла,

Где чинара притаилась под скалою.

Про тебя жужжит над ухом вечная пчела:

Брич-Мулла,

Брич-Муллы,

Брич-Мулле,

Брич-Муллу,

Брич-Муллою

(Д. Сухарев. «Брич-Мулла»)79.

В конце XX века произошел очередной сдвиг в «фокусировке» языкознания. От структурного анализа и поисков механической системности лингвистическая наука перешла к текстоцентрической парадигме. В центре внимания

76 Мориц (1974, с. 40).

77 Окуджава (1984, с. 229).

78 Парщиков (2014, с. 74).

79 Сухарев (1989, с. 176). 
ученых оказалось общение и соответствующие ему категории: высказывание, текст, дискурс. От номинативной функции интерес сместился к функции коммуникативной; важнейшими понятиями стали смысл, референция, речевая интенция, речевой акт, диалог, креативность, интертекстуальность, языковая игра, метафора, когнитивные механизмы. По-своему это отразилось и в тематике стихотворных произведений. Справедливости ради напомним, что еще великий Пушкин шутил в «Евгении Онегине»:

Как уст румяных без улыбки,

Без грамматической ошибки

Я русской речи не люблю... ${ }^{80}$

Ныне эти строки используются не для оправдания элементарной безграмотности, а в подтверждение того, что речь не должна быть сухой и шаблонной. Значит, нет таких языковых канонов, которые нельзя было бы нарушить в угоду высшим целям - коммуникативным, экспрессивным, эстетическим...

Поэты, с удовольствием балансируя на грани языковой нормы, самостоятельно осуществляют языковые эксперименты. Например, Семен Кирсанов задается целью проверить пределы русского словообразования: от всех ли существительных можно образовать прилагательные (а также другие существительные, наречия и т.д.)? Конечно, гиперболизированное увлечение межчастеречной деривацией выглядит слегка искусственно и отдает тавтологией («каменные камни» и т.п.), но, тем не менее, именно благодаря ей стихотворение приобретает определенную эстетическую ценность:

Между льдами ледяными есть земля еще земней! Деревянные деревья среди каменных камней -

это северней, чем Север, и таежней, чем тайга, там олени по-оленьи смотрят в снежные снега.

Люди там живут как люди с доброй детскостью детей, горя горького не зная

в мире сетчатых сетей.

Под сияющим сияньем домовитые дома,

8 П Пушкин $(1957,5$, с. 68$)$. 
где сплетают кружевницы

кружевные кружева...

$$
(« Д в о и ̆ н о е ~ э х о »)^{81} \text {. }
$$

Поэт может поиграть и с синтаксисом, с порядком слов. Например, может поставить служебное слово - предлог - в абсолютную постпозицию (хотя вообще в русском языке послелоги - вроде радu - большая редкость). Но читатель легко «проглатывает» эту неправильность, более того - чувствует некоторое удовлетворение от того, что идет навстречу поэту в своем ощущении речевой свободы:

А я, собирая свой ранец,

жуя на ходу бутерброд,

пускаюсь в немыслимый танец

известную музыку под

(Б. Рыжий. «Еще не погаснет жемчужин...») $)^{82}$.

Булат Окуджава наглядно демонстрирует правило, которое ни в какой грамматике не формулируется, но составляет пресуппозицию для любого человека: содержание придаточного предложения не должно повторять содержания главного:

Я никогда не витал, не витал

В облаках, в которых я не витал,

и никогда не видал, не видал

городов, которых я не видал.

И никогда не лепил, не лепил

кувшин, который я не лепил,

и никогда не любил, не любил

женщин, которых я не любил...

(«Я никогда не витал, не витал...») $)^{83}$.

Олег Григорьев, креативный и непредсказуемый в своих творениях, экспериментирует в том числе и с синтаксисом. В следующем катрене (без названия) всего три участника: дом, люди и кастрюли. Но поэт «выжимает» из этого набора предметов максимум возможных отношений (аналогичный прием свойствен поэзии Генриха Сапгира). И такая сумма преобразований, своего рода грамматическая чехарда, завораживает читателя, а заодно напоминает ему о свободе лексического заполнения заданных синтаксических позиций (трансформацией в строгом смысле слова эти преобразования не являются):

Дом, полный криков людей и звона кастрюль.

Звон кастрюль, полный домов и крика людей.

81 Кирсанов $(1976,4$, с. 84$)$.

82 Рыжий (1997).

83 Окуджава $(1967$, с. 12$)$. 
Звон людей, полный домов и крика кастрюль. Дом кастрюль, полный звона людей ${ }^{84}$.

Лев Лосев, будто специально для учебного пособия, демонстрирует особенности словоизменения группы русских существительных на -мя: племя, стремя, бремя, знамя... Вот как выглядит это в стихах:

Разлиплись. Теперь заработало время, чтобы из семени вывелось бремя, чтобы втемяшилось в новое племя: пламя на знамени и - в стремена! («Русская ночь») $)^{85}$.

А Юрий Казарин, как будто предчувствуя позднейшие политические события, подбирает такие эпитеты к слову Крым, которые заставляют читателя вспомнить правило об однородных и неоднородных определениях:

Светом полна слепота человечья.

Белый ягненок бодает кошму.

Знаешь, у всех заломило предплечье

в греческом русском татарском Крыму

(«Пасмурный день. Средиземная скука...») ${ }^{86}$.

Трудно найти грамматическое правило, которое не могло бы быть обыграно в поэтическом тексте. Обладая значительной степенью речевой свободы, поэт легко гиперболизирует тот или иной факт языковой системы. Причем в текстах современных авторов широко используются и узкоспециальные лингвистические термины - такие как инфинитив или билабиальный ${ }^{87}$. Это - активизация метаязыковой функции в сознании человека, а для поэта - способ привлечь внимание к инструменту своего творчества. Известно, в частности, пристрастие, которое испытывал к терминам Иосиф Бродский - особенно к терминам математическим и лингвистическим ${ }^{88}$. Среди последних встречаются такие, как: подлежащее, сказуемое, существительное, глагол, суффикс, множественное число, имя собственное, личное местоимение, несовершенный вид, многоточие и многие другие. Приведем в качестве иллюстраций две цитаты из цикла «Часть речи»:

Одичавшее сердце все еще бьется за два.

Каждый охотник знает, где сидят фазаны -

в лужице под лежачим.

84 Григорьев (2015, с. 160).

85 Лосев $(1996$, с. 6$)$.

86 Казарин (2006а, с. 36).

87 Зубова (200о, с. 21-27); (Зубова 2010, с. 219-223 и др.).

88 Мечковская (2001); Ахапкин (2002). 
За сегодняшним днем стоит неподвижно завтра, как сказуемое за подлежащим... ${ }^{89}$.

...Жизнь, которой,

как дареной вещи, не смотрят в пасть, обнажает зубы при каждой встрече.

От всего человека вам остается часть

речи. Часть речи вообще. Часть речи ${ }^{90}$.

Очевидно, это не случайная дань школьной программе по русскому языку, но - концептуальная черта, отражающая авторское восприятие мира вместе с соответствующим метаязыком. Можно согласиться с Н.А. Николиной, пишущей:

Поэтические тексты с течением времени становятся все более «лингвоцентричными», при этом языковые темы и образы теряют в них периферийный, маргинальный характер, присущий им раньше. В современной поэтической речи существенно расширяется состав сигналов метаязыковой рефлексии, прежде всего лингвистических терминов, которые все чаще выступают в текстообразующей функции ${ }^{91}$.

Интерес к языку вообще (а, в частности, к языку науки, языку улицы, языку предыдущих текстов и т.д.) прямо соотносится с коммуникативными проблемами, которые в конце XX века уже с очевидностью ставятся во главу угла. Изменения в объекте чувствований и размышлений требуют новых средств выражения, в том числе и научных терминов:

Коммуникативная функция слова,

Она, если в ней разобраться толково,

Кому - позитивная функция слова,

Кому - негативная функция слова

(Д.Сухарев. «К вопросу о коммуникативной функции слова»)92.

И еще цитата в тему, соединяющая неоклассицизм с постмодернизмом:

Словесный сад.

В нем статуи имен.

Цветы цитат

Произрастают в нем.

В нем как стекло -

проточных мыслей пруд.

Сам Буало

одобрил бы сей труд.

89 Бродский (1992, 1, с. 315).

90 Бродский (1992, 1, с. 327).

91 Николина (2009, с. 353).

92 Сухарев (1989, с. 231). 
Вот Музы храм.

Вот сердца Монплезир.

Но не бежать ли нам

в безумный мир?

(В. Британишский. «Словесный сад...»)93.

Безумный мир, в который собирается бежать поэт, - это, в отличие от языкового Зазеркалья (цветущего сада слов), - реальность обыденной жизни, мир обесцененных понятий и обессмысленных терминов.

Важной частью коммуникации является налаживание контакта: приветствия, прощания, поздравления, соболезнования, разнообразные словесные «поглаживания» и «уколы»... В лингвистике принято выделять отдельную функцию языка - контактоустанавливающую, или фатическую. Она обеспечивается главным образом набором стандартных речевых формул (клише). В стихотворении Е. Винокурова «Пустой обряд» как раз и говорится о том, что за кажущимся пустым фатическим общением скрываются серьезные смыслы:

Суровой повседневности обряд -

Вопрос: «Как жизнь?» И тут по ритуалу:

«Да ничего». - «Ну будь...» - «Вот так-то, брат...»

Но человек начнет мало-помалу

Рассказывать:

«Такие, брат, дела... -

Сначала, так, с неловкостью, несмело, -

Жена на той неделе умерла,

Дочь что-то, между прочим, заболела.

Зашел бы, как-никак...»

Я на него

Гляжу. Он козырек надвинул. «Э, он плачет...»

...Спроси: «Как жизнь?», ответит: «Ничего...»

Но это ничего еще не значит ${ }^{94}$.

Однако выбор конкретного «ситуационно привязанного высказывания»95 с целью налаживания контакта подразумевает учет личности адресата. Прежде всего имеется в виду, конечно, ситуация разговорной речи, с конкретным, нередко хорошо знакомым собеседником. Совершенно по-иному обстоит дело в публичном общении. Но и здесь способ обращения к аудитории, оформление печатного текста, посвящение на книге стихов и т.п. все это играет свою прагматическую роль. Говоря словами М.М. Бахтина,

Высказывание имеет и автора, и адресата. Этот адресат может быть непосредственным участником-собеседником бытового диалога, может быть диффе-

93 Британишский $(1985$, с. 43-44).

94 Винокуров (1965, с. 19).

95 Kecskes (2010, p. 2892-2894). 
ренцированным коллективом специалистов какой-нибудь специальной области культурного общения, может быть более или менее дифференцированной публикой, народом, современниками, единомышленниками, противниками и врагами, подчиненным, начальником, низшим, высшим, близким, чужим и т.п.; он может быть и совершенно неопределенным, неконкретизованным другим...96.

Чем определеннее адресат, тем больше интерес и расположенность говорящего к нему (для этого существует особое понятие в психологии - эмпатия), тем удачнее подбор соответствующих средств выражения, тем явственней реакция собеседника - все это входит в объект социолингвистики. Поэт же замечает свои детали:

При встречах мы здоровались не часто.

Ребячий мир на взрослый не похож.

«Что я нашел!» звучало вместо «Здравствуй!»

«Пойдем на речку!» вместо «Как живешь?»

(В. Берестов. «Три школьных возраста»)97.

Последние строки характеризуют, очевидно, особенности детского фатического общения. А вот пример иной ситуации: солдатик на пароходе пытается немудреной песней привлечь к себе внимание и получить ответную реакцию:

Страшно, если слушать не желают.

Страшно, если слушать начинают.

Вдруг вся песня, в целом-то, мелка,

вдруг в ней все ничтожно будет, кроме

этого мучительного, с кровью:

«Граждане, послушайте меня...»?!

(Е. Евтушенко. «Граждане, послушайте меня...») $)^{98}$.

В последние годы поэзия приблизилась и к психолингвистической проблематике. Объектом ее становятся механизмы внутренней речи, позволяющие говорящему строить такие высказывания, которые могут и должны быть адекватно восприняты и поняты слушающим. Говоря по-другому, поэт старается отразить сугубо творческие аспекты порождения текста, которые только еще начинают профессионально изучаться филологами.

Владимир Маяковский в свое время подробно описал процесс художественного творчества в статье «Как делать стихи». Он, в частности, обратил там внимание на то, что подбор вариантов значимых языковых единиц (слов, конструкций) накладывается на уже выбранную ритмическую основу:

96 Бахтин (1979, с. 275$)$.

97 Берестов $(1977$, с. 49$)$.

98 Евтушенко (1980, 1, с. 299). 
Старание организовать движение, организовать звуки вокруг себя, находя ихний характер, ихние особенности, это одна из главных постоянных поэтических работ - ритмические заготовки. Я не знаю, существует ли ритм вне меня, или только во мне, скорей всего - во мне 99 .

Эти наблюдения имеют отношение и к общей теории речепорождения. Выше уже шла речь о роли фонетических связей и о взаимодействии элементов разных языковых уровней в процессе порождения текста. Но вот свежий пример. Стихотворение Давида Самойлова «Черновик» - очередная попытка раскрыть кухню поэтической работы и, в частности, выявить, эксплицировать ход поиска нужного слова. Конечно, в каком-то смысле это имитация и упрощение реальных процессов, протекающих в сознании говорящего, но всё же попытка весьма ценная в лингвистическом плане.

Весна! (Зачеркнуто) Прекрасный март...

(Зачеркнуто) Голубоглазый март...

(Зачеркнуто) Весна вошла в азарт...

(Оставлено) Каракули (Та-ра-та)...

Читает март... Каракули сирени

Читает (Прочерк), как стихотворенье.

Весна вошла в азарт!

Каракули сирени

Читает (Прочерк) март

(Тара) стихотворенье.

Хоть ритмика строга,

Но вот она строфа:

Весна вошла в азарт!

Каракули сирени

Голубоглазый март

Читает в упоенье!!оo

Выбранный с самого начала ямбический размер постепенно заполняется нужными словами. И в результате, при тщательном отборе лексики, получается довольно сложный образ начала весны: каждая строка содержит метафору.

Говоря о процессе порождения стихотворного текста, нельзя еще раз не отметить, что поэт сплошь и рядом идет «на поводу у слов». Это значит - уже найденные лексемы своими ассоциативными связями подталкивают автора к выбору очередного элемента, корректируют авторскую стратегию. Вместе с тем, можно сказать, что таким образом обнаружива-

99 Маяковский (1960, 1, с. 473).

100 Самойлов (1992, с. 44). 
ется и эксплицируется структура семантических связей в нашем сознании: поэт как бы ставит над собой психолингвистический эксперимент. Рассмотрим несколько разнотипных примеров.

Но не пленить тебя ни пирамидой

фаянсовой давно не мытой

посуды в раковине, ни палаткой

сахары сладкой

(И. Бродский. «Муха») ${ }^{101}$.

Поэт разговаривает с мухой. Банальная ситуация: на кухне в раковине немытая посуда. Но вид этой посуды (пирамида) напоминает геометрическую форму египетских пирамид. Отсюда перекидывается мысленный мостик к пустыне Сахара. В итоге вместо существительного мужского рода сахар появляется «сахара сладкая».

Следующий пример.

Там на заход валетик желторотый,

Там на отбой четыре короля,

Там козырями черви под колодой,

Там за окном летучая земля

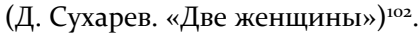

Тоже простая ситуация: в вагоне играют в карты. Козыри - черви. Но название этой масти наводит на мысль о червях, которые живут в земле (а земля между тем пролетает за окном). Поддерживается же эта фоновая связь словосочетанием под колодой (колода ведь это не только «стопка карт», но еще и «обрубок бревна»). Постоянная смена двух смысловых планов («карточная игра» и «бренность существования») основана на игре слов.

Третий пример.

...От моего чуда -

До твоего чада,

От моего худа -

До твоего ада,

От моего Клина -

До твоего Крыма,

От моего сына -

До твоего сына,

От твоего гроба -

До моего хлеба,

От моего нёба -

До твоего неба,

От твоей соли -

До моей силы,

101 Бродский (1992, 2, с.135).

102 Сухарев (1989, с. 114). 
От твоей боли -

До моей были...

(В. Долина. «От твоего дома...») $)^{103}$.

Изначально задана не только синтаксическая структура всего стихотворения (базирующаяся на антитезе), но и фонетическое сходство противопоставляемых понятий (чудо и чадо и т.д.). На этом фоне повтор одной и той же лексемы (от моего сына - до твоего сына) даже режет глаз, вызывая эффект обманутого ожидания.

Четвертый пример.

Не сочти за труд (Май. Мир),

Отпиши письмо на край земли.

Где-то комиссар, где-то эмир -

Все следы пески замели

(М. Мерман. «Не сочти за труд...») $)^{104}$.

Просьба, основанная на устойчивом выражении (не) счесть за труд, накладывается у автора на стереотипный лозунг советских времен: Труд. Mup. Май (использовавшийся на демонстрациях 1 Мая). Избавиться от этого словесного наследия очень трудно, и ассоциации непроизвольно прорываются в стих.

У Александра Кушнера есть специальное стихотворение, посвященное роли вводных слов в процессе порождения текста. Для поэта вводные слова - текстообразующие элементы, облегчающие говорящему его деятельность:

Меня, как всех, не раз, не два

Спасали вводные слова,

И чаще прочих среди них

Слова «во-первых», «во-вторых».

Они, начав издалека,

Давали повод не спеша

Собраться с мыслями, пока

Не знаю где была душа

(«Вводные слова») ${ }^{105}$.

А стихотворение того же Кушнера «Голос» - это просто готовый параграф пособия по нейролингвистике. Во второй половине XX века была экспериментальным способом подтверждена функциональная асимметрия полушарий головного мозга. Когда испытуемому блокировали работу левого полушария, то с помощью правого он мог создать грубый обобщенный образ структуры текста. А при «выключенном» правом полушарии, наоборот, текст анализировался с помощью тонких формально-логических

103 Долина (1981).

104 Мерман (2007, с. 136).

105 Кушнер (1986, с. 181). 
операций. Эти результаты, полученные физиологами и нейролингвистами, давали основания языковедам говорить о существовании «двух грамматик», локализованных в разных отделах головного мозга ${ }^{106}$. Как же данная проблема представлена в стихотворении Кушнера? Приведем оттуда несколько отрывков:

Мозг ночью спит, как сад в безветрии.

Клонилась речь на семинаре

К функциональной асимметрии

Его бугристых полушарий. [...]

В пространстве левом - опыт умственный

Прохладный, дышащий безликостью,

В пространстве правом - вещный, чувственный.

С шероховатостью и выпуклостью! [...]

Пространство левое, абстрактное,

Стремящееся в неизвестное;

Пространство правое, обратное,

Всегда заполненное, тесное...

(«Мозг ночью спит...») ${ }^{107}$.

Перед нами, можно сказать, «наука, положенная на музыку»... Но добавим, что это стихотворение Кушнера вызвало некое подобие ревности у другого уже упоминавшегося поэта - Дмитрия Сухарева (между прочим, доктора биологических наук, как раз занимающегося нейробиологическими исследованиями). У него та же самая проблематика предстает в ином свете; глубинный смысл - не следует профану касаться специальных тем.

Я ищу у амфиокса

Мозга клеточный исток,

Я проникся, я увлекся -

Вот он, свернутый листок!

Кушнер рядышком шныряет,

Миг - и тянется к листку,

И куда его швыряет? -

В набежавшую строку

(«Проклинание Кушнера») $)^{108}$.

За языковым озорством, иронией и интертекстуальностью (ср.: «И за борт ее бросает в набежавшую волну» - из песни о Стеньке Разине) скрывается интерес к вполне серьезной научной проблематике. Поэт не просто ее популяризирует, но высказывает к ней свое отношение, выстраивает ее художественный образ.

106 Черниговская, Деглин (1984); Сахарный (1994, с. 9-14).

107 Кушнер (1981, с. 158-159).

108 Сухарев $(1989$, с. 249$)$. 
В сумме у нас получается нечто вроде хрестоматии, составленной из цитат на тему «лингвистическая рефлексия русских поэтов». Хотя это, конечно, лишь малая толика того выраженного отношения к языку, которое можно найти в стихотворных текстах. За пределами нашего внимания остались замечательные русские поэты - А.П. Сумароков и Ф.И. Тютчев, Велимир Хлебников и Саша Черный, Николай Рубцов и Олег Чухонцев... Но и тот материал, который был проанализирован, показывает исключительную ценность поэзии не только как объекта, но и как источника лингвистических знаний.

Нельзя, конечно, сказать, что в этих текстах реализуется некая цельная научная концепция. Художник слова, в конце концов, остается художником слова. Но поражает лингвистическая интуиция поэтов, их способность заметить и использовать самые разные, даже малозначимые, особенности средства общения. Эти всеохватные наблюдения и заключения касаются как современного состояния русского языка, так и его исторического развития, они дополняют наши представления о функциях языка - когнитивной, коммуникативной, номинативной, экспрессивной, фатической и др. 


\section{Глава 2. Лингвист как поэт: переключение кодов или смена парадигмы? (анализ поэтического творчества профессиональных языковедов)}

Человеку, занимающемуся лингвистикой (научному работнику или вузовскому преподавателю), иногда оказывается недостаточно своего профессионального поля деятельности, и он ищет иные возможности проявить свое знание и понимание языка. В частности, у него может хватить смелости и творческих потенций для литературного творчества.

Вообще известны примеры, когда реальная личность совмещала в себе черты исследователя и писателя. Может быть, самый яркий пример в гуманитарной сфере - это итальянец Умберто Эко, известный специалистам своими трудами в области семиотики и философии, а широкой публике - романами «Имя Розы», «Маятник Фуко» и др. Есть достойные образцы и в истории русской культуры: Ю.Н. Тынянов, В.Б. Шкловский и др. Но сам собою возникает вопрос: может ли человек, знающий законы искусства (и языка) «извне», рационально, одновременно пользоваться ими «изнутри», как творец - в значительной степени иррационально, по наитию? И что побеждает в таком случае: знание и расчет или чувства и интуиция креатива? По-видимому, в разных случаях, применительно к разным личностям, можно говорить о доминировании того или иного начала - научного, аналитического, или творческого, направленного на синтез нового произведения. Скажем, если брать современную Россию, то, с нашей точки зрения, профессор Уральского федерального университета Ю.В. Казарин - «больше поэт», чем лингвист: у него вышло уже более десятка поэтических сборников. Укажем здесь только некоторые из них $^{109}$. Хотя дело тут, конечно, не столько в количестве публикаций, сколько в общем впечатлении от самого стиля мышления и чувствования.

В данном случае мы поставим перед собой более конкретную задачу: проанализировать поэтическое творчество ряда наших современников, зарекомендовавших себя как языковеды. Критерием профессиональной квалификации будет для нас ученая степень доктора филологических наук, а проявлением литературного творчества - опубликованный сборник стихов (или несколько таковых). В поле нашего зрения попадают стихотворные произведения В.Г. Адмони, М.В. Панова, Б.И. Осипова, В.А. Карпова, В.М. Мокиенко, Л.В. Зубовой, Л.О. Чернейко.

Понятно, что во всех интересующих нас случаях человеком руководят некоторые внутренние посылы и интенции - сформулируем это как желание в стихотворной форме высказать то, что невозможно выразить

109 Казарин (1991); Казарин (2002); Казарин (2006а); Казарин (2014а) и др. 
иным способом. Л.В. Зубова прямо пишет об этом: «Чтобы в стихах говорилось то, что нельзя сказать иначе» ${ }^{10}$. Но нас интересует: можно ли у всех этих авторов, во всех проанализированных ниже сборниках, найти какие-то общие черты? Накладывают ли лингвистическая квалификация и соответствующий опыт отпечаток на литературное творчество, обусловливают ли какие-то особенности последнего? В.М. Мокиенко в предисловии к своему сборнику «Ростки безвременья» утверждает: «...Стихи поэтов-филологов имеют одну общую особенность. Они несут отпечаток филологического профессионализма, т.е. специального литературнолингвистического интереса своих авторов. В отличие от поэтов-лириков, «не испорченных» филологическими изысками «чужих» слов и текстов, поэт-филолог невольно более зависим от объекта своих научных занятий и потому, быть может, - более подражателен. Нередко [бывает,] что и те, о ком он пишет в своих стихах, - не какое-либо конкретное событие или лицо из его собственного жизненного опыта, а - реминисценция прочитанного, увиденного, услышанного»" ${ }^{\text {․ }}$ Так ли это в действительности? Чтобы проверить данный тезис, обратимся к текстам.

Самый необычный поэт среди русских лингвистов XX века - это Михаил Викторович Панов. Речь пойдет о двух его сборниках - «Тишина. Снег» (вышедшем еще при жизни автора, в 1998 году) и «Олени навстречу» (подготовленном к печати его учениками и коллегами в 2001). Панов принадлежит к плеяде крупнейших русских лингвистов, это безусловный авторитет в области фонологии и морфологии русского языка. Велики и его заслуги в грамматике, и его организационная роль в подготовке новаторской 4-томной монографии «Русский язык и советское общество» (1968).

Михаил Викторович прошел всю Великую Отечественную войну (ушел на фронт добровольцем). Его научная биография тоже была непростая, но слушатели его лекций всегда платили ученому признательностью и любовью.

В поэзии Панов - смелый экспериментатор. Подавляющее большинство его поэтических произведений написано свободным стихом - верлибром, без рифм и определенного размера. Фактически, по ведомству поэзии их определяет только образная система да разбивка на строки ${ }^{12}$. В прижизненно изданном сборнике мы встречаем такое признание (стихотворение «Ночью»):

Думаю о судьбе русского свободного стиха:

будущее - за ним. И совсем не бескрылый,

110 Зубова (2012, с. 5).

111 Мокиенко (1997, с. 3-4).

112 Илюшин (2011, с. 93-95). 
не безвольный, вранье: это стих глубокого дыханья, яркости, крутизны. Блок давно уже это открыл"13.

Если юношеские стихи М.В. Панова традиционны по своей тематике (природа, жизнь, любовь), то начавшаяся война в корне все меняет: в стихах появляются драматические или трагические сюжеты. Цитата из того же сборника:

Дневниковые записи этих дней

Гноем полны и кровью

$$
\text { («После боя») })^{14} \text {. }
$$

Приведем также для подтверждения полностью небольшое стихотворение, не имеющее названия.

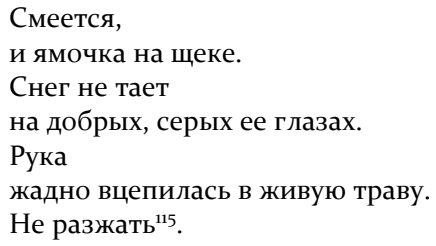

Никаких особых поэтических приемов, вроде аллитерации, внутренней рифмы или кольцевой структуры, Панов в этих стихах не использует. Не обращается он и к филологическим проблемам: иные темы занимают его сознание, его душу.

Во второй книге стихов, вышедшей уже посмертно, «Олени навстречу» ${ }^{16}$, подбор текстов более разнообразный и представление о внутреннем мире ученого-поэта меняется. Самый неожиданный здесь раздел «Басни в растопыр», в том числе обличающие и тогдашних советских чиновников от литературы - Кочетова, Грибачева, Ермилова и др., и «Всероссийского Чинушу»... Удивительно, какой политической зрелостью и прозорливостью обладал ученый!

В этих текстах Панов-поэт дает волю Панову-лингвисту. Лучшее свидетельство тому - подборка стихов, посвященная классику языкознания И.А. Бодуэну де Куртенэ. Приведем одно из них: это, можно сказать, страница учебника фонологии, положенная на музыку.

Люблю Бодуэна

Может ли быть: человек и веник - одно?

То же самое? Совпадают? Одна сущность?

Не различить?

113 Панов (1998, с. 6о).

114 Панов (1998, с. 53).

115 Панов (1998, с. 71).

116 Панов (2001). 
В сказке все бывает.

И в языке. Две единицы,

совсем разные, как веник и человек, могут быть - одно.

И люди их не различают,

в одном видят другое:

если они функционально равны,

работают в разные смены,

но в одинаковой должности.

Называется: фонема.

Ряд позиционно чередовательных звуков,

самых разных, непохожих.

А говорители думают: это все одно,

неразличимое то же.

Это волшебство в языке открыл Бодуэн ${ }^{117}$.

Замечательно и стихотворение под названием «Из учебника по развитию речи»:

Выпишите:

Эта шапка мне

велика

мала

как раз

Это пальто мне

велико

мало

широко

узко

как раз

Эти туфли мне

велики

малы

тесны

как раз

Этот мир,

воющий радиоволнами,

лгущий светом,

пьянящий счастливым смехом женщин,

бомбой испаряющий города,

и зеленый от трав,

и красный от пожаров,

и тихий от книг, -

этот мир мне

велик

мал

117 Панов (2001, с. 43). 
тесен как раз ${ }^{118}$.

От шаблонного дидактического задания перекидывается мостик к глубокому философскому обобщению. Окружающий мир - чрезвычайно многообразен, но и отношение к нему не укладывается в рамки какого-то регламента - в каждом случае человек выбирает его сам.

Уже в первой из упомянутых книг представлены словообразовательные окказионализмы вроде кудахт или бульком (существительные), ольдевший (причастие) и др. Во второй же мы встречаем существительные кругли (о слезах), турумбуку, сырь, наречия хлипко и тифозненько, прилагательные мулямый и хлюплый и т.п.

Будучи мастером игры со словом и прекрасно понимая «целебное действие звуков», Панов придумывает в своих стихах фантастические имена вроде Цляма Киль, Уругула, Aаann, Антл, Фрыля и Брыля и др.; междометия вроде чимбурляк! урфяк! нырь! пырь! лизь! и т.п. Все это развитие идей звукосимволизма, продолжение творческих поисков А. Крученых и других русских футуристов. Приведем одну иллюстрацию из сборника «Олени навстречу».

В честь А. Е. Крученых

Ль?

Фус.

Дыш? Фпак.

Шузипатра вакха.

Чш?

Хт.

Ульс? Фльдик.

Упферлиди кумба.

Ц.

Ц.

Ц.

Ц.

Гвр - дзр ${ }^{19}$.

А помещенное здесь же стихотворение «Люди кррая» - это гимн вообе всем новаторам и первопроходцам в искусстве и науке. Среди них находится место не только Алексею Крученых, но и М.Н. Петерсону, создателю «ультра-формальной» грамматики русского языка.

Кстати, и название сборника «Олени навстречу» по-своему отражает наблюдения ученого над закономерностями развития русского языка. Еще

118 Панов (2001, с. 8).

119 Панов (2001, с. 23). 
в начале XX века наречие в атрибутивной позиции резало языковедам глаз и слух (А.М. Пешковский считал словосочетания типа окно напротив «совершенно исключительными случаями» $\left.{ }^{120}\right)$. Для Панова же олени навстречу - это речевая реальность, основанная на правилах всемогущей синтаксической компрессии.

Встречаются в сборнике и яркие примеры метафоры. Так, стихотворение, посвященное великому русскому биологу Н.И. Вавилову, начинается следующими строками:

Ехал ученый на бричке. По пестрой Америке ехал.

Думал, ботаникой мозга раскинув: где проживают толпы

Сытых домашних растений? Открыл. Там и здесь... ${ }^{121}$.

«Ботаника мозга» и «сытые растения» (которые «проживают толпами») яркие поэтические образы, созданные языковыми средствами. Ботаника выбирается здесь как символ «наиболее систематизированной» науки, сытость - как проявление благополучия, а толпа - как символ множественности. По Э. МакКормаку, это образцы «передающей» метафоры ${ }^{122}$ - разового сдвига в концептуализации (без претензий на фундаментальное обобщение); но именно они характерны для поэзии как таковой.

В небольшой шутливой поэме «Дядя Федя и тетя Мотя», квалифицированной автором как «балаган», Панов позволяет себе поиграть даже с каноническими падежными формами:

Сюртука он надевал

и подвязки подвязал [...]

Чемоданчика он брал

и ногами побежал.

В «Волгу» дядя ловко сел, он трамвая не умел [...]

Федя потреблял котлет, не гнушался винегрет,

в дегустации мадер

он живительный пример ${ }^{123}$.

Здесь можно усмотреть и традиции русского фольклора (частушка, лубочные тексты, скоморохи, балаганчик), и влияние одесского юмористического колорита. Культура смехового «низа» не очень почтительно относится к каким бы то ни было правилам, в том числе и языковым.

120 Пешковский (1956, с. 339).

121 Панов (2001, с. 20).

122 МакКормак (1990, с. 382).

123 Панов (2001, с. 28-30). 
Совершенно неожиданна для читателя и включенная в книгу «Олени навстречу» романтико-фантастическая поэма «Одна» - о спасении плененной девушки в экзотических краях. Завершает книгу подборка «образных впечатлений, которые возникают у автора при чтении русских поэтов». Знаменательно, что наряду с признанными классиками (Ломоносов, Брюсов, Андрей Белый, Ахматова...) сюда попали и поэты, на сегодняшний день полузабытые, вроде Василиска Гнедова, Валентина Горянского или Дмитрия Петровского.

Несомненно, творчество Михаила Викторовича Панова - уникально. В его научных публикациях интонации разговорной речи окрашиваются искорками поэтического озарения. А в его стихах, при всей их формальной вольности (порою даже озорстве), то и дело обнаруживается внимательный взгляд исследователя. Широкий филологический кругозор, независимость и остроумие обусловливают здесь переплетение поэтических образов с лингвистическими наблюдениями.

Владимир Григорьевич Адмони - петербургский германист с мировой славой, автор ставшей уже классической теоретической грамматики немецкого языка ${ }^{124}$, специалист по Г. Ибсену и Р.-М. Рильке, блестящий переводчик с немецкого. Но, как отмечал в Послесловии к его сборнику стихов академик Д.С. Лихачев, Адмони «считает себя прежде всего поэтом. Именно поэзия в значительной степени определила собой и его научные интересы, и интересы его как переводчика» ${ }^{125}$. Сам Владимир Григорьевич называл поэзию «разовым чудом» и «заветным вздором».

Стихотворный сборник «Из долготы дней» ${ }^{126}$ отражает весь период сознательной жизни ученого: с 1925 по 1983 год. За это время личность несколько раз духовно перестраивается. Но сквозные темы стихотворений В.Г. Адмони - это природа, любовь, Петербург и Нева... С 1974 года к ним прибавляется скорбь по ушедшему самому близкому человеку.

Лингвистические понятия и термины в стихах В.Г. Адмони почти не встречаются (за исключением названий знаков препинания, да еще общих понятий «слово», «слог», «речь»):

Нет, я не верю в немоту

Души, извечно человечьей.

Ей слово - словно весть о свете,

Вторгающемся в темноту.

Ведь слово - это путь и даль.

И приближенье к этой дали.

Прикосновение страданий.

И разделенная печаль.

124 Admoni (1986).

125 Лихачев (1984, с. 82).

126 Адмони (1984). 
И чем сильней сердца людей,

Тем тверже их земные речи.

И только им дано ответить

Всем странникам немых путей

(«Нет, я не верю в немоту...») $)^{127}$.

Зато литературоведческая тематика представлена в сборнике широко: это сюжеты Пушкина, Достоевского, Шекспира, Гете... Среди имен собственных - Ариадна, Орфей, Эвридика, Гамлет, Лаэрт, Фортинбрас, Вертер, граф Нулин, князь Мышкин и т.д. - тут, действительно, филологическое образование и профессиональные интересы автора дают себя знать.

Отражена в стихах и биография ученого. Войну он провел на Ленинградском фронте. Стихотворение без названия:

Черная кровь на запекшейся ране,

В ссохшейся коже колючий скелет.

Красное солнце в морозном тумане.

Мглистые сумерки, желтый рассвет.

Это безмерной зимы Ленинграда

Гулкая, горькая слава взошла.

И навсегда нам досталась награда -

Память ночная про эти дела ${ }^{128}$.

Характерной особенностью стихотворного творчества В.Г. Адмони является некоторая свобода (или случайность) в использовании предлогов и падежных форм. Это вообще далеко не новая черта в русской поэзии, но тут она обращает на себя внимание:

Это все ведь тоска о себе, о себе,

Это все ведь тоска об ушедшей тоске,

О влюбленности давней, далекой весной,

И о пламенных окнах в закат городской ${ }^{129}$.

Ветра пенистую волю

Встретим лодкой в гребень волн... ${ }^{130}$.

И в мягких иглах подымались ели,

И расцветали нежные цветы... ${ }^{131}$.

И под свистом чужого простора,

В брызгах, падающих пеленой,

127 Адмони (1984, с. 75).

128 Адмони (1984, с. 18).

129 Адмони (1984, с. 8).

130 Адмони (1984, с. 13).

131 Адмони (1984, с. 23). 
Оставался последней опорой

Теплый, теплый песок подо мной ${ }^{132}$.

Я каждой встречей заново томим

В податливости этой неослабной ${ }^{133}$.

Вообще синтаксическим связям в стихотворениях свойственно ослабевать: в какой-то степени эти функции принимает на себя строка, а в какой-то мере - межсловные ассоциации. Поэтому выбор падежных и предложно-падежных форм не играет здесь такой роли, как в прозаических текстах. Приведенные строки это подтверждают.

В стихах Адмони используются общепринятые стихотворные размеры, но очень часто наблюдается перебив ритма: добавление или пропуск слога в строке, например:

Все же вечности можно верить -

Нам достанет ее навек.

Снова крупнозернистым и серым

Стал в соседнем садике снег

(«Все же вечности можно верить...») $)^{134}$.

Из кривизны лет,

Из долготы дней,

Из-под опущенных век

Взгляд твой еще нежней

(Без названия) $)^{135}$.

Глубина эмоциональных всплесков в сочетании с богатым версификаторским опытом приводит автора подчас к появлению сложно выстроенных стихотворений, напоминающих по своей форме «стиль плетения словес» в русской литературе. В риторике есть для этого специальный термин: амплификация. Так простой факт - лежащий за окном снег - порождает следующую словесную архитектонику:

В черных окнах домов отражается снежное поле,

Словно новое снежное поле легло за стеной -

Но со снегом ночным мне давно уже надо поспорить

Или снегу ночному пора бы поспорить со мной.

Потому что ему нашу память сровнять не дано.

Не дано превратить ее в ровное снежное поле.

\footnotetext{
132 Адмони (1984, с. 45).

133 Адмони (1984, с. 72).

134 Адмони (1984, с. 33).

135 Адмони (1984, с. 77).
} 
Потому что со снегом ночным мне поспорить хотелось давно.

Или снегу ночному со мною хотелось поспорить

(Без названия) $)^{136}$.

Приведем еще превосходный, почти афористический, образец хиазма:

Я найду твою душу в тиши.

Я верну тебе силу души.

Дам и твердость - да будешь горда.

Дам и гордость - да будешь тверда

(«Бедовать не позволю тебе...») $)^{137}$.

Характерны для поэтического творчества Владимира Григорьевича метафоры: степенные хлопочут воробьи (с. 29), автобусная тряска дней (с. 38), на Неве льдины вянут (с. 68) и т.п. Приведем несколько развернутых примеров:

И как тут приветить, заметить

Суставы склоненных кустов...138

Мы все-таки любовь не застолбили,

Не обнесли заборами ее... ${ }^{139}$

И тарелкою белою, битой

Небо висло над каждым из нас... ${ }^{10}$

Встречаются в стихах В.Г. Адмони и примеры аллитерации (грань гранита, замедленная земля, сквозь блеклые окна - солнечный блик и т.п.), и повтор корневой морфемы (крайние края, тихая тишь, любовь навек запечатлев любовью и т.п.), и кольцевая структура, и синтаксический параллелизм строк - это все типичные для классической русской поэзии технические приемы. Но, если не быть знакомым с личностью автора, то определить по стихам, что их написал лингвист, практически невозможно.

Борис Иванович Осипов, профессор Омского университета, - известный в России специалист по орфографии, истории русского письма, фонетике и разговорной речи, редактор «Словаря современного русского города» (2003). Его перу принадлежат два стихотворных сборника: «Про политику. Стихи с примечаниями» (2012) и «Про женщин» (2014). Мы здесь проанализируем второй из них.

136 Адмони (1984, с. 42).

137 Адмони $(1984$, с. 68$)$.

138 Адмони $(1984$, с. 40).

139 Адмони (1984, с. 44).

140 Адмони (1984, с. 45). 
В соответствии с названием, основная тема стихотворений - любовь к женщине. Ранние стихи полны юношеского энтузиазма; природа выступает в качестве постоянного фона человеческих отношений. Приведем полностью одно стихотворение без названия:

Пойдем с тобой в луга холодные,

Где хлещут лес дожди осенние.

Быть может, там, от пут свободная,

Любовь найдет себе спасение.

Быть может, там - вдали от взоров -

Любых: докучливых, участливых -

Взаимных избежим укоров

И будем хоть минуту счастливы.

И за одно прикосновение

И за улыбку губ любимых

Пусть хлещут нас дожди осенние

И ветры голосят о зимах ${ }^{141}$.

Ощутимо в стихах Осипова гендерное начало, вплоть до плохо скрытого эротизма:

Когда ты отдавалась власти

Большой ли, малой ли, но страсти,

Шептала ты во тьме ночной:

«Ты мой! Ты мой!»

Но никогда не слышал я,

Чтоб ты шепнула: «Я твоя!»

(Без названия $)^{142}$.

С Вами мы любовь не крутим -

Что ж и въяве, и во сне

Ваши маленькие груди

Не дают покоя мне?

Ваши губки, Ваши зубки

Вашей талии изгиб,

Макси-джинсы, мини-юбки

Шепчут мне: «Погиб, погиб!»...

(Без названия) $)^{143}$.

141 Осипов (2014, с. 10).

142 Осипов (2014, с. 17).

143 Осипов (2014, с. 20). 
К зрелым годам нарастает самоирония и рефлексия над смыслом жизни, появляются нотки грусти и меланхолии. В качестве примера - стихотворение «Вечер»:

Дело движется к закату.

Угасает день.

День мечты свои куда-то.

Да, куда-то день.

Ничего уже не будет,

Как ты ни трудись.

В груде туч, в угрюмой груде

Тонет солнца диск.

Тьма глядит из каждой ямы,

Ниши и угла.

В темноте дома и храмы,

И на сердце мгла.

И уж не о милых встречах

Сердца боль и страсть,

А о том, как в этот вечер

Духом не упасть ${ }^{144}$.

Достойно внимания здесь и мастерское использование омоформ (день день), и аллитерация (угрюмая груда), но общий настрой оптимистическим никак не назовешь...

Что же касается общей техники стиха, то в сборнике «Про женщин» используются классические размеры - ямб, хорей, амфибрахий, нередко с перебивами ритма. Встречаются примеры дольника и верлибра. Приведем один пример:

Верлибр о любви и смерти

Я любил тебя,

И ты говорила, что любишь,

И хотя уйти ко мне не решалась,

Но была надежда,

И стоило жить.

Потом надежда исчезла,

Но ты обо мне горевала.

Не стало смысла жить,

Но был смысл умереть.

Потом горевать перестала -

Просто взяла и решила:

«Я всё пережила».

144 Осипов (2014, с. 43). 
Не стало смысла не только жить,

Но даже и умирать ${ }^{145}$.

В целом стихотворная техника Б.И. Осипова, можно сказать, довольно бесхитростна, хотя встречаются случаи и анжамбемана, и лексических повторов, и паронимической аттракции, например:

Опять оплакивает осень

Еще одно не наше лето,

И листья бьются, бьются оземь,

И сором делает их это.

Сор, сором, срам покроет долы,

Подходы к храмам и вокзалам

И будет там метаться голым,

Пока не снидет снега саван

(Без названия $)^{146}$.

Главное же - в книге нет никакого даже намека на языковедческие темы (сборник-то посвящен женщинам!), отсутствуют и лингвистические наблюдения, и соответствующие термины. Встречается несколько стиховедческих понятий (катрен, анапест, дактиль, верлибр), но этим связь с профессиональной ориентацией Бориса Ивановича исчерпывается. Отметим также, что для сборника «Про женщин» характерны вкрапления в текст чужих поэтических строк (об этом предупреждают курсив и сноски) - из произведений Пушкина, Лермонтова, Есенина... Это - отражение общего культурного багажа автора.

Владимир Александрович Карпов - белорусский языковед, применявший к материалу русского языка общую теорию систем Ю.А. Урманцева. Его основные лингвистические работы (монография «Язык как система»147, учебники, словари) лежат в русле компьютерной и системологической лингвистики.

Два поэтических сборника В.А. Карпова - «Амальгама» (2000) и «Дао» (2008) - довольно полно представляют совокупность эстетических образов и философских интенций ученого. В данном случае мы проанализируем первый из них.

Первое, что бросается здесь в глаза, - обилие посвящений. Стихи посвящаются родным, друзьям, учителям и кумирам (среди которых - А. Тарковский, Ю. Лотман, М. Терехова...). В этом проявляется яркое личностное начало: с помощью имен В.А. Карпов очерчивает границы своего хронотопа, своего восприятия мира. Кроме типично лирической пробле-

\footnotetext{
145 Осипов $(2014$, с. 50$)$.

146 Осипов (2014, с. 53).

147 Карпов (1992).
} 
матики (весна, детство, любовь, в меньшей мере - природа), здесь присутствуют отголоски войны, взгляд на русскую историю (декабристы, освоение Севера и т.п.) и на искусство, попытки философского осмысления жизни. Пример последнего (не имеющий специального названия):

Случайной бабочки визит, такой, как и она, случайный. Два лепестка от розы чайной сошлись в немыслимой связи.

Как обнаружишь, обнажишь таинственные эти скрепы двух невесомостей с секретом, где ошибалась даже Жизнь!

А ты - свободна и легка и на лету, и на помине, в пыльце сирени ли, жасмина вся пышешь страстью - увлекать.

Алхимик, в этом мире мер как жили бы и клён, и вишня, когда б не твой полет всевышний, не этот ветреный пример! ${ }^{148}$

Среди имен встречаются мифологические онимы (Сизиф, Икар и Дедал, Содом и Гоморра и др.), литературные герои (Фауст и Маргарита, Ромео и Джульетта, Гамлет, Гарпагон, Вий, Олеся и др.). Образовательный кругозор автора обнаруживает себя в именах Эвклида, Скрябина и Стравинского, Державина и Пушкина... Где-то встретится упоминание вершин русской классики («Горе от ума» или «Мертвых душ»), где-то мелькнет строка из Блока... Из топонимов большинство российские - Россия, Москва, Ленинград, Вологда, Михайловское, Смоленск, Тула, Сибирь и др., но встречаются также София, Париж, Хиросима... В целом это вполне классический набор ономастических ассоциаций.

Структура стиха Владимира Карпова в основном традиционна (это стандартные метрические размеры, нередко с перебивами). Встречается отход от силлаботоники к тоническому стиху. Активно используются созвучия (мой март - Монмартр (с. 8); Мороз. Не передать по Морзе (с. 27); Корпим. Кропим (с. 92) и т.п.). Рифмовка abab нередко в рамках одного стихотворения чередуется с abba, например:

Прекрасное не тяготеет к пользе, и часто, оставаясь не у дел,

148 Карпов (2000, с. 120). 
без клятв, без плача, без красивой позы не просто терпит - любит свой удел.

Что стоит жизнь с единственною гирей полезности? - Истертый эталон! Когда и за окном, и над столом бушует не гроза - полет валькирий!

(Без названия) ${ }^{149}$.

В некоторых стихах Владимира Александровича очевидно влияние Б. Пастернака и М. Цветаевой:

Я Вас у случайных прохожих вымаливал.

Вы знали? - Откуда! Я был Гарпагон, не брезговал даже секундами - мало ли? секунду мою отобрать?! Я вдогон

бросался за мигом! Сейчас вы узнаете, что Вашим следам удавалось не стыть!

Как? - Важно ли это!

Я жил, словно маятник, но к каждой минуте поставил посты...

(«Мы - знать бы!...») $)^{150}$.

Метафора у Карпова - важное средство создания поэтического образа: $\kappa$ весне расплаканные дороги (с. 29); заплатив червонцем октября (с. 87); транзистор давится Стравинским (с. 9о); а изумруд газонов так обманчив (с. 106) и т.п.

Для нас существенно, что в ряде стихотворений В.А. Карпов с помощью поэтических образов высказывает свое отношение к языку - и здесь сливаются воедино ученый и поэт:

И что мне имя, если без имен

Нас каждого и всех природа лепит? -

Что ей откроет наш несвязный лепет?

Ее язык утратил связь времен...

(«За болевым порогом бытия...») $)^{151}$.

Другое стихотворение (без названия), в котором фразы приобретают почти афористическую силу:

У слова свой удел, своя звезда.

Отдал его - в нем сразу начинают

соперничать и утренняя даль,

и горний свет, и глубина ночная.

149 Карпов (200о, с. 142).

150 Карпов (2000, с. 159).

151 Карпов (2000, с. 104). 
Я трачу их. Нет смысла приберечь на черный день: их не бывает, черных, когда и в даль, и в свет восходит речь, и в глубине стоит неизреченность ${ }^{152}$.

Находят свое отражение и темы разноязычия, перевода с языка на язык, происхождения слов:

Любовь и боль... Видна ль, слышна в них жизни нота? Весь мир без них - зевота, они без сна, без дна.

А - «ураган», «орган»!?

Как звук роднит значенья!

Как «пекло» и «печенье», как речка - берега!

(«Балкон распахнут в мир...») $)^{153}$.

В целом поэтическое творчество В.А. Карпова, которое еще ждет своего исследователя, включает в себя и образцы чистой лирики, и не менее яркие примеры интеллектуальной поэзии. Однако филологическая составляющая в этом наследии, прямо скажем, невелика. Кроме упомянутых «общегуманистических» мотивов («предмет и его имя», «сила слова», «смысл и звук»), автор не касается никаких лингвистических проблем. Рациональный объект научных исследований и чувственный объект поэзии для него разведены, разъединены.

Валерий Михайлович Мокиенко - известный российский ученый, глава Петербургской фразеологической школы, автор многочисленных лексикографических изданий - фразеологических и паремиологических словарей, собраний жаргона, словарей языка писателей, а также множества иных публикаций ${ }^{154}$. В 1997 году он издал сборник стихов «Ростки безвременья» ${ }^{155}$.

На книге лежит отблеск времени (показательно само ее название!). Среди ее ключевых понятий - время застоя, перестройка, гласность. Но озабоченность социальными процессами не умаляет, а, наоборот, усугубляет любовь автора к Родине:

Люблю Россию издавна,

С рожденьями и с тризнами,

С тоской и укоризною,

И с неба голубизною.

152 Карпов (2000, с. 121).

153 Карпов (2000, с. 163).

154 Герд (2010).

155 Мокиенко (1997). 
Люблю Россию тихую,

Люблю Россию дикую,

Такую превеликую,

Такую многоликую.

Люблю Россию-матушку,

Лежащую впокатушку,

И злобную, как мачеху,

И скорбную, как на духу.

Люблю Россию строгую,

Богатую, убогую,

Счастливую, несчастную,

Безмолвную и гласную.

Со всеми перестройками,

Со всеми неустойками,

$\mathrm{C}$ ее самообманами

И с глупыми Иванами.

Пускай - противоречия:

Любить, быть может, нечего, -

Любовь моя - то боль моя,

То волюшка невольная

(Без названия $)^{156}$.

С образа надвигающейся катастрофы начинается стихотворение «Судно в тумане»:

Судно наше стиснуто туманом,

И тисков тумана - не разжать.

Тонет судно вместе с капитаном,

И матросам - некуда бежать.

Впрочем - есть куда: сигналы SOS’a

Путь открыли им в широкий свет.

Но - молчат угрюмые матросы,

Недвижимы словно монумент...

Но концовка стихотворения, хоть и не вселяет надежды, все же обнаруживает в сложившейся ситуации положительные черты:

Знаю: нет поступка безрассудней,

Чем идти с чужой командой вниз...

Но останусь все-таки на судне:

Хоть мгновенье поживу... без крыс ${ }^{157}$.

156 Мокиенко (1997, с. 134).

157 Мокиенко (1997, с. 17). 
Проблематика стихотворений Валерия Михайловича очень широка: кроме «публицистической» темы, это чистая лирика (любовь, встречи, разлука, ревность...), работа («дело»), туристические походы с друзьями (порождавшие и тексты песен), моления...

Отношение к женщине представлено широким диапазоном чувств от «Исповеди Дон Жуана» до самоуничижения и растворения в любви:

То, что спутаны ель и сосна -

Вовсе не повод к панике:

Просто ныне такая весна,

Что можно не верить ботанике.

Лишь согласитесь вы погулять

В том же лесу со мною -

Я и рябину готов назвать

Елью или сосною

(Без названия) $)^{158}$.

При этом автор способен сохранять и присущую ему иронию:

Когда меня девы любили

За молодость, силу и стать,

Натуру мою они чтили,

А книг - не хотели читать.

Теперь же (как годы меняют

И чтенья, и жизни статут),

Мои они книги читают,

А силы и стати - не чтут

(Без названия) $)^{159}$.

Топонимика Мокиенко бескрайно широка (что отражает и его научную биографию): Петербург, Нева, Валаам, Москва, Кремль, Урал, Аральское море, Крым, Камчатка, Прага, Верона, Нью-Йорк, Америка, Германия, Новая земля и далее - вплоть до Мекки, Аида, Эдема и Галактики...

Среди литературных предшественников, отраженных в текстах, Пушкин, Булгаков, Шукшин, Бродский, Высоцкий, есть цитаты из Грибоедова, отсылки к Курту Воннегуту; один текст - романс «Станционный смотритель» - явная аллюзия к Пушкину...

Исторические, мифологические и литературные персонажи представлены тоже богато: Велес, Феб, Даждьбог, Кащей, Ганимед, Лазарь, Пенелопа, Крез, Отелло, Бонивур, дон Жуан, Чацкий, Маленький принц, Ванька Жуков и др.

Встречающиеся в стихах фразеологизмы (Гордиев узел, вернуться $\kappa$ свочм баранам, до лампочки и т.п.) прямо связаны с объектом научных

158 Мокиенко (1997, с. 74).

159 Мокиенко (1997, с. 52). 
исследований Валерия Михайловича ${ }^{160}$. Есть у него автобиографическое стихотворение «Терпи, казак...» - о том, как терпение, выдержка, целеустремленность постепенно выводят в «атаманы». И сегодня Мокиенко действительно, «атаман» от фразеологии. Но употребление устойчивых словосочетаний не составляет его прерогативы: фразеологизмы можно встретить в творчестве любого поэта.

А вот обращение ученого к лингвистическим проблемам представляет для нас значительно больший интерес. В частности, это тема «Предмет и его имя»:

\section{Названия}

Если знаешь названья цветов, Если помнишь названья деревьев До последних, до смертных часов Образ их от тебя неотъемлем.

Если знаешь людей имена, И фамилии помнишь, и клички, Значит - с ними во все времена Можешь снова вступить в перекличку.

Жизнь и Смерть, Перемирье и Бой, Ложь и Истина, Дело и Слово Всё, что названо Словом, - с тобой До последнего мига земного ${ }^{161}$.

И благодаря Слову, ради Слова ученый, собственно, и становится поэтом:

Мы на пули готовы идти за слова,

А когда не хватает нам слов,

Мы способны сердца, как словарь, разорвать,

Чтоб сочились слова для стихов

$$
(\text { «лова») })^{162} \text {. }
$$

Много в сборнике примеров паронимической аттракции, игры слов: ринг и рынок (с. 6), на паденье падок (с. 6), капЕльные капельки (с. 68), грешники безгрешные (с. 69), Кашмир - кошмар (с. 160), круча - кручина (с. 162) и т.п. Словообразовательные окказионализмы Мокиенко трудно признать удачными (белопарусье, шепотворенье, шееношенье, разменье, скелететь (глагол), плюшивенькая головка и т.п.). Но право на них имеет каждый поэт. В остальном его стихотворная техника вполне соответствует сложившемуся в русской литературе канону.

16о Степанова (2020).

161 Мокиенко (1997, с. 207).

162 Мокиенко (1997, с. 213). 
В целом поэтическое творчество В.М. Мокиенко вполне типично и ожидаемо для профессионала-филолога. И все же, заметим, в общей массе стихотворений собственно лингвистическая тематика занимает весьма малое место.

Людмила Владимировна Зубова - петербургский профессор, специалист по истории русского языка, автор нескольких книг по языку русской поэзии ${ }^{163}$. Но в данном случае речь пойдет о ее поэтическом сборнике «Платье» ${ }^{164}$. Стихотворения здесь пронизаны типично женской тематикой (можно сказать, в ахматовско-цветаевском духе): это влюбленность, любовь, разлука, одиночество, а также след, оставляемый в жизни... Поэзия же выступает как своего рода крест, расплата за душевные терзания автора:

Научишься себя вести,

Не предаваясь долгой грусти, -

Тебя поэзия простит,

Тебя поэзия отпустит

(«Зачем тебе писать стихи...») $)^{165}$.

Послания к близким людям, воспоминания о счастливых моментах, наблюдения за состоянием природы сочетаются у Зубовой с проникновенными психологическими зарисовками. Приведем два примера.

Лихой молодец и почти как отец,

Когда же придет этой пытке конец?

Обоим всё ясно. Зачем ты ко мне

Опять, как разбойник, приходишь во сне,

Когда я бессильна, когда ты любим.

Мы оба достоинство наше храним,

Как нищий - суму: подойдут - подадут.

Когда подадут, а когда - украдут

(Без названия $)^{166}$.

Бабье лето

Было не жалко мая, июня, июля,

Август уже проходит, ветры уже подули.

Стало в лесу сыро, в городе потемнело -

Вот и опять лето я прожить не сумела.

Февраля, марта, апреля

Бояться еще рано.

163 Зубова (200о); Зубова (2010) и др.

164 Зубова (2012).

165 Зубова (2012, с. 12).

166 Зубова (2012, с. 6о). 
И птицы не улетели

В свои жаркие страны.

Зонтик из рук рвется.

Но ведь еще не осень.

Августом обернется

Октябрь. Босоножки носим ${ }^{167}$.

Тонкое наблюдение - люди обычно по инерции еще какое-то время носят одежду и обувь, не соответствующую наступившему сезону, - оборачивается серьезной мыслью: о присущей женщине надежде на новые встречи, удачи и новую жизнь. Одежда оборачивается надеждой!

Филологические темы у Л. Зубовой не встречаются, специальная лингвистическая терминология отсутствует. Может быть, только в одном случае можно усмотреть профессиональную ориентацию автора:

То в песенке, то в образной системе

К запретной я переходила теме.

Но адресат мой - что за наказанье -

По-своему все те иносказанья

Читал, ничуть не искажая текста,

Так, что мне там не оставалось места.

Я с новым смыслом молча соглашалась,

И нам тогда просторнее дышалось ${ }^{168}$.

В этом стихотворении, кроме собственно любовной линии, можно увидеть чрезвычайно актуальную для современной филологии проблему: важность взаимопонимания и эмпатии (подстраивания под адресата), эффективность речевого акта, опасность коммуникативных неудач и т.п.

Не чуждо ученой чувство иронии, в сочетании с многозначностью и игрой слов:

Стихи про Вас, да не для Вас.

Да-да, когда

В последний раз

Ваш взгляд обжег да и погас.

Взлетел и скинул Вас Пегас.

Стихи про Вас, да не для Вас ${ }^{169}$.

Ономастикон Зубовой весьма беден, встречаются только единичные имена собственные. Можно сказать, что это - лирика, не имеющая ни своей пространственной, ни временной привязки: ее хронотоп - это чувственный мир ее автора. Характерно, что среди глагольных и местоименных форм высока доля 1-го и 2-го лиц - это типичный признак лирической поэзии.

167 Зубова (2012, с. 88).

168 Зубова (2012, с. 98).

169 Зубова (2012, с. 65). 
Что касается техники стиха, то у Л. Зубовой она тоже вполне традиционна в части ритмики, рифмы, расстановки знаков препинания и т.д. Силлабо-тоническое стихосложение чередуется в ее сборнике с тоническим (при котором в строках учитывается количество только ударных слогов). Приведем также пример такой поэтической вольности, как акцентный стих (с перебивом размера и опорой на количество слов в строке):

Светлая моя радость,

Тихое мое счастье -

Ясное, будто святость,

Дружеское участье -

Все это простым страхом

Сдавленное, да злым словом

Названное, пойдет прахом,

Рухнувшим пришибет кровом ${ }^{170}$.

Иногда встречается белый стих (не рифмованный) - с. 55, 59, 99, 139. Часто используется глагольная рифма и синтаксический параллелизм соседних строк, попадаются случаи анжамбемана и др. Словообразовательных новаций и игры со словами не встречается. Излюбленный прием усечение последней строки, например:

Что ж я любовную муру

Пробормотать не смела?

«Соври, что любишь». Не совру.

Я онемела ${ }^{17}$.

Наблюдения над поэтическим творчеством Л.В. Зубовой в общем подтверждают складывающееся у нас мнение: творческая личность стремится «развести» объекты своих научных исследований и эмоционального восприятия и переживания. В поэзии Людмила Владимировна несомненно женщина, в то время как в научной прозе ее «гендер» скрыт, не выпячивается.

Людмила Олеговна Чернейко - московский профессор, известная своими исследованиями в области лексической семантики, терминологии, анализа научной речи и художественного текста, автор монографии «Лингво-философский анализ абстрактного имени» ${ }^{12}$. В 2014 году издала под псевдонимом А. Воллис первый сборник стихов «Исцеление строкой», в 2018 - второй: «Созерцание». Именно эта книга будет подлежать анализу. В издательской аннотации к ней говорится: «Это стихи философа и филолога - отсюда редчайшее в наше время отношение к СЛОВУ,

170 Зубова (2012, с. 113).

171 Зубова (2012, с. 137).

172 Чернейко (1997). 
к его тончайшим смысловым оттенкам» ${ }^{173}$. Вообще-то отношение к слову, на наш взгляд, со временем становится все более заинтересованным и востребованным, и на смену эзотерическим и схоластическим умствованиям приходят серьезные лексикографические и метаязыковые исследования.

Тематика стихотворений Л.О. Чернейко широка: здесь автобиографические вехи, реверансы родным местам, природные зарисовки, впечатления от поездок (Польша, Южная Франция, Греция...), размышления над Свободой, Истиной, Судьбой, Временем (недаром докторская диссертация Людмилы Олеговны была посвящена абстрактной лексике).

Приведем в качестве иллюстрации стихотворение «Цикличность памяти» из «Зимнего триптиха». В нем автор в образной форме рассказывает об отношении человека к природе, к разным временам года - определяя при этом конечную цель как обретение «гармонии покоя»:

Я в зимние слова вой вьюги оберну,

узор снежинок прихотливый спрячу.

А летом красоту ушедшую верну,

уравновесив жар прожжённой солнцем дачи.

И летние слова свяжу в цветной букет -

в нём разнотравья дух до осени продлится.

А зимнею порой, скупой на белый свет,

мне память щедрая подарит вереницу

картинок лета - ливня и грозы,

травы и радуги над лугом и рекою.

Закрою ими я пробелы и пазы,

чтобы в зиме найти гармонию покоя ${ }^{174}$.

Филологическая составляющая в анализируемом сборнике стихов Л.О. Чернейко находит себе отчетливое выражение. И гуманитарное образование автора, и ее профессиональный интерес к «тайнам слова» выливаются, в частности, в такие открытия, касающиеся творческого процесса:

Мысль бьётся о смыслы, стучится в значенья, мозаика букв не слагается в текст.

Но он уже есть, его предназначенье прорваться наружу теперь или «next».

И позже, когда через главное слово, как будто случайно, совсем невзначай, из мысли подспудья вдруг тянется снова такой мне ненужный сорняк-молочай,

173 Воллис (2018).

174 Воллис (2018, с. 121). 


\begin{abstract}
я, текст охраняя от слов неугодных от низших чинов и невзрачных сортов, рвану дерзко корень, оставив свободной одну вертикаль для сюжетных основ.
\end{abstract}

Но сила потока природной стихии, асфальт прорывая, взорвётся ростком, таким очевидным, что вставлю в стихи я слова-молочаи в порыве простом.

$$
(« \text { Неслучайность») })^{175} \text {. }
$$

Та же мысль - о давлении языковой стихии на поэта - встречается в творчестве Чернейко еще не раз. Так, даже гимн Слову, перед которым автор, по ее выражению, «трепещет», оборачивается в конце концов, похвалой форме:

Я, нищий духом, не взыщу мне есть с кого писать основу, неколебимую, как Слово, перед которым трепещу.

Пред ним склоняюсь, не ропщу. В который раз я вижу снова мне смысл открывшийся в нём новый. Я ничего не пропущу.

Но иногда на стыке форм так смысловой простор дурманит, как будто пролит хлороформ.

И трансцендентом бездна манит... Мне нет преграды в виде норм. Я знаю - форма не обманет

$$
(« Ф о р м а »)^{176} \text {. }
$$

Естественно, в этих стихах нередко используется лингвистическая терминология: слова вроде синтаксис, корень (слова), знаки препинания и т.п. - здесь на своем месте. В стихотворениях же, посвященных Учителям - К.В. Горшковой, М.В. Панову, Н.И. Толстому, - речь прямо идет о языковедческих понятиях.

Впрочем, в стихах Людмилы Олеговны много и других специальных терминов - таких как квазар, пульсар, мифологема, антидот, континуум, деструктивность, экзистенция, резистентность, стигматы, усталость металла, тектонический сдвиг, Большой Взрыв, инфернальный, плазмомагменный и т.п. Как сугубо философские размышления, так и лирические эпистолы не обходятся без вкрапления излюбленных абстрактных терминов:

175 Воллис (2018, с. 22).

176 Воллис (2018, с. 184). 
Плывут столетья. Скрыт от нас их лик.

Мы только знаем по простым приметам, что, сколько бы ни длился мига миг, останутся присущими предметам

константы формы - тверди бытия, его дискретность и вариативность определившие. Так чашу для питья нам гончара подарит креативность («Цвет и формы») $)^{177}$.

Зачем я вам в таком простом обличье, где всё понятно сразу и без слов, с душою, обожжённою приличьем неискренностью жизненных основ? $(« \text { Стансы») })^{178}$.

Представлен в стихах (некоторые из них, кстати, написаны от мужского лица) широкий диапазон имен собственных, главным образом из области мифологии (Сизиф, Титан, Голиаф...) и изобразительного искусства (Босх, Мунк, Гауди...). В стихотворении «Китч гламура» речь идет о Ван Гоге, творчество которого массовая культура сводит к тиражированию немногих образов. «Миром китч сурово управляет...». Эта максима находит себе подтверждение во многих текстах сборника.

Используются созвучия: покорность непокоренная (с. 75), в деревне древней деревья дремлют (с. 70), пыль - быть - боль (с. 161), разлюбленный возлюбленный (с. 128; в последнем случае интересно столкновение причастия с субстантиватом). Излюбленный прием - анжамбеман, вплоть до очень сильного: помещения предлога в конце строки (с. 67, 103) или разрыва слова между строками (с. 13). Встречаются неологизмы: сnозаранить, пропунктирить, щедроволный, узорочье (существительное), вегеточревоточина и др.

Филологический опыт Л.О. Чернейко заставляет ее экспериментировать и с брахиколоном - стихотворением, состоящим из односложных слов. Казалось бы, после попыток начала XX века (односложных сонетов В. Ходасевича и др.) это уже пройденный для русской поэзии этап, но тут мы к нему возвращаемся:

Вниз - спуск.

Вверх - свет.

Парк пуст.

Лета нет.

Свет чист.

Спуск крут.

177 Воллис (2018, с. 185).

178 Волдлис (2018, с. 174). 
Жёлтый лист.

В ряске пруд.

Сник лес.

Ветра свист.

Вихрь-бес

Кружит лист...

(«Перспективы осени») $)^{179}$.

Такие экзерсисы отдают сконструированностью и сегодня напоминают пародийные строки Татьяны Толстой: O, Кипр клёв! Пляж, бар - сплошь плюш; сок, джин, дринк. Как ночь - муж в душ, дочь - прочь, тут грек Макс - тук-тук! - враз секс, кекс, бак, крекс, фекс, пекс. Вот так-с!'80. Любопытно, что М.Л. Гаспаров и Т.В. Скулачева специально проанализировали использование односложных слов в русской поэзии и показали на материале Ломоносова, Жуковского, Лермонтова и Брюсова, что самые частые из односложных лексем образуют «набор, вполне достаточный для построения картины мира: бог, мир, рок... век, день, час... край, путь, храм... свет, грудь, взор... жизнь, смерть, сон.... ${ }^{181}$. В данном случае, в стихах ЧернейкоВоллис, очевидно, о таких высоких целях речь не идет. Но попытка осмыслить мир как «движенья бесцельного вечный трагизм» ${ }^{182}$ не мешает автору проявить свои филологические интенции, поиграть со словами.

Проанализированные нами тексты воссоздают различные образноэмоциональные картины мира семи ученых-филологов. Конечно, не только литературовед-профессионал, но и рядовой читатель может почувствовать разный уровень этих произведений. Но ведь стихи, о которых идет речь, писались не для широкой аудитории, не в расчете на популярность, на широкую известность, а более всего - для «своего круга». Ученому хотелось показать иные, скрытые до тех пор грани своего «я»и просто поговорить «о другом».

Что касается внешней стороны стиха, то, за исключением М.В. Панова, во всех обследованных случаях представлены в основном классические формы и размеры; то же можно сказать об использовании рифмы. Специальные приемы (аллитерация, анаграмма, анжамбеман, хиазм, синтаксический параллелизм, кольцевая структура и т.п.) используются сравнительно редко и не привлекают к себе внимания. Как правило, соблюдается расстановка знаков препинания; очень часто, в соответствии с традицией, каждая строка начинается прописной буквой. Можно сказать, что лингвисты довольно «дисциплинированны» в плане языковой техники.

179 Воллис (2018, с. 188).

180 Толстая (2006, с. 223-224).

181 Гаспаров, Скулачева (2003, с. 47).

182 Воллис (2018, с. 15). 
Если поэт (поэт как таковой) в меру своих сил рефлексирует над инструментом своего творчества - языком и даже совершает в нем те или иные открытия ${ }^{183}$, то лингвист, для которого язык - сфера профессиональных занятий, должен был бы уделять этому инструменту удвоенное внимание. В данном случае мы и ставили своей целью реконструировать внутренний мир лингвиста-поэта, выяснить, как соприкасаются в сознании и творчестве гуманитария поэтическая (эмоционально-образная) и научная (профессиональная) составляющие. Как соотносятся эти два вида ментальной деятельности у одного и того же человека? Конкурируют ли они там, корреспондируют ли, «помогают» ли друг другу? Проще говоря, нас интересовало, какое место занимает язык и его единицы в системе поэтического наследия лингвиста.

Эта проблема имеет свою предысторию. Сегодняшнее общество приветствует профессиональную специализацию: индивид стремится достичь совершенства в своей области. Не то - в античную эпоху, когда наука находилась на стадии становления, а в качестве терминов использовалась бытовая лексика. «Исторически необходимая установка на преобразование слова ради нужд философского языка закономерно побуждала приглядываться к слову и на разные лады разрабатывать его возможности также и там, где это не требовалось никакой утилитарной надобностью, безмотивно - раз начавши, невозможно остановиться. Ум эллинского философа - почти непроизвольно работающий «генератор» тропов, антитез, всякого рода словесной и просто звуковой игры» ${ }^{184}$. Нынче язык науки и язык поэзии - это, по сути, антиподы на функционально-стилистическом пространстве языка.

Работы Т.В. Черниговской и ее соавторов, основанные на экспериментальном (хотя и ограниченном) материале, подтвердили давно известную идею функциональной специализации полушарий головного мозга. В самом общем виде эта идея сводится к следующему тезису: разные типы мышления, свойственные человеку, связаны с «распределением обязанностей» между правым и левым полушариями. Причем эта разная умственная деятельность соотносится с разными типами «текстов культуры». Разумеется, в ходе ментальной деятельности полушария взаимодействуют, но одно из них обычно принимает на себя доминирующую функцию: «Диалог полушарий - это диалог двух разных логик мышления, разных систем осознания (=организации) мира»185.

Правое полушарие, «хранящее готовые куски текста» типа коллокаций и идиом, ориентировано на обобщение эмпирического опыта, на со-

183 Норман (2012б).

184 Аверинцев (1979, с. 53).

185 Черниговская, Деглин (1984, с. 63). 
здание целостного образа, гештальта. Левое полушарие, специализирующееся на анализе, дешифровке и ориентирующееся на метаязыковые конструкты и связи, склонно к логическому теоретизированию. Эти два вида мозговой деятельности Т.В. Черниговская и В.Л. Деглин условно называют метафорическим и силлогистическим мышлением и прямо соотносят их соответственно с поэзией и наукой ${ }^{186}$.

Лингвист-поэт оказывается, таким образом, носителем двух «языков» - и двух типов мышления. И вот теперь мы можем уточнить интересующий нас вопрос. Если языкознание - это наука, пусть даже не совсем «точная», то при производстве и восприятии лингвистических текстов должна преобладать аналитическая работа левого полушария. Именно оно обеспечивает для ученого-филолога его профессиональную деятельность. Сохраняются ли эти навыки и традиции, когда лингвист облачается в тогу поэта? Ведь при производстве и восприятии поэтических текстов человек должен перейти к иному - «метафорическому», образному взгляду на мир... Как разрешается это противоречие, как происходит в сознании человека этот «диалог полушарий»?

Говорить в прямом смысле о переключении кодов (code switching), как это делается применительно к ситуации билингвизма, здесь, очевидно, не приходится: слишком велика общая языковая база у ученого и поэта. Но вполне правомерно говорить о смене парадигмы, об иной «точке зрения» на мир.

В большинстве случаев мы наблюдаем в обследованном материале, что пишущий стихи лингвист старается отвлечься от своих профессиональных интересов, «забыть» о них. Это значит - лингвистические проблемы редко становятся объектом поэзии, и соответствующий пласт лексики (а также часть грамматики) становятся невостребованными. Активизируются иные связи между словами - фонетико-графические, ассоциативные, в том числе опосредованные (цепочечные)... Иными словами, лингвисты-поэты ничем из поэтической среды не выделяются. Язык инструмент, а не объект их творчества. Тематика проанализированных стихотворений - различная, но, в общем, довольно типичная для лирики. Конечно, мы находим в этих стихах биографические, хронотопные и гендерные особенности ученых, но говорить о какой-то особой системе их образов невозможно.

В то же время научный опыт исследователя, его профессиональные «шоры» дают о себе знать. Лингвист-поэт слегка скован навыками деятельности своего левого полушария. Это значит, что степень идиоматичности его текстов сравнительно невелика, метафорика количественно и качественно ограничена, степень новаторской смелости уступает смело-

186 Черниговская, Деглин (1986, с. 68). 
сти поэтов - не лингвистов. Возможно, этот вывод будет подвергнут коррекции при привлечении стихотворных текстов других языковедов. Особый интерес представляет поэтическое творчество представителей точных наук, технических специальностей: у них «силлогистическое» и «метафорическое» мышление должно быть разведено еще сильней. В любом случае разные виды мозговой деятельности, соотносящиеся с разными типами «текстов культуры», нуждаются в дальнейшем исследовании. 


\section{Глава 3. «Отдаленное знакомство слов» (о семантических и фонетических связях между словами в стихотворении) ${ }^{187}$}

В языковой памяти человека хранится огромное количество готовых к употреблению единиц, в том числе десятки тысяч слов. Не подлежит сомнению, что это множество каким-то образом упорядочено, организовано. Виды связей между словами в сознании давно составляют один из объектов лингвистических исследований. Кроме собственно наблюдений над речевой практикой человека (в условиях разговорной речи, в художественных текстах, при измененных состояниях сознания и т.п.), могут в данных целях использоваться и отработанные экспериментальные методики. В частности, весьма важным подспорьем в изучении организации словарного состава является свободный ассоциативный эксперимент. Большое количество испытуемых (как правило, не менее 50о) отвечают на заданный словесный стимул первой приходящей в голову реакцией. А с учетом того, что и стимулов используется достаточное количество (за основу обычно принимается список из 100 слов Кент-Розанова $\left.{ }^{188}\right)$, в результате таких экспериментов мы получаем объективную и довольно полную картину словесных связей в сознании. Словари ассоциативных норм разных языков фиксируют эти связи и одновременно демонстрируют их сложный и многовекторный характер.

Скажем, на стимул ХЛЕБ носители русского языка чаще всего отвечают следующими реакциями (после ответов указано их количество, по данным Словаря ассоциативных норм русского языка $\left.{ }^{189}\right)$ :

ХЛЕБ - насущный 123, соль 119, черный 49, белый 38 , свежий 19, имя существительное 17, вкусно 16, съесть, черствый 15, булка 14, пшеница, ржаной, рожь 12, мягкий, поле 8, еда 7, пища, розы 6, жизнь, украинский 5, горячий, кушать, масло, печь, стол 4, булочная, горький, купить, магазин, молоко, нож, халва $3 \cdots$

(мы приводим здесь только начальную часть словарной статьи - слова с частотой 3 и выше).

187 В основе раздела - дополненная и отредактированная статья Б.Ю. Нормана, опубликованная со ссылкой на поддержку Немецкого научно-исследовательского сообщества (DFG), Проект FOR 2603 «Русскоязычная поэзия в транзите» (Трирский университет, Германия). Первая публикация: Норман Б.Ю. (2019): «Отдаленное знакомство слов» // Психолингвистические аспекты изучения речевой деятельности. Вып. 17. Труды Уральского психолингвистического общества. Екатеринбург. С. $155^{-178}$.

188 Норман (2011б, с. 67-69).

189 Леонтьев (ред.) (1977, с. 185). 
Практически все эти ответы укладываются в известные, многократно описанные классы психолингвистических реакций ${ }^{190}$. В самом общем виде ассоциаты подразделяются на реакции синтагматические и парадигматические, или реакции по смежности и по сходству ${ }^{191}$. Более сложные, когнитивистские, классификации строятся «на основе общения человека с подобными объектами» (имеются в виду участники фрейма) ${ }^{192}$. В приведенном случае реакции на стимул ХЛЕБ - черный, белый, свежий, черствый, ржаной, мягкий и др. - типичные синтагматические ассоциации («по смежности», образующие подчинительные словосочетания). Реакция ХЛЕБ - насущный - также синтагматическая, но подтверждаемая цитатой (словами православной молитвы). Реакции ХЛЕБ - булка, еда, пища - парадигматические (основанные на противопоставлении по одному, хотя бы и существенному, признаку). Реакции соль, вкусно, пшеница, рожь, поле и др. - тематические. Реакция имя существительное цитатная (отсылка к названию романа российского писателя Михаила Алексеева «Хлеб - имя существительное» и одноименного художественного фильма). Той же природы реакция розы (английский фильм 2000 г. «Хлеб и розы»)...

Важно подчеркнуть, что всё это, так или иначе, - смысловые реакции. Они воплощают в себе многообразные семантические связи слова ХЛЕБ с другими русскими словами. (Может быть, только в реакции ХЛЕБ халва, кроме «гастрономической» связи, можно усмотреть формальное основание в виде созвучия, консонантной переклички [x] - [л]/[л'] $[б] /[в]$.$) Нейрофизиологи и психолингвисты, изучавшие речевую дея-$ тельность экспериментальными методами, многократно указывали, что доминируют в этом процессе именно смысловые векторы. А.Р. Лурия в своих пионерских работах по нейролингвистике показывал, что «вокруг каждой лексической единицы действительно создается многомерная сеть связей, причем в норме преобладающую роль играют смысловые связи (семантическое поле), тормозящие звуковое сходство, а в патологических или тормозных состояниях заторможенные примитивные (звуковые) связи растормаживаются и уравниваются по своему значению со смысловыми связями» ${ }^{193}$.

И позже экспериментальные исследования подтверждали, что «реакции по созвучию, как правило, относились к категории второсортных: диффузных, примитивных, простых и т.п.»194. Иными словами, формальное (звуковое или буквенное) сходство очень редко служит основанием

190 Клименко (1974, с. 49-51).

191 Мартинович (1993, с. 96).

192 Миронова (2011, с. 113).

193 Лурия (1975, с. 36).

194 Ушакова (1979, с. 46). 
для объединения слов в сознании. Такие ассоциации также представлены в Словаре ассоциативных норм (например, ГОЛОВА - олово, ГОЛОС - колос, ДЕНЬ - деньги, ЖУРНАЛ - журавль, ПОВОД - поводырь, СЧЕТ - щетка, УГОЛ - угорь и др.), но доля их в общем объеме ответов крайне мала: как правило, это единичные реакции.

Разумеется, носитель языка способен воспринимать и семантизировать и такие единицы, которые ранее ему никогда в речи не встречались. В таком случае особый интерес представляют его реакции на псевдослова - искусственные, придуманные лексические единицы. А.Е. Кибрик, специально предлагавший испытуемым стимулы типа динист, пармочек, сматливо, бодина, установил, что в большинстве случаев они воспринимались «не как ни с чем не ассоциируемые звуковые отрезки, а как незнакомые слова, которые в принципе могут встретиться в русском тексте или словаре»195. Это означает, с одной стороны, что испытуемый относился к экспериментатору с достаточной долей уважения (не ожидая подвоха), а, с другой стороны, довольно скептически оценивал свой собственный уровень владения языком - он принимал, что многие слова родного языка ему могут быть незнакомы. А в диссертации В. И. Малова было показано, что «самые простые и в норме второстепенные звуковые связи становятся доминирующими в ситуации интерпретирования асемантичного текста» 196 . При этом надо помнить, что такого рода элементы (глокая куздра, хливкие шорьки и т.п.) не только используются в научных экспериментальных целях, но и составляют естественную часть текстов литературного авангарда. Нас же в этом интересуют те внутренние механизмы, которые позволяют носителю языка в какой-то степени «освоить» искусственную лексему. К примеру, выяснилось, что если задать в качестве стимула псевдослово СТРОН, то процент фонетических реакций сильно возрастает: у испытуемого просто нет семантической точки отсчета, смысловой базы, на которую он бы мог опереться. И основная масса ответов в таком случае - это слова вроде трон, стройка, страна, патрон, стон, звон и т.п. 197 .

Если вернуться к стандартным (частотным и типичным) смысловым реакциям, то следует уточнить: они составляют обычно более $80 \%$ всех ответов. Однако остается некоторое количество реакций, встретившихся на слово-стимул всего 1-2 раза и требующих специального комментария. С точки зрения лингвиста, эти случаи представляют особый интерес, потому что они объясняются не только особенностями личности испытуемого, но и спецификой механизма ассоциирования.

195 Кибрик 1968, с. 159).

196 Малов (2001, с. 16).

197 Пузырев (2014, с. 161-166). 
В частности, на стимул ХЛЕБ в том же Словаре ассоциативных норм, в конце списка реакций, приводятся следующие ассоциации с частотой 1: возраст, Вьетнам, город, кот, нога, полушка, разведчик, роза, яблоко раздора...198.

Некоторая странность таких реакций, т. е. наблюдаемый в этих случаях «когнитивный диссонанс», наводит на мысль, что между словомстимулом и словом-реакцией должен существовать какой-то «мостик», промежуточное звено. Мысль о возможности опосредованных, «цепочечных» ассоциаций в сознании человека была высказана очень давно. Еще в 4о-е годы прошлого века американские психологи Ч. Кофер и Д. Фоли экспериментально показали, что каждое слово в сознании человека связывается с другими словами многочисленными и многообразными связями. Эти связи могут быть смысловыми и формальными, прямыми и опосредованными; в последнем случае они образуют цепочки, ветвящуюся сеть вербальных ассоциаций, доходящую до 8 ступеней 199.

Рассмотрим несколько простых случаев.

В Словаре ассоциативных норм на стимул БУМАГА зафиксирована реакция мел. Вряд ли это рефлексия устойчивого выражения мелованная бумага. Скорее перед нами результат мысленного переноса по цвету: БУМАГА - (белая) - мел. Восстановление промежуточного звена белая делает реакцию мел абсолютно естественной.

Точно так же пара УГОЛ - резкий нуждается для своей мотивировки в подстановке «посредника» острый (острый угол - термин геометрии, а синонимические связи, в широком смысле этого слова, относятся к числу наиболее естественных при ассоциировании $\left.{ }^{200}\right)$.

На тот же стимул УГОЛ встретился и ответ поэт П. Коган, опирающийся в своей основе на прецедентную (цитатную) ассоциацию - строки из стихотворения Павла Когана: Я с детства не любил овал, Я с детства угол рисовал...

Среди реакций на стимул БЕЛЫЙ есть ответ квадрат; скорее всего, это результат последовательной ассоциации БЕЛЫЙ - (черный) - квадpam. «Черный квадрат» - известное полотно супрематиста Казимира Малевича. У художника есть также картина «Белый квадрат», но это название по своей популярности не идет ни в какое сравнение с «Черным квадратом». Национальный корпус русского языка дает такие цифры: белый квадрат - 17 документов, 17 вхождений, черный квадрат - 68 документов, 132 вхождения ${ }^{201}$.

198 Леонтьев (ред.) (1977, с. 185-186).

199 Cofer, Foley (1942, p. 528-530).

200 Дударева (2012, с. 11).

201 НКРЯ (15/08/2019). 
А реакция хлев на слово-стимул ЧИСТЫЙ так же, очевидно, опосредована антонимическим звеном грязный: ЧИСТЫЙ - (грязный) - хлев. Хлев, по-видимому, в представлении городского жителя служит одним из прототипов физической нечистоты.

Подобные примеры заставляют психолингвистов говорить об опосредованных реакциях как о типичных и естественных ${ }^{202}$. Но заметим: во всех приведенных случаях мы имели дело с последовательностью из двух ассоциаций. Они могут выступать в разных сочетаниях: первая ассоциация - синтагматическая, вторая - парадигматическая, или наоборот. Однако обе эти связи, участвующие в цепочке, - смысловые. Для дальнейшего же изложения и объяснения некоторых редких, уникальных психических реакций стоит затронуть вопрос об общих механизмах ассоциирования и о соотношении двух возможных его оснований - семантического и формального.

Возьмем, к примеру, реакцию ХЛЕБ - полушка. Полушка вообще-то старинная мелкая медная монета в $1 / 4$ копейки (и соответствующая цена). Современному носителю русского языка это слово знакомо более всего по пословице За морем телушка - полушка, да рубль - перевоз. Однако сегодня хлеб своей ценой вряд ли может напоминать полушку (среди реакций на ХЛЕБ в Словаре ассоциативных норм представлена и такая, относящаяся к годам, когда словарь составлялся: 14 копеек). Вместе с тем, испытуемые хорошо ощущают хлеб как товар: среди ответов встречаются купить, магазин, булочная... Следовательно, логично восстановить тут трехзвенную цепочку ассоциирования: ХЛЕБ - (цена) - полушка (с мысленным выходом на пословицу).

Однако для пары ХЛЕБ - полушка есть и другие варианты восстановления промежуточного звена. Это существительные половинка и горбушка. Оба слова легко сочетаются с исходным хлеб (половинка хлеба, горбушка хлеба). Но характерно, что для обеих предположительных цепочек:

$$
\begin{aligned}
& \text { ХЛЕБ - (половинка) - полушка и } \\
& \text { ХЛЕБ - (горбушка) - полушка }
\end{aligned}
$$

первый «шаг» ассоциирования делается на смысловой основе, а второй на формальной. Половинка - полушка и горбушка - полушка - это, скорее всего, фонетические ассоциации!

Сделанное наблюдение не только допускает разные варианты ассоциирования в сознании носителя языка, но и в каком-то смысле уравнивает между собой в правах семантические и фонетические основания этих связей. И это далеко не единственный случай. Возьмем еще один

202 Мартинович (1993, с. 96). 
пример из Словаря ассоциативных норм: ассоциацию СТОЛ - телеграф ${ }^{203}$. Наиболее естественный способ ее объяснения - это предположить возникновение в сознании носителя языка промежуточного звена (телеграфный) столб:

$$
\text { СТОЛ - (столб) - телеграф. }
$$

Здесь первый шаг ассоциирования - формальный, а второй - смысловой. Получается, что словесные ассоциации в сознании могут иметь вид сложных комплексов, последовательных или ветвящихся цепочек, и смысловое основание в них может чередоваться со звуковым ${ }^{204}$. Это заставляет нас вернуться к проблеме участия фонетических связей в процессе речепорождения - при выборе говорящим конкретной лексической единицы. По-видимому, представленные в обычной ситуации в виде скрытых, фоновых знаний, в определенных дискурсивных условиях они могут активизироваться. В уже цитированной книге Т. Н. Ушаковой говорится: «Небезынтересно поставить вопрос, какую роль в психической жизни человека играют связи по созвучию. Вероятно, они имеют значение в рифмовании, стихосложении. Следует полагать, что поэтически одаренные люди имеют особенности нервной деятельности, обусловливающие легкое установление и воспроизведение связей между созвучными словами» 205 .

Среди особых дискурсивных условий, в которых формальные (буквенно-звуковые) связи могут как раз превалировать, брать верх, следует специально отметить ситуацию поэтического творчества. О том, что здесь, в поэзии, звук становится равным смыслу или даже определяет смысл, многократно говорили и писали сами поэты. Обращали на это внимание и языковеды:

Факты ритмики и эвфонии, вообще говоря, представляют собой звуковую оболочку языка, отвлекаемую от ее языковой функции и превращающуюся в материю sui generis, лишенную всякого предметного содержания, но зато наделенную опосредованной экспрессивностью... Но они могут иметь также и свой смысл, участвовать в передаче поэтических значений ${ }^{206}$.

Разумеется, поэт имеет право на свое видение данной проблемы. Нередко связь смысла со звуком мотивируется им исторически, и тогда мы имеем дело со своего рода поэтической этимологией или псевдоэтимологией. Вот стихотворные подтверждения этой мысли:

203 Леонтьев (ред.) (1977, с. 169).

204 Норман (1994, с. 71-74); Норман (20116, с. 71-72).

205 Ушакова (1979, с. 46).

206 Винокур (1959, с. 252). 
Одиночество. Корень ночь.

Но извлечь одиночество с корнем

мне никто не сможет помочь...

(В. Павлова. «Одиночество. Корень ночь...») ${ }^{207}$.

Слова «резня» и «розни»

Всегда живут в приязни,

А в тихом слове «козни»

Живет зародыш «казни»...

(В. Орлов. «Близкие слова») $)^{208}$.

Здесь столько говорят о ностальгии...

А я все время слышу эту «сталь»...

(В. Долина. «Здесь столько говорят о ностальгии...») 209.

А более отчетливо эта идея выражена в следующих строках прозаика Андрея Битова (который, кстати, и сам пробовал свои силы в поэзии):

Я, право, не знаю, что было бы с русской поэзией и отчего бы она была именно русской, кабы не приговоренная бедность рифм «кровь - любовь» и «человек - век». И что было бы со смыслом русской литературы и отчего бы она была именно русской, кабы не были созвучны «деревня - деревья - древний» и «крест - крестьянин - христианин». Здесь лежат первые и скорее впоследствии забытые, чем уточненные, связи языка и жизни. Их-то, возможно, и помнит поэт в большей степени, чем простые смертные ${ }^{210}$.

Надо сказать, что стремление связать между собой слова по внешнему сходству соответствует и наивным интенциям обывателя. Ведь обычному носителю языка тоже «слышатся» в подушка - ушко, в довлеть - давить, в насмарку - насморк, в нувориш - вор, воришка, в помпадур - дура (а, может, еще и помпа), в спартакиада - спорт и т.д.; и то, что эти этимологии - ложные, никого не волнует.

Однако подчеркнем: обостренное внимание к звуковой стороне речи (или даже ее приоритет) свойственно все же поэзии, причем не исключительно стихотворному творчеству, а особому взгляду на мир, при котором мыслительная деятельность, направленная на создание образа, сопровождается постоянным подбором и «взвешиванием» единиц плана выражения. В сознании эти механизмы взаимодействуют, переплетаются друг с другом. Очень ярким примером может служить проза Марины Цветаевой - фактически это попытка передать на бумаге феномен, известный психолингвистам под названием внутренней речи. Два маленьких фрагмента из повести «Мать и музыка»:

207 Павлова (2004, с. 85).

208 Орлов (1990).

209 Долина (2018, с. 152).

210 Битов (1986, с.51). 
Как с первой до последней минуты давала, - даже давила! - не давая улечься, умяться (нам - успокоиться), заливала и забивала с верхом - впечатление на впечатление и воспоминание на воспоминание - как в уже не вмещающий сундук (кстати, оказавшийся бездонным), нечаянно или нарочно?211.

...Но у педали была еще одна - словесная родня: педель, педель студенческих сходок, педель, забравший на сходке нашего с Асей до собачьего вою любимого Аркадия Александровича (Аркаэксаныча)... И, конечно, такой же один, как педали - две. Но, назвав педеля, не могу не упомянуть его словесной родни: Пуделя, белого ученого Капи из «Sans Famille», который рвет педеля за панталоны - тогда педель Аркаэксаныча выпускает, - и их общей, педеля и педали, словесной родни, двоюродной сестры падали, той падали, которая пахнет - одну секунду - и каждый раз - и безумно сильно в бузине, у самого подступа к нашей тарусской даче...212.

Мы видим, что параллельно с развитием смысловой ткани текста тут происходит столь же активное следование формальным ассоциациям, уводящим автора в сторону от генеральной линии повествования: педаль - педель - пудель - панталоны - падаль... Вообще внимание к звуковой стороне языка, или так называемая анафония, повтор определенных звуков и созвучий, занимает в речевой деятельности любого человека большее место, чем это обычно представляется ${ }^{213}$. Что же касается художественных текстов, то тут насыщение определенными фонемами справедливо рассматривается как источник дополнительной иллокутивной силы, описываемой в терминах «магии слов». Элементы плана выражения (фонемы, буквы) приобретают собственное значение. При этом семантизация незнаковых единиц в художественном произведении происходит различными путями. Один из них, в соответствии с идеями фоносимволизма, - поиск глубинных корреспонденций между звуком и смыслом в человеческой психике. В более простом и естественном случае «звуковые повторы могут устанавливать дополнительные связи между словами, внося в семантическую организацию текста со-противопоставления, менее ясно выраженные или вообще отсутствующие на уровне естественного языка» ${ }^{214}$. В частном случае анафония преследует ту цель, чтобы в подсознании читателя воссоздались разбросанные, распределенные по тексту части ключевых слов; в такой ситуации правомерно говорить об анаграмме. Ср. также понимание парономасии и паронимической аттракции как стержневого приема «художнической рефлексии»

\footnotetext{
211 Цветаева (1984, 2, с. 90).

212 Цветаева (1984, 2, с. 101-102).

213 Григорьев (1977, с. 186-239); Пузырев (2014, с. 112-130) и др.

214 Лотман (1970, с. 136-137).

215 Григорьев (1979, с. 259-267).
} 
В качестве иллюстрации приведем строфу из стихотворения Владимира Набокова, посвященного Ивану Бунину:

Ты любишь змей, тяжелых злых узлов

Лиловый лоск на дне сухой ложбины.

Ты любишь нежный шелест голубиный

Вокруг лазурных, влажных куполов

(«Как воды гор, твой голос горд и чист...») $)^{216}$.

Инструментовка на шипящие [ж], [ш], свистящие [з], [с], плавные [л] и [л'] пронизывает эти строки, усиливая их внутреннюю организацию. Возникающий зрительный образ (в том числе цветовой: лиловый, лазурный) сопровождается звуковым: шипением змей и шелестом голубиных крыльев.

Но это - взгляд на звуковую структуру стиха со стороны реципиента, читателя. А для поэта в процессе творчества звуковые корреспонденции, формальные ассоциации с другими словами служат подсказками в выборе очередного слова, направляют течение его мысли. Звук ведет за собой смысл! Покажем это на двух примерах из поэзии Иосифа Бродского.

Один певец приготовляет рапорт,

другой - рождает приглушенный ропот,

а третий знает, что он сам - лишь рупор,

и он срывает все цветы родства

$$
\text { («Одной поэтессе») })^{217} \text {. }
$$

Почему различные роли и статусы поэта сравниваются то с докладом или доносом (panopm), то с негромким недовольством (ponom), то с усилителем звука (рупор)? По-видимому, именно такой (а не другой) подбор метафор обусловлен фонетическим сходством этих слов.

По утрам, когда в лицо вам никто не смотрит,

Я отправляюсь пешком к монументу, который отлит

Из тяжелого сна. И на нем начертано: Завоеватель...

Но читается как «завыватель». А в полдень - как «забыватель» («Элегия») $)^{218}$.

В данном случае еще более очевидно, что от уже выбранного слова высокой семантики завоеватель перекидывается фонетический мостик к сниженному разговорному завыватель (окказиональная номинация), а от того - к столь же необычному ироническому забыватель.

Мы видим, как межсловные связи, парадигматические и синтагматические, заложенные в языке, ведут поэта, руководят им в его творчестве. Свою лекцию при получении Нобелевской премии Бродский закончил словами:

216 Набоков (1920).

217 Бродский (1992, 1, с. 113-114).

218 Бродский (1992, 2, с. 159). 
«Человек, находящийся в подобной зависимости от языка, и называется поэтом» ${ }^{219}$. И в том же публичном выступлении он отмечал, что, начиная стихотворение, творец не вполне представляет себе, чем оно закончится. Иногда это завершение оказывается для самого автора неожиданным...

Следующая строфа прозаика и поэта Бахата Кенжеева начинается с философического, почти библейского раздумья о бренности мира и об оценке жизненного пути. Каждому - по делам его, кому - камень, кому - пряник:

...вроде снежного мякиша, вроде судьбы - не плачь,

всё проходит. Нужда научит: всякому за углом

обещают булыжник мерзлый, а может быть, и калач,

по делам его злополучным, читай - поделом

(«Если ртуть - суетливый аргентум...») ${ }^{220}$.

К концу стихотворения, мы видим, тональность меняется. Откуда появляется это поделом, содержащее в себе элемент злорадства? Может быть, потому, что дела все-таки оказываются злополучными? Но, скорее всего, оно спровоцировано выражением по делам, употребленным чуть ранее. Для поэта эти слова оказываются как бы синонимами, второе уточняет первое: по делам - читай поделом.

Как уже отмечалось, в ходе порождения текста смысловые и формальные факторы в сознании говорящего взаимодействуют. Для того, чтобы продемонстрировать многовекторный поиск и подбор номинаций в условиях постоянной активизации звукоряда, рассмотрим очередные два примера. Первый - фрагмент стихотворения Бориса Пастернака «Город» (1916 год):

Это черной божбою

Бьется пригород Тьмутараканью в падучей.

Это Люберцы или Любань. Это гам

Шпор и блюдец, и тамбурных дверец, и рам

О чугунный перрон. Это сонный разброд

Бутербродов с цикорной бурдой и ботфорт.

Это смена бригад по утрам. Это спор

Забытья с голосами колес и рессор.

Это грохот утрат о возврат. Это звон

Перецепок у цели о весь перегон...221

«Эпический мотив» города воплощается в картине вокзально-железнодорожной суеты. Любопытно, что в качестве «Тьмутаракани» выступают здесь Люберцы (город в Подмосковье) и Любань (городок в Белоруссии). В ранней редакции стихотворения упоминаются Подольск и Сибирь ${ }^{222}$ :

219 Бродский (1992, 2, с. 462).

220 Кенжеев (2011, с. 22).

221 Пастернак (1989, 1, с. 249).

222 Пастернак $(1989,1$, c. 512$)$. 
топос здесь не важен, важно время: «Всюду скорбь. Это наш городской гороскоп». Упоминание шпор и ботфорт наводит на мысль о войске, о кавалерии, но главное здесь - ощущение беспорядка, спешки, шума.

Инструментовка на взрывные согласные [б]/[п], [д]/[т], сонорные [р], [м], [н], а также [ц] на фоне гласного [у] (характеризующегося повышенной частотой по сравнению со средней величиной) не только создает общее впечатление хаоса, разноголосицы, гула и грохота, но и вызывает в сознании ассоциации с такими русскими словами, как барабан, таракан, тарарам, сумбур, бред, белиберда, бормотать, бранить, бренчать, тендер, трюм, центр, центнер, цербер, цедра, перец... Какие из этих слов актуализируются в теневой части сознания читателя, сказать трудно - это дело случая. Как известно, энтропия поэтического текста не только устраивает читателя, но и привлекает его. Но находить в этом отрывке анафонию вполне правомерно. Мозаичный образ города, пригорода, вокзала и перрона держится на нити созвучий. Они порождают целое ассоциативное поле, дополняющее явную картину.

Второй пример - уже анализировавшееся нами ${ }^{223}$ стихотворение Осипа Мандельштама «Куда мне деться в этом январе?» (1937 год). Приведем его целиком.

Куда мне деться в этом январе?

Открытый город сумасбродно цепок...

От замкнутых я, что ли, пьян дверей? -

И хочется мычать от всех замков и скрепок.

И переулков лающих чулки, И улиц перекошенных чуланы И прячутся поспешно в уголки И выбегают из углов угланы...

И в яму, в бородавчатую темь Скольжу к обледенелой водокачке И, спотыкаясь, мертвый воздух ем, И разлетаются грачи в горячке -

А я за ними ахаю, крича

В какой-то мерзлый деревянный короб:

- Читателя! советчика! врача!

На лестнице колючей разговора б!224

Стихотворение написано за неполные два года до гибели поэта. Мандельштам надломлен и не надеется уже на поворот к лучшему в своей

223 Норман (2003).

224 Мандельштам (1990, 1, с.236-237). 
судьбе. Но не касаясь здесь ни идейного (концептуального) строя стихотворения, ни использования в нем многообразных лексических и грамматических средств, обратим внимание только на возможные анафонические связи. Впрочем, употребленные поэтом определения (перекошенный, бородавчатый, обледенелый, мертвый, мерзлый, колючий) тоже достаточно выразительны в своем звуковом составе. Но главное - взаимодействие семантических и фонетических ассоциаций дает читателю основания обнаружить в тексте прямо не названные, но как бы подразумеваемые там лексемы (анаграммы или криптограммы).

К примеру, многочисленные слова, обозначающие процессы звучания (мычать, лающих, ахаю, крича), в комбинации с другими словами с педалированными [у], [л], [г] / [к] (переулков, чулки, улиц, чуланы, уголки, углов, угланы) позволяют «услышать» скрытую в тексте лексему гулкий (гулок).

Точно так же словоформы открытый, цепок, замкнутых, дверей, замков, скрепок, объединяемые общей семой 'отпирать/запирать', в одном контексте с фонетически выразительными оболочками чулки и колючей, инструментованными на [к] / [к'], [л] / [л'], [ч], могут навести читателя на «зашифрованную» лексему ключи. Если есть замки и замкнутые двери, то должны быть и ключи!

Совокупность словоформ город, грачи, в горячке, мертвый, деревянный, короб, разговора 6 позволяет «реконструировать» не названное прямо слово гроб...

Эти примеры демонстрируют взаимодействие механизмов порождения и восприятия текста: фонетические корреспонденции, с одной стороны, помогают поэту выбрать нужное слово, а, с другой стороны, они позволяют читателю увидеть в тексте больше, чем там сказано.

Изолированные, с системно-языковой точки зрения, лексемы вводятся в системные лексические отношения в тексте, но импульсом для этого послужил несемиотический фонетический фактор... Формальная, фонетическая, и содержательная, морфологическая и лексико-семантическая структуры поэтического текста находятся в отношениях взаимодополнения, вероятно, при определяющей роли фонетического оформления текста ${ }^{225}$.

Конечно, подобное проделанному нами «восстановление» слов и вообще все фоносемантические ассоциации - сфера и плод индивидуального, субъективного речевосприятия. И следует отдавать себе отчет в том, что даже если читатель выбирает какие-то из данных связей, то сам процесс их выбора вряд ли входит в светлое поле его сознания. Однако полностью исключать возможность такого дополнительного проникновения в текст

225 Соболева (2002, с. 95). 
нельзя. Поэтому, по словам Сергея Аверинцева, «Мандельштама так заманчиво понимать - и так трудно толковать» ${ }^{226}$.

Примечательно, что чрезмерное увлечение звукописью может со временем проходить и даже оцениваться автором отрицательно. Тот же Борис Пастернак после двух десятилетий поэтических экспериментов писал:

Есть в опыте больших поэтов

Черты естественности той,

Что невозможно, их изведав,

Не кончить полной немотой.

В родстве со всем, что есть, уверясь

И знаясь с будущим в быту,

Нельзя не впасть к концу, как в ересь,

В неслыханную простоту

$$
(\text { «Волны») })^{227} \text {. }
$$

А Владимир Набоков, строки которого про «злые узлы змей» мы только что цитировали, приводит в романе «Отчаяние» свой ранний стихотворный опус:

Хохоча, отвечая находчиво,

(отлучиться ты очень не прочь!),

От лучей, от отчаянья отчего,

От чего ты отчалила в ночь? -

и комментирует так: «Мое, мое, - опыты юности, любовь к бессмысленным звукам...» ${ }^{228}$. Таким образом, соотношение доли «формального» и «содержательного» компонентов в поэтическом творчестве может меняться не только от автора к автору, но и от периода к периоду.

Взаимодействие языковых уровней в процессе порождения поэтического текста приобретает креативную силу. Поясним этот тезис. С одной стороны, определенная свобода в выборе лексем, обусловленная влиянием звукоряда, стимулирует вариативность порождаемой синтаксической структуры, допуская и в этом отношении те или иные отклонения от нормы. С другой стороны, сквозная фонетическая инструментовка стиха ослабляет обязательность собственно грамматических связей: она принимает на себя значительную часть структурной организации текста.

Иными словами, особое внимание к формальной (звуковой) стороне произведения подталкивает поэта к большей свободе в использовании

226 Аверинцев (1990, с.64).

227 Пастернак (1989, 1, с. 381).

228 Набоков (1990, 3, с. 360). 
синтаксических и вообще грамматических средств. Б. Пастернаку несложно было сказать: «Орешник тебя отрешает от дня...» ${ }^{229}$, хотя отрешать от чего-то - явно архаичная конструкция, еще более странная при неличном субъекте; по сути, строка держится на созвучии орешник - omрешать, и эта связь самодостаточна. Но возьмем теперь поэта более традиционного и сдержанного в использовании версификационных средств - Сергея Есенина.

Опять я теплой грустью болен

От овсяного ветерка.

И на известку колоколен

Невольно крестится рука...

(«Запели тесаные дроги...») $)^{230}$.

Ненавязчивые звуковые переклички можно заметить и здесь: грустью [ст'] - известку [ст] - крестится [ст']; известку [ку] - колоколен [ко-ко] - рука [ка]; овсяного [ва] - ветерка [ве] - известку [в’о] - невольно [во]...

Метафорическое сочетание теплая грусть - значит, по-видимому, 'сердечная, душевная, мягкая грусть'. Овсяной ветерок - судя по всему, это 'ветерок, долетающий с овсяного поля'. А вот следующие строки требуют более подробного и сложного истолкования. У читателя они не вызывают никаких затруднений, но лингвистически они очень интересны. Эти строки означают: 'верующий человек невольно крестится (рукой), когда видит крест, венчающий собой колокольню церкви, окрашенную белой известью'. Причем обратим внимание: большая часть слов, использованных в толковании, в оригинальном тексте вообще не упоминается, а остается «за скобками»: это человек, церковь, крест, белый... Читатель должен восстановить в уме сложную семантическую структуру по ее «сухому остатку». Это то, о чем писал В.А. Звегинцев, призывая исследовать «грамматику умолчания» - процессы, протекающие в голове у говорящего человека ${ }^{231}$.

Процесс синтаксической компрессии, или стяжения (преобразования конструкции в формально более простую, но, вместе с тем, семантически более «емкую», насыщенную), органически связан с другим синтаксическим преобразованием - переносом, или повышением ранга слова (англ. rising). В приведенном примере это, в частности, крестится рука (из человек крестится (рукой)), на известку колоколен (из на колокольни, беленые известкой) и т.п. Механизмы компрессии и райзинга отработаны языковым коллективом как готовая техника и активно применяются в устной речи. Тут они, очевидно, служат экономии речевых усилий. Мы привычно говорим предварительные кассы вместо кассы по

229 Пастернак $(1989,1$, с. 207).

230 Есенин (1983, с. 49).

231 Звегинцев (1996, с. 171). 
предварительной продаже билетов, докторский совет вместо совет по защите докторских диссертаций, таблетки от головы вместо таблетки от головной боли, поеду в город вместо поеду в центр города, куртка Китай вместо куртка китайского производства и т. п. ${ }^{232}$ Компактные выражения соответствуют требованиям компьютерной эпохи. В поэтическом же тексте синтаксические преобразования служат иным целям. Они способствуют «остранению» (термин В. Шкловского) текста, насыщению его дополнительными смыслами. Впрочем, как отмечают исследователи, «коммуникативные признаки, общие для поэтической и разговорной речи, приводят к употреблению одинаковых конструкций и к некоторым сходным принципам построения речи» ${ }^{233}$, среди которых - и возможность «опускать смысловые звенья».

Так и в следующих, казалось бы, семантически совершенно прозрачных строках Владимира Луговского мы вправе усмотреть синтаксическую компрессию с продвижением слова «вверх», ближе к вершине грамматической структуры:

Нет, та, которую я знал, не существует.

Она живет в высотном доме, с добрым мужем.

Он выстроил ей дачу, он ревнует,

Он рыжий перманент ее волос целует

(«Та, которую я знал») $)^{234}$.

Он рыжий перманент ее волос целует значит: 'он целует ее рыжие волосы, испорченные перманентной завивкой'. Семантический элемент 'завивка' вообще исчез, поглотился структурой, а элемент 'перманент' поднялся на три уровня вверх. И это так похоже на обороты разговорной речи!

Благодаря расчету на со-творчество, сотрудничество, на взаимодействие с адресатом (читателем), поэтический текст приобретает 3-е измерение: он принципиально амбивалентен, многозначен, многослоен. Конечно, разные читатели могут извлечь из одного и того же текста различный контент, но поэта это не пугает. Более того, стихотворное произведение априори может рассматриваться как двуплановый, двуслойный текст, в котором, возможно, «зашифрованы» некие не названные прямо слова. Синтаксический перенос и стяжение, как мы только что видели, могут участвовать в механизме такого речепорождения. Но и фонетический строй стиха помогает найти в нем подтекст.

Более того, звуковые сопоставления могут становиться конструктивно определяющими, «смыслонесущими». Перешагнем через десятилетия

232 Норман (2012в, с. 4-5).

233 Ковтунова (1986, с. 191).

234 Луговской (1966, с. 277). 
и приведем пример вполне современный: начало текста песни барда Олега Митяева «Француженка»:

Неровность вычурная крыш течет за горизонт.

Семнадцатый квартал. Париж. Чуть вздрагивает зонт... 235

Трудно не заметить тут инструментовку на согласные: [р] - [в] - [н] - [д]/ [т]... Что кроется за этими звуками, какие еще слова? Нервно? Тревога? Верность? Ревность? Травма? Вранье? Отрава?.. Вряд ли можно говорить здесь в прямом смысле о какой-то криптографии, о зашифрованной в данном тексте анаграмме. Однако общая атмосфера неуверенности, тревожного настроения не только создается нагромождением указанных консонантов, но и проецируется в сознании на неожиданную подборку подразумеваемых слов. Эта семантическая сложность поддерживается окказиональной комбинаторикой: вычурная неровность, неровность течет, зонт вздрагивает... Для песенного жанра данные строки, несомненно, сложны, но их эстетический эффект базируется на комплексном использовании языковых средств (разумеется, вместе с музыкальным рядом).

Говоря о синтаксических особенностях современной лирической поэзии, стоит обратить внимание на активное использование в ней номинативных конструкций. Мы только что могли это наблюдать в случае Семнадцатый квартал. Париж... Но односоставные предложения могут держать на себе внимание читателя довольно долгое время, в том числе в метафорически насыщенных строках, например:

Или чучело речи в развалинах телеканала,

или шкаф с барахлом, как симметрия с выбитым глазом, или кафельный храм, или купол густого вокзала, или масть, или честь, оснащенная противогазом. Одноместный колпак как гитарная радуга барда, или колокол братства с надтреснутой нотой в рыданье, ветровое стекло, осененное нимбом с кокардой над стальными усами, проросшими всем в назиданье...

(И. Жданов. «Ниша и столп») ${ }^{236}$.

В уже цитированной книге И. И. Ковтуновой говорится:

Тенденция к заполнению композиционного пространства стиха односоставными предложениями возникла в русской лирической поэзии во второй половине XIX века. Среди односоставных предложений особенно показательны и интересны номинативные и инфинитивные структуры как особые смысловые эквиваленты двусоставных предложений, содержащие только предикат ${ }^{237}$.

235 Митяев (1990).

236 Жданов (1991, с. 80).

237 Ковтунова (1986, с. 156). 
«Достоинство» номинативных предложений для стихотворного ряда заключается не только в их компактности, но и в том, что они позволяют переключить внимание читателя с синтаксической организации стиха на лексическую и звуковую.

Мы видим, как фонетика образует с лексикой и синтаксисом сложное целое, совокупно работающее на создание эстетического эффекта. Представляет интерес следующее наблюдение над особенностями творческой манеры Осипа Мандельштама:

Мандельштам, в противоположность Пастернаку, объяснял Эмме Герштейн свой метод как «мышление опущенными звеньями» - то есть отказ от цепочки: рядом ставятся первое и последнее слово прихотливого ассоциативного ряда, а прочее читатель волен домысливать сам. Мандельштам еще называл это "отдаленным знакомством слов" - и слова в его стихах в самом деле едва знакомы, тогда как у Пастернака они намертво связаны смыслом и звуком... ${ }^{238}$.

Действительно, в поэзии О. Мандельштама полно примеров, когда сочетания слов скрывают за собой прихотливые цепочки ассоциативных связей. (Тут мы возвращаемся к теме опосредованных реакций в психолингвистическом эксперименте.) Рассмотрим под этим углом зрения два стихотворения поэта, относящихся к разным периодам творчества.

Московский дождик (1922)

...Он подает куда как скупо

Свой воробьиный холодок -

Немного нам, немного купам,

Немного вишням на лоток.

И в темноте растет кипенье -

Чаинок легкая возня, -

Как бы воздушный муравейник

Пирует в темных зеленях.

И свежих капель виноградник

Зашевелился в мураве, -

Как будто холода рассадник

Открылся в лапчатой Москве! 239

Содержание стихотворения сводится к импрессии, к передаче общего настроения: Москва, зеленая зона (купы, зеленя, мурава), мокрая погода (дождик, кипенье, капли), прохлада (холодок, холод)... Но детали требуют истолкования и домысливания. Прежде всего обращают на себя внимание словосочетания воробьиный холодок, воздушный муравейник, лапчатая Москва.

238 Быков (2010, с. 454).

239 Мандельштам (1990, 1, с. 144). 
Что такое воробьиный холодок? Воробьи «нахохливаются» при плохой погоде (плюс звуковая перекличка: холодок - хохолок)? Или же имеется в виду переносное значение прилагательного воробьиный: 'малый, слабый, незаметный’ (ср. воробьиный шаг, скок, нос, клюв...)? В НКРЯ с этим прилагательным зафиксировано 50 документов, 56 вхождений, и в большинстве случаев это 'что-то маленькое ${ }^{240}$. В любом случае «знакомство» слов холодок и воробьиный опосредовано каким-то третьим звеном (то ли это народная примета, то ли малый размер и т.п.).

Что имеется в виду под выражением воздушный муравейник? Очевидно, это о мороси, мелких каплях, рассеянных в воздухе. Причем появление лексемы муравейник спровоцировано рядом находящимся словом мурава (вот она, поэтическая этимология!) И хотя капли, в принципе, летят вниз, а кипенье, возня чаинок - беспорядочное движение, хаос, но идея муравейника эти виды движения объединяет.

Еще одна растительная метафора рядом - капель виноградник. Но виноградник - это 'участок земли, засаженный виноградными кустами'. Здесь же имеется в виду множество виноградин (гроздь?). Может быть, этот виноградник навеян предыдущим муравейник? Ассоциация муравейник + (виноградины) $\rightarrow$ виноградник?

Наконец, что значит лапчатая Москва? Имеются ли в виду ели с их лапами? Но упоминаемые купы предполагают присутствие в поле зрения не хвойных, а лиственных деревьев (тем более, что рядом фигурируют вишни, зеленя, мурава...). Вряд ли стоит здесь видеть и отсылку к созвучному выражению лапотная Москва (Русь): никакого пренебрежительного или уничижительного оттенка в стихотворении нет. Скорее всего, отгадку следует видеть в воробьях: это у них - лапки! (Симптоматично, что большинство из 35 документов, 40 вхождений на лапчатый в НКРЯ содержат выражение гусь лапчатый!241) Итак, выявляется цепочка из трех звеньев: воробьиный - (лапки воробьев) - лапчатая Москва.

Любопытно, что в ранней редакции стихотворения приводится первая строфа, позже опущенная. Она кое-что проясняет:

Бульварной Пропилеи шорох -

Лети, зеленая лапта!

Во рту булавок свежий ворох,

Дробями дождь залепетал ${ }^{242}$.

Слово лапта в этой строфе фонетически предвосхищает последующую лапчатую Москву, а прилагательное бульварный локализует ситуацию (тут, на бульваре, очевидно, и торгуют вишнями, на лоток с которыми попадает дождь). А в примечании к тому же стихотворению в издании

240 НКРЯ (01/11/2018).

241 НКРЯ (10/11/2018).

242 Мандельштам (1990, 1, с. 382). 
«Большой серии Библиотеки поэта» дается отсылка к очерку О. Мандельштама «Холодное лето» (1923):

Словно мешок со льдом, который никак не может растаять, спрятан в густой зелени Нескучного, и оттуда ползет холодок по всей лапчатой Москве [...] Жить нам в Москве [...] с воробьиным холодком в июле ${ }^{243}$.

К этому можно добавить, что мешки со льдом часто укрывают еловыми лапами - и это еще один «мостик» к объяснению непростых для понимания фрагментов стихотворения.

Интересно, что Валентин Катаев в биографической повести «Алмазный мой венец» подтверждает обстоятельства, которые привели к созданию «Московского дождика»:

Ветер качал купы разросшихся, давно уже не стриженых деревьев, кажется, лип, а может быть, тополей, и мне чудилось, что они тоже колобродят, обреченные на сруб. Глядя в окно на эту живую, шевелящуюся под дождем листву, Щелкунчик [прозвище Мандельштама в этой повести - Б. Н.] однажды сочинил дивное стихотворение, тут же, при мне, записанное на клочке бумаги, названное совсем по-детски мило “Московский дождик"244.

Еще любопытнее, что выражения из стихотворения Мандельштама попадают (осознанно или неосознанно) в современные тексты. Так, у М.В. Панова, замечательного русского лингвиста, о котором уже шла речь, есть и такие стихотворные строки:

Смерч высосал пруд, завертел -

И рассыпал лапчатым дождиком

(«Лягушками, бусами») ${ }^{245}$.

Может быть, дождь потому «лапчатый», что смерч поднял в небо лягушек из пруда? Но не исключено, что тут присутствует и подспудная аллюзия к мандельштамовскому стихотворению.

А в других, прозаических, текстах можно встретить выражение воробьиный дождь - хотя словари его (в отличие от воробьиной ночи) не фиксируют. Пример:

И был ротный - с полпальца, давно отступивший и позабывший про нас. И солдаты, рассыпавшиеся по степи, как ржаное крошево, которое, накрапывая, клевал воробьиный чахлый дождь (О. Павлов. «Степная книга») ${ }^{246}$.

Идиолект писателя, а в особенности поэта, формируется совокупностью наиболее частотных и характерных слов и выражений. Существуют ис-

243 Мандельштам (1974, с. 282).

244 Катаев (1981, с. 80).

245 Панов (2001, с. 97).

246 Павлов (1998). 
следования, со всей определенностью моделирующие идейно-концептуальный строй художественного текста через наиболее частотную знаменательную лексику (см. уже классический образец - работу Ю.И. Левина $\left.{ }^{247}\right)$. И Мандельштам не раз возвращается к излюбленным образам. В частности, в стихотворении «Полночь в Москве. Роскошно буддийское лето...», под которым стоит дата 1931 год, мы встречаем такие строки:

Бывало, я, как помоложе, выйду

В проклеенном резиновом пальто

В широкую разлапицу бульваров...

И пахло до отказу лавровишней...

Куда же ты? Ни лавров нет, ни вишен...

Уже светает. Шумят сады зеленым телеграфом...

Он с Моцартом в Москве души не чает -

За карий глаз, за воробьиный хмель...

Передают с квартиры на квартиру

Конвейером воздушным сквозняки... ${ }^{248}$

Здесь представляют интерес не только разлапица бульваров (ср. лапчатый и бульварный в предыдущем стихотворении), лавровишня (ср. вишни там же) и воробьиный хмель (ср. воробьиный холодок), воздушный конвейер (ср. воздушный муравейник), но и не чает (как бы отсылка к чаинкам), и сквозняки (аллюзия к возне) и т. Д. Поэт живет в своем словесном пространстве, в своем хронотопе и смотрит на мир через призму своего идиолекта.

Приведем теперь второе стихотворение Осипа Мандельштама, оно датировано 1937 годом и не имеет отдельного названия.

Не сравнивай: живущий несравним.

С каким-то ласковым испугом

Я соглашался с равенством равнин,

И неба круг был мне недугом.

Я обращался к воздуху-слуге,

Ждал от него услуги или вести,

И собирался в путь, и плавал по дуге

Не начинающихся путешествий...

Где больше неба мне - там я бродить готов,

И ясная тоска меня не отпускает

247 Левин (1966).

248 Мандельштам (1990, с. 177-178). 
От молодых еще, воронежских холмов -

К всечеловеческим, яснеющим в Тоскане ${ }^{249}$.

Стихотворение - о личности, рвущейся к свободе. С «равенством равнин» приходится мириться, хотя оно пугает. Небо притягательно, но недостижимо; этой мечтой впору заболеть (недуг). Воздух - проводник к свободе, к небу, но желанные путешествия так и не осуществились. Воронежские холмы доступны, но настоящие, «всечеловеческие», - далеко отсюда, в Италии, в Тоскане.

И здесь мы ощущаем созвучия, пронизывающие ткань стихотворения: не сравнивай - не сравним, неба круг - недугом, слуге - услуги, тоска - отпускает, ясная тоска - яснеющим в Тоскане.

Но при всей прозрачности архитектоники некоторые фрагменты структуры нуждаются в комментариях.

С кем несравним живущий? Поскольку никакого объекта сравнения не названо, приходится восстановить опущенное звено - «другие люди»: (несравним - (другие люди) - живущий) или же понимать несравним как 'уникален'. И логично отнести эту характеристику к личности автора.

Что значит оксюморонное ласковый испуг? Примиренчество или своего рода душевный мазохизм? Испуг бывает легким или сильным, первоначальным или внезапным... Ласковым чаще всего бывает голос, тон, взгляд (такие сочетания чаще других дает НКРЯ ${ }^{20}$ ). Это же качество, заметим, свойственно детям и детенышам (ср. выражения ласковый мальчик, ласковый теленок, ласковый котенок...), и тем же субъектам присуще такое качество, как пугливость. Может быть, сочетание ласковый испуг возникает с участием этого парадигматического посредника: ласковый - (пугливый) - испуг?

Упомянутое равенство равнин можно понимать двояко. Либо равенство равнозначно ровность 'плоскость' (промежуточная формальная ассоциация), либо это 'одинаковость', тогда восстанавливается цепочка равенство - (одинаковость) - равнины, и общий смысл получается: «Равнина есть равнина»). В смысловом отношении эти варианты не так уж далеки друг от друга, но и тот, и другой подразумевают некое промежуточное звено.

Выражение Неба круг был мне недугом выглядит не совсем по-русски. Правильно было бы сказать Неба круг был мне неведом ('недостижим'), либо Неба круг был моим недугом ('страданием'). Возможно, контаминация этих двух вариантов (восстанавливаемых нами с деликатным пред-

249 Мандельштам (1990, 1, с. 232).

250 НКРЯ (10/07/2019). 
положением) и дала третий вариант, вошедший в стихотворение. Впрочем, в современных поэтических текстах субъект отношения, выраженный дательным падежом, встречается нередко, ср.:

Там дева-мгла склоняется над книгой исхода, молдаван, отец семье, болтает с эфиопом на скамье...

(Б. Кенжеев. «Уеду в Рим и в Риме буду жить...») $)^{251}$.

Как видим, ассоциативная цепочка слов может опираться на разную синтаксическую структуру, но для адресата-читателя она подготавливает имплицитную информацию, подтекст, проникновение в который требует дополнительных интеллектуальных усилий и вознаграждается дополнительным эстетическим эффектом.

Вернемся к творчеству Бориса Пастернака. В приведенной выше цитате из биографического романа Дмитрия Быкова стихотворные приемы О. Мандельштама противопоставляются технике Б. Пастернака - у последнего «все вещи - в тесном родстве и непрестанном диалоге» 252 . Однако, на наш взгляд, у Пастернака, особенно в раннем творчестве, также можно найти немалое количество примеров «мышления опущенными звеньями». Возьмем начало стихотворения «Ты в ветре, веткой пробующем...»:

Ты в ветре, веткой пробующем,

Не время ль птицам петь,

Намокшая воробышком

Сиреневая ветвь!

У капель - тяжесть запонок,

И сад слепит, как плес,

Обрызганный, закапанный

Мильоном синих слез...253

Первая строфа, судя по всему, это обращение к ветке сирени. Конечно, для лингвиста мало чести в том, чтобы «музыку разъять, как труп», но попытаемся это сделать. Синтаксическая структура здесь вырисовывается следующая: 'сиреневая ветвь, намокшая, как воробышек, проявляется в ветре, который веткой пробует, не время ли птицам петь'. Очевидно, и здесь восстанавливаются некоторые промежуточные смысловые звенья: ветвь, намокшая, как - (намокает под дождем) - воробышек; ветер - (качая) - ветку, пробует... Некоторое косноязычие - поэзии не помеха, оно сглаживается изящными звуковыми перекличками: [вет] - [вет] (ветре - веткой), [кш] - [шк] (намокшая - воробышком), [врем'] - [ренев] (время - сиреневая)... Вторая строфа синтаксически прозрачна, но и в ней

251 Кенжеев (2011, с. 58).

252 Быков (2010, с. 454).

253 Пастернак (1989, 1, с. 118). 
сравнение капель с запонками, сада с плесом, брызг со слезами нуждается в подкреплении звукорядом: капель - закапанный, слеп(ит) - плес, запонок - закапанный, а синий возвращает к сиреневому... И в целом стихотворная стихия Б. Пастернака - это безбрежное море метафор (основанных на сравнениях), подкрепляемое звуковыми перекличками и не отвергающее синтаксических преобразований.

А в следующих строфах - фрагменте стихотворения «Приближение грозы»- речь идет о громе:

...Как допетровское ядро,

Он лугом пустится вприпрыжку

И раскидает груду дров

Слетевшей на сторону крышкой.

Тогда тоска, как оккупант,

Оцепит даль. Пахнёт окопом.

Закаплет. Ласточки вскипят.

Всей купой в сумрак вступит тополь...254

У Пастернака вообще довольно много стихотворений о ненастье - о грозе, громе, дожде... В данном случае несколько неожиданные аллюзии к петровской эпохе и Русско-шведским войнам объясняются тем, что стихотворение посвящено историку Я.З. Черняку.

В первой строфе отражается громыханье грома: [тр] - [др] - [пр'] - [пр] - [гр] - [др] - [кр]... Во второй строфе слышится начало дождя: это цепочка [куп] (оккупант) - [коп] (окопом) - [кап] (закаплет) - [кип] (вскипят) [куп] (купой), с одновременным нарастанием свистящих согласных.

Что же касается синтаксической структуры, то гром, раскидывающий груду дров крышкой, выглядит несколько странно. Скорее бы тут ожидалась сочинительная конструкция: гром раскидал груду дров, и (с чего-то там) слетела крышка. Или сравнение: раскидал груду дров, как (сорвал с чего-то) крышку. Какой-то участник ситуации здесь не назван, нуждается в мысленном восстановлении. Допетровское ядро - это снаряд, выпущенный из старинной пушки. В сознании образуется ассоциативная цепочка ядро - (пушка) - (выстрел) - гром. В следующей строфе тоже напрашивается связующее звено: тоска, как оккупант - (стремящийся все захватить) - оцепит даль... Далее, выражение ласточки вскипят означает, очевидно, внезапный и бурный взлет стаи птиц: ласточки (внезапно взлетят, как будто вода, с шумом) - вскипит... А Всей купой в сумрак вступит тополь подразумевает смысл «фон для дерева - потемневшее небо». Все эти предположения и мысленные вставки читатель, естественно, должен проделать сам. Кстати, обращает на себя внимание лексика, используемая Пастернаком в цитированных стихотворениях: она удивительным

254 Пастернак (1989, 1, с. 248). 
образом напоминает лексику, уже знакомую нам по приводившимся текстам Мандельштама: воробышек, капать, капли, вскипеть, купа, тоска... Но многие слова здесь состоят друг с другом в «отдаленном знакомстве». Ю. И. Левин замечал, что случаи, когда «опущенное слово не восстанавливается по контексту - наиболее характерный и распространенный» прием в сборнике «Сестра моя - жизнь» 255 . А Д. Быков в уже цитированной книге высказывается о метафорике Б. Пастернака почти саркастически:

Деревья машут поезду, гром фотографирует на память, хлопья шепчут, теченье ест зарю, иногда происходит нечто вовсе уж невразумительное - «сиренью моет подоконник продрогший абрис ледника», не поймешь, кто кого моет, - но разномасштабные и разнонаправленные действия не прерываются ни на секунду 256 .

Конечно, критик имеет право на свою точку зрения. Но ведь от поэтического текста не требуется информационной конкретности и логической стройности - его ценность в другом. О.И. Северская так пишет об одном современном стихотворце: «...В другом примере нельзя точно сказать, о чем идет речь, какие выражения употребляются в прямом, а какие - в переносном смысле, нельзя отделить реальность от ее образа» ${ }^{257}$. Тем более это применимо к Б. Пастернаку, поэзия которого оказала огромное влияние на всю русскую литературу, а ее самобытность, оригинальность в значительной степени обязаны собой указанным характеристикам. Бесконечные метафоры, окказиональные словосочетания («отдаленное знакомство слов») создают имплицитную информацию, обладающую эстетической ценностью.

Борис Пастернак и Осип Мандельштам - современники и в равной степени, несмотря на их различную судьбу, вершины русской поэзии. И при всех идейно-эстетических различиях в их творчестве, они прибегают к одним и тем же языковым техникам, взаимодействие которых составляет универсальную черту поэтического мастерства.

Подводя итоги, скажем: связи, существующие между словами в сознании, имеют сложную природу и нередко образуют многочленные цепочки. Массу реакций из словарей ассоциативных норм можно объяснить только восстанавливая опущенные промежуточные звенья. Это один из объектов психолингвистики.

В то же время мы видим, что и в ткани стиха речевыми партнерами оказываются слова, изначально не связанные друг с другом по смыслу. Восприятие и понимание таких цепочек читателем нуждается в восстановлении

255 Левин (1966, с. 211).

256 Быков (2010, с. 104).

257 Северская (2019, с. 138). 
подразумеваемых смысловых звеньев. Существенную роль в данном процессе играет звукопись, которая принимает на себя функцию параллельной - поддерживающей или даже доминирующей - линии этих ассоциаций. Речь идет о прямых звуковых повторах, об анафонии и анаграммах.

Восстановление промежуточных звеньев межсловных связей, или ассоциативных «мостиков», выпадающее на долю читателя или слушателя, соответствует общим закономерностям речевой деятельности человека. Поэт же, «устами которого говорит язык», интуитивно и плодотворно использует весь арсенал этих языковых средств. 


\title{
Глава 4. О борьбе строки с предложением (и о смысле невыраженном, но реконструируемом $)^{258}$
}

Основной единицей синтаксиса по праву считается предложение. При наличии большого количества классификационных определений предложения, его признаки как предикативной единицы закреплены в наивном сознании носителя языка и регламентируют особенности речевого поведения последнего. Это значит - в огромном, подавляющем большинстве случаев высказывания, производимые говорящим, соотносятся со стандартными моделями предложений, заложенными в его памяти. Именно на фоне этих стандартных ситуаций и выделяются такие «отклонения», как неполные, незаконченные высказывания, синтаксически нечленимые высказывания (междометные и т.п.), а также более сложные случаи вроде телеграфного стиля, отражающего неупорядоченный поток сознания, и т.п. В.Г. Адмони, проанализировавший массив «разовых» высказываний в устной немецкой речи, приходил к следующему выводу:

...Любая фрагментарность, «структурная размытость», грамматическая «алогичность» высказывания позволяют все же найти те грамматически закрепленные структуры, к которым (или к проекциям на которые) восходят все без исключения своеобразные черты спонтанной разговорной речи, вообще разового высказывания ${ }^{259}$.

Что же это за «грамматически закрепленные структуры»? Это - синтаксические модели, хранящиеся в памяти языкового коллектива структурные схемы предложений. Пояснение из той же работы В.Г. Адмони:

\begin{abstract}
Конечно, в бесчисленных разновидностях своих речевых проявлений высказывание может чрезвычайно далеко отойти от исходной структуры предложения... Но всегда, во всех без исключения случаях, если мы остаемся в пределах человеческого языка, обнаруживаются хотя бы отдаленные связи между любыми формами речевого высказывания и типологией предложения в каждом языке 260.
\end{abstract}

Итак, предложение есть способ и инструмент организации речи. Но этот тезис безусловно применим только к прозаической речи (наиболее очевидно - к институциональной, менее очевидно - к обиходной письменной, наименее очевидно - к устной разговорной). Однако в поэтической

258 В основе раздела - переработанная и дополненная статья Б.Ю. Нормана, принятая к публикации в 2020 г. научным журналом «Известия Уральского федерального университета» со ссылкой на поддержку Немецкого научно-исследовательского общества (DFG), «Русскоязычная поэзия в транзите»; Трирский университет, Германия, FOR 2603.

259 Адмони (1994, с. 6о).

260 Адмони (1994, с. 44). 
речи роль предложения как способа организации текста и его основной единицы слабеет, отходит на второй план. В этих особых дискурсивных условиях, определяемых эстетической функцией, в дело, как известно, включаются иные факторы: размер (длина строки в слогах), ритм (соотносящийся с физиологическими особенностями дыхания), анафония (звукопись, т.е. концентрация определенных элементов плана выражения) и рифма (основанная на звуковом повторе). В письменных поэтических текстах строка вообще оказывается доминирующим средством их организации. Точнее, «борьба» строки и предложения в сознании читателя оборачивается разными результатами, но обычно «побеждает» строка - до тех пор, пока формировавшуюся смысловую гипотезу не приходится перестраивать под давлением грамматических правил. Именно строка позволяет читателю ощутить заданный стихотворный размер, расставить должным образом ударения в словах и сконструировать в сознании предварительный смысловой образ.

Вообще соотношение грамматики и метрики, предложения и строки в поэтическом тексте весьма сложно. Перечислим только некоторые экстремальные случаи. Строка сохраняется, хотя предложение (составляющее ее содержание) по концептуальным или цензурным соображениям удаляется. Строка повторяется (рефреном), хотя ее содержание уже известно читателю. Предложения в соседних строках строятся по одному структурному образцу (явление синтаксического параллелизма известно и прозаическим текстам, но в поэзии встречается значительно чаще). Можно сказать, что строка и предложение (или его значимая структурная часть - синтагма) здесь лишь в идеале соответствуют друг другу. На практике же метрическая организация стиха диктует свои порядки.

Граница строки (стиха), обусловленная заданным размером, связывается в сознании читателя с определенными ожиданиями: «Стихотворная строка может играть роль особого образца, организующего восприятие благодаря своим сущностным характеристикам ${ }^{26}$. Эти характеристики - ритмическая организованность, смысловая цельность и психологическая значимость - несомненны, если обратиться к массовому языковому сознанию. В недавно проведенном исследовании были обработаны поисковые запросы к системе Яндекс, посвященные русской поэзии. Анализ 34 млн запросов за год (апрель 2014 - март 2015) показал: из авторов, разумеется, на первом месте - Пушкин, за ним, с большим отрывом, идут Лермонтов, Есенин, Некрасов, Блок... Из более близкого к нам времени - Маршак, Бродский, Высоцкий, Пастернак... Интересно, что «чаще всего, когда ищут стихотворное произведение, в поиске набирают его название... Но в

261 Лузина $(1985$, с. 167). 
некоторых произведениях есть строки, которые известны людям даже больше, чем название, и тогда в запросе указывают именно их» ${ }^{262}$.

В частности, запросы к тексту «Евгения Онегина» формулировались не только по названию романа или в виде стандартных предложений, типа Любви все возрасты покорны или Мечты, мечты, где ваша сладость, но и в виде таких коллокаций: Мой дядя самых честных правил или Татьяна русская душою, сама не зная почему... Именно строки (а не предложения) западают читателям в память!

Простые и наглядные проявления самодостаточности строки как единицы поэтического текста мы находим в оглавлениях стихотворных сборников. Дело в том, что если автор не снабжает свое произведение специальным заголовком, то оно в оглавлении обозначается по первой строке. А эта строка далеко не всегда представляет собой законченное предложение; часто это его обрывок или вообе набор слов, осмысленность которому придаст только следующая часть текста. В частности, среди стихотворений Сергея Есенина есть такие, как: «Дымом половодье...», «Там, где капустные грядки...», «Порою вновь к твоим ногам...», «В лунном кружеве украдкой...», «Тучи с ожерёба...», «Хорошо под осеннюю свежесть...», «В час, когда ночь воткнет...» и т.п. ${ }^{263}$ Особые дискурсивные условия - стихотворный текст, отсутствие авторского заглавия, «представительская» функция в оглавлении - придают строке главенствующую и вообще исчерпывающую роль. Структурные же свойства предложения отступают при этом на второй план.

Характерны также фрагменты стихотворных текстов, которые осмысливаются именно благодаря разбиению их на строки. Это значит, что синтаксическая структура высказываний не ощущается в должной мере, лексические значения слов недостаточны, чтобы между ними установить безусловные связи, - и тогда на помощь приходит строка с ее делимитативной функцией. Это касается и классических текстов, ср.:

Мне в сумерках ты всё - пансионеркою,

Всё - школьницей. Зима. Закат лесничим

В лесу часов. Лежу и жду, чтоб смерклося.

И вот - айда! Аукаемся, кличем

(Б. Пастернак. «Мне в сумерки ты всё - пансионеркою...») $)^{264}$

Как понимать - Закат лесничим в лесу часов? Конечно, можно попытаться восстановить исходную для говорящего семантико-синтаксическую структуру (например: 'закат - как лесничий в лесу: следит за часами - пока не стемнеет...' и т.п.). Но читателю проще принять деление на строки за членение на смысловые отрезки и следовать ему.

262 Если не Пушкин, то кто: какие стихи ищут в интернете (2015).

263 Есенин (1983).

264 Пастернак (1989, 1, с. 193). 
Особенно важна функция строки в текстах современного авангарда. Здесь синтаксические связи между словами отходят на второй план, знаки препинания и заглавные буквы зачастую отсутствуют, а деление на строки сохраняется. «Рассыпчатость», хаотичность словесной структуры, очевидно, скрывает за собой некие концептуальные установки автора, но текст все равно должен быть каким-то образом организован - и эта обязанность в таком случае ложится на строкоделение, иногда в совокупности с ритмом и/или рифмой. Приведем сначала для примера отрывок из стихотворного цикла Алексея Парщикова:

У нас есть интуиция - избыток самих себя. Астральный род фигур, сгорая, оставляющих улиток.

В деньгах избытка нету. Бурных кур, гуляющих голландский гульден, где в бюстах королевская семья, по счету столько, сколько нужно людям, расхаживают, очи вечности клюя.

Купюры - замеревшие касания, глаза и уши заместить могли б.

Ты, деньги, то же самое для государства, что боковая линия для рыб

$$
\text { («Деньги») })^{265} \text {. }
$$

Это стихотворение довольно сложно для понимания, и лексика тому способствует, но отдельные его элементы с грамматической точки зрения выглядят просто странно. То, что в прозаическом тексте показалось бы небрежностью или косноязычием (куры гуляют гульден, в бюстах семья, замеревшие касанья, ты - деньги и т.п.), в стихотворном «списывается» на иную, особую природу поэтического дискурса.

Следующий пример, из поэзии Юлия Хоменко:

довольно солнечный денек

береза думает довольно

стоять по стойке смирно вольно

качнусь под ветром вон пенек

и тот волне весенней неги

поддался и пустил побеги

не говоря уже про птиц

пятьсот и более границ

превозмогли в свои пенаты

летя гортанны и пернаты

(«Небо в перьях») $)^{266}$.

265 Парщиков (2014, с. 98).

266 Хоменко (2018, с. 84-85). 
И здесь по грамматике, как говорится, могут быть вопросы. Каковы отношения между словами смирно и вольно? Как понимать выражение превозмогли в свои пенаты (очевидно, летя в свои пенаты)? Можно ли сказать «Они летят гортанны»? Можно ли от относительного прилагательного пернатый образовать краткую форму пернат? Но деление на строки (в сотрудничестве с ритмом и рифмой) скрадывает эти вопросы - для современной поэзии это уже привычно. Согласимся с критиком:

Поэтому ошибки дикторов или журналистов так заметны и так активно обсуждаются; в отношении поэтов этого не заметно - не столько потому, что у поэтов более развито языковое чутье: от поэтического слова не ожидается «школьная» правильность ${ }^{267}$.

Бывает, что к основаниям грамматической свободы поэта прибавляется ироническая составляющая или то, что сегодня даже в научной литературе именуют термином стёб.

Вот скажем наш народ советский

Иль скажем русский наш народ

Иль скажем наш народ еврейский

Или еще какой народ

Сказать-то мы конечно скажем

Чего уж право не сказать

Но что мы этим самым скажем

А скажем то что не понять

Что скажем

(Д. Пригов. «Банальное рассуждение на тему о национальной гордости» $)^{268}$.

Но строка, заметим, остается важнейшим знаком и инструментом поэтического дискурса. Только разбивке на строки обязан собою свободный стих, или верлибр, - иначе его трудно было бы отличить от прозы, ср. пример:

брошенные яблони в поле

на краю леса

продолжают плодоносить

антоновка

штрифель

стоят так бок о бок

посреди заросшего

высокой травой поля

к ним подступает болото

яблоки падают в траву

хрустят под ногами

дом хозяина разобрали

кругом ни души

267 Абдуллаев 2018, с. 17).

268 Пригов (1997, с. 126). 
только изредка

пролетит в небе ястреб...

(А. Коровин. «Тульское захолустье») $)^{269}$.

Если вернуться к стихотворениям, созданным в классическом ключе, то в большинстве случаев они следуют неписаной норме: строка должна содержать в себе предложение или же его структурную часть (синтагму). Конечно, и здесь в процессе речетворчества происходят какие-то преобразования: словосочетания «стягиваются» до одного элемента, слова попадают не «в свою» позицию, нарушаются правила глагольного управления и т.п. Но распознаваемые процессы семантико-синтаксических трансформаций, произошедших в сознании говорящего, не отменяют читательского доверия к строке как единице восприятия. Приведем очередной пример.

Я учился траве, раскрывая тетрадь,

И трава начинала как флейта звучать

(А. Тарковский. «Я учился траве...») $)^{270}$.

Учиться можно рисованию, иностранному языку, бальным танцам и т.д. - это значит 'набираться знаний', приобщаться к некоторой интеллектуальной или культурной сфере. А траву как природный объект можно изучать, исследовать. Учиться и изучать различаются не столько составом своих лексических сем, сколько особенностями синтаксического поведения ${ }^{271}$. И в высказывании Я учился траве можно усмотреть контаминацию, неправомерное смешение этих смыслов: учиться чему-то (например, рисованию) и изучать что-то (например, траву). Но строка Я учился траве, раскрывая тетрадь нейтрализует, стирает противопоставление отношения и объекта действия, отражая некий единый процесс приобщения к природе.

А в следующей цитате глагол помолчать, попадая в один сочинительный ряд с полечить и поотмаливать, окказионально приобретает переходность:

Помолчи меня, полечи меня, поотмаливай,

Пролей на меня прохладный свой взор эмалевый...

(В. Полозкова. «Пшшш») $)^{272}$.

Строка замыкает ряд из трех глаголов, заставляя воспринимать их как смысловое целое, почти как синонимы. Можно тут усмотреть и более сложные семантико-синтаксические преобразования, вроде компрессии («Помолчи [рядом со мной, не трогай] меня»), но наше решение о влиянии управления соседних глаголов выглядит более простым.

269 Коровин (2018, с. 13).

270 Тарковский $(1982$, с. 50).

271 Норман (2018, с. 66).

272 Полозкова (2012, с.133). 
Впрочем, и мысль о скрытой компрессии (вспомним недавно приводившийся пример из Сергея Есенина «И на известку колоколен...») не безосновательна. Поскольку строка в стихотворном тексте лимитирована количеством слогов, то это вынуждает поэта к лаконизму, к компактности, к плотности словесной упаковки. В качестве примера приведем еще строфу из стихотворения А. Парщикова «Львы»:

Львы. Их жизнь - дипломата,

их лапы - левы, у них две головы.

Со скоростью шахматного автомата

всеми клетками клетки овладевают львы ${ }^{273}$.

Если попытаться приблизительно восстановить ее «полный» смысл, то мы получим примерно следующее (да простит поэт лингвисту восстанавливаемые в скобках фрагменты): ‘львы. Их жизнь [сложна, как жизнь] дипломата. [Кажется, когда они в движении, что] их [обе] лапы - левы, [что] у них две головы. Со скоростью [компьютерного] шахматного автомата всеми клетками клетки, [в которую они заключены], овладевают львы'. Конечно, читатель может домыслить иной образный фон, представить себе иную исходную (полную) семантическую структуру. Но ту или иную смысловую гипотезу, тот или иной образ он должен в своем представлении создать. Способ соединения образа с реальностью неизбежно требует от читателя хотя бы минимальной лингвистической интерпретации. Вместе с тем, ясно, что никакая стихотворная строфа не способна вместить в себя развернутое описание, подобное тому, что было приведено выше: тут вступает в действие «грамматика умолчания».

Последний пример может послужить поводом для еще одного наблюдения. Поэтическая речь предпочитает союзной связи между предложениями - бессоюзную. Одна из причин этого только что названа: это ограниченность поэта размером, длиной строки. Вторая причина - бессоюзная связь допускает значительно более свободное толкование отношений между частями сложного предложения, чем это делают союзы. И для поэтического текста это - достоинство, преимущество ${ }^{274}$. Попробуем показать это на примере короткого стихотворения Феликса Чечика (орфография и пунктуация соблюдены):

еще не возникли возникнут вот-вот кошмары и страхи не видно конца черны от черники и руки и рот

273 Парщиков (2014, с. 133).

274 Норман (2017б, с. 354-362). 
и в белой рубахе

хоронят отца

(«Еще не возникли...») 275 .

Фрагментарность детских воспоминаний, помноженная на «тесноту стихотворного ряда» (Ю.Н. Тынянов), позволяет предположить различные логические (временные, причинно-следственные, уступительные и пр.) связи между отдельными частями стихотворения. Что имел в виду поэт в первых двух строках: «еще не возникли - но возникнут вот-вот» или «еще не возникли, хотя возникнут вот-вот»? И, далее: «кошмары и страхи, которым не видно конца» или «кошмары и страхи из-за того, что не видно конца» и т.п.? Читатель сам волен выбрать вариант, согласующийся с его языковым и жизненным опытом. Амбивалентность бессоюзной связи, оставляющая читателю некоторое пространство для домысла, фантазии, делает его в каком-то смысле «соавтором» текста. Но и внутреннее противодействие строки и предложения служит, в конечном счете, тем же общим целям.

А классический образец русской поэзии абсурда - стихотворение Даниила Хармса «Случай на железной дороге» (1926) - весь основан, можно сказать, на торжестве строки над предложением.
Как-то бабушка махнула
и тотчас же паровоз
детям подал и сказал:
пейте кашу и сундук.
Утром дети шли назад
сели дети на забор
и сказали: вороной
поработай, я не буду... ${ }^{276}$.

Строки здесь прекрасно организованы. Это двусложный размер с сильной позицией на первом слоге (хорей). А вот что касается предложения, то перед нами - очевидное (и преднамеренное!) нарушение правил синтаксической организации: почти во всех случаях «чего-то не хватает». Можно, конечно, попробовать восстановить пропущенные звенья, привести высказывания к грамматическим образцам - закрепленным в общественной памяти структурам (о чем писал В.Г. Адмони), а заодно восстановить и связи между высказываниями. Тогда мы получим примерно следующее:

Как-то бабушка махнула [рукой]

и тотчас же паровоз

детям подал [сигнал] и сказал:

Пейте [чай, ешьте] кашу и [не трогайте] сундук.

Утром дети шли назад.

Сели [они, эти] дети, на забор,

275 Чечик (2018, с. 27).

276 Хармс (1988, с. 51). 
[увидали коня] и сказали [ему:] «Вороной, поработай, я не буду [тебе мешать]...»²77.

Такой - искусственно восстановленный - текст полностью отвечает правилам грамматики, но при этом теряет всю свою «красоту неуклюжести», весь игровой эффект. Мы понимаем: ритмика, отчетливая, как в детской считалке, уже создает художественный текст, но преувеличивать возможности строки и пренебрегать предложением как единицей синтаксической организации возможно только до определенных пределов, в особых эстетических целях.

Напомним, что именно необходимостью структурировать текст, разбивать его на логико-интонационные элементы Владимир Маяковский мотивировал введение своей стихотворной техники - «лесенки». Он как бы шел в этом отношении навстречу читателю, облегчая тому понимание текста. Он писал:

Надо принять во внимание среднесть читателя, надо всяческим образом приблизить читательское восприятие именно к той форме, которую хотел дать поэтической строке ее делатель. Наша обычная пунктуация с точками, с запятыми, вопросительными и восклицательными знаками чересчур бедна и маловыразительна по сравнению с оттенками эмоций, которые сейчас усложненный человек вкладывает в поэтическое произведение.

Размер и ритм вещи значительнее пунктуации, и они подчиняют себе пунктуацию, когда она берется по старому шаблону ${ }^{278}$.

И в доказательство Маяковский приводил строки А. Толстого

Шибанов молчал. Из пронзенной ноги

Кровь алым струилася током...,

которые «все читают» как Шибанов молчал из пронзенной ноги... Строка побеждает предложение! По Маяковскому, надо было бы расположить строки так:

Шибанов молчал.

Из пронзенной ноги...

Кровь алым струилася током...

Конфликт между двумя соперничающими структурными единицами поэтического текста может высекать и искру эстетического эффекта. Обратимся опять к современным авторам. Пятистишие Юрия Казарина начинается такой строкой: $O$, Господи, не умирай... Эта строка настораживает или даже пугает читателя. Вот к чему приводит самодостаточность, относительная автономность строки в поэзии! Как это: обращение к Богу, вездесущему и всевидящему, вечному и вневременному, сопровождается просьбой: «Не умирай!»? Что - Бог оказывается, подобно человеку,

277 Норман (2012а, с. 143).

278 Маяковский (1960, с. 485). 
смертным? И человек, существо, созданное из праха и в прах уходящее, осмеливается желать Богу продлить его жизнь?

Но следующая строка все ставит на свое место и в целом стихотворение получает следующий вид:

$\mathrm{O}$, Господи, не умирай

своих животных и растений

и не вперяй без потрясений

тяжелый, нежный ад осенний

в мерцающий и мертвый рай. ${ }^{279}$

Здесь тоже, конечно, есть над чем задуматься: растения вместе с животными попадают в категорию одушевленных существ, а глагол вперять употребляется в особом значении, примерно как 'превращать' или 'вставлять'... Но главное - синтаксис всего предложения поправляет смысл первой строки. Оказывается, умирать здесь - переходный глагол, он имеет объект, а вся конструкция - каузативная! Не умирай кого-то - значит 'не позволяй кому-то умереть', 'не делай так, чтобы кто-то умер'. Очевиден философский и эстетический подтекст стихотворения, а началось-то все со строки, в синтаксическом отношении незавершенной.

То, что смысл уже воспринятой (прочитанной и понятой читателем) строки может сильно измениться в его оперативной памяти, когда на вход поступит следующая строка, подтверждает: читателю стихотворного текста «удобно» мыслить не предложениями, а строками. Но тогда - надо быть готовым к психологическим возвратам и переосмыслениям, как в следующем, уже знакомом нам случае:

Но не пленить тебя ни пирамидой

фаянсовой давно не мытой

посуды в раковине, ни палаткой сахары сладкой.

Тебе не до того. Тебе не до мельхиоровой их дербедени...

(И. Бродский. «Муха») ${ }^{280}$.

Пирамида здесь сначала воспринимается в своей отнесенности к Египту (и дальше эта ассоциация подтвердится обыгрыванием многозначного сахара), палатка тоже сначала связывается в сознании с туристическим бытом или торговым киоском - потом и этот образ заменяется другим. И, наконец, составная рифма тебе не - дребедени заставляет задуматься о значимом разрыве синтаксической единицы между соседними строками.

Самое яркое проявление борьбы строки с предложением (и наоборот) - это анжамбеман (или анжамбман, фp. enjambement), т. е. перенос небольшой части предложения, начальной или конечной, на соседнюю

279 Казарин (2009, с. 27).

280 Бродский (1992, 2, с. 135). 
строку. Соответственно, следует различать анжамбеман препозитивный (contre-rejet, когда начало предложения дается на предыдущей строке, a основная его часть переносится на следующую) и постпозитивный (rejet, когда основная часть синтаксической конструкции задана на предыдущей строке, а следующей достается ее «хвост»).

Пример первого:

Живи меня. Живи в меня. Вживи

себя в меня, как новый орган чувства, чье назначенье - различенье чуда

и растворенье радости в крови.

Живи меня, как я тебя. Живи

(В. Павлова. «Письма в соседнюю комнату») ${ }^{281}$.

Пример второго:

Несчастны все, и самые счастливые.

Какие дни отпущены тоскливые

Им, сколько тьмы, и горестей, и бед!

Упреки им свои несправедливые

Возьми назад. И разве смерти нет?

(А. Кушнер. «Несчастны все, и самые счастливые...») ${ }^{282}$.

Психологически более сильное воздействие оказывает, по-видимому, анжамбеман постпозитивный. Дело в том, что читательское восприятие направлено вперед (для привычного нам текста - слева направо, сверху вниз) и «повисающее» в конце строки начало нового предложения позволяет так или иначе прогнозировать его продолжение. Вариант же с постпозитивным анжамбеманом часто оказывается для читателя непредсказуемым и требует возврата к уже осмысленному. В этом отношении он полностью соответствует тому, что в психологии называется эффектом обманутого ожидания.

Существует уже целый ряд работ, посвященный типологии и прагматике анжамбемана ${ }^{283}$, но, не вдаваясь в детали, заметим, что сила воздействия данного приема (его «эффективность») увеличивается при некоторых условиях. В частности, эффект переноса усиливается, если между строками распределяется фразеологическое или терминологическое сочетание или если на соседней строке оказывается обязательный элемент (актант) синтаксической модели, использованной в данной строке. Ожидание читателя оказывается «особенно обманутым», если при анжамбемане служебное слово отрывается от основного, полнозначного, или же

281 Павлова (2008, с. 183$)$.

282 Кушнер (2018, с. 58).

283 Степанов (2002, с. 139-140); Матяш (2015, с. 27-29) и др. 
между строками разрывается слово как лексическая единица. Особый эффект достигается при использовании на границе строк грамматических омонимов, что ведет к двусмыслице или к переосмыслению уже воспринятой части стихотворения ${ }^{284}$.

Приведем примеры, иллюстрирующие некоторые из упомянутых ситуаций.

Дождь вчера налетел - прорвался и вдруг потек на

Губы старых балконов; бил в водосточный нос.

Я всё жду тебя, на дорогу таращу окна

Вот, и кровь в батареях стынет; и снится снос

(В. Полозкова. «Пятиэтажка») 285 .

Но простушка-душа, дожидаясь в передней, обмирает - и этого не передать никому, никогда, ни на средней, ни на ультракороткой волне

(Б. Кенжеев. «Шелкопряд, постаревшей ольхою не узнан...») ${ }^{286}$.

- Уходишь темно и приходишь темно...

«И черная ветка стучится в окно», -

додумаю за нее,

за женщину эту, сидящую в

автобусе темном, похожем, увы,

на это ее житье

(О. Хлебников. «Уходишь темно и приходишь темно...») $)^{287}$.

Нежность, нелегко

дался твой урок:

не предсмертность, - по-

смертность лучших строк

(В. Павлова. «Погаси, мой свет...») ${ }^{288}$.

Может, мясо

так лежало,

слышит «мяу», са-

мо сбежало

(В. Соснора. «Простая песенка») $)^{289}$.

284 Зубова (2017, с. 30-34).

285 Полозкова (2012, с. 83).

286 Кенжеев (2011, с. 48).

287 Хлебников (1986, с. 111).

288 Павлова (2004, с. 19).

289 Соснора (1989, с. 274). 
Большим мастером и любителем анжамбемана была, как известно, Марина Цветаева. Разрыв строки у нее нередко приходится даже на соседние строфы. Приведем в качестве примера концовку ее знаменитого стихотворения «Попытка ревности» (1924):

Как живется вам с товаром

Рыночным? Оброк - крутой?

После мраморов Каррары

Как живется вам с трухой

Гипсовой? (Из глыбы высечен

Бог - и начисто разбит!)

Как живется вам с стотысячной -

Вам, познавшему Лилит!

Рыночною новизною

Сыты ли? К волшбам остыв,

Как живется вам с земною

Женщиною, без шестых

Чувств?

Ну, за голову: счастливы?

Нет? В провале без глубин

Как живется, милый? Тяжче ли,

Так же ли, как мне с другим?290

Анжамбеман, в принципе, - относительно редкое явление, и воспринимается он именно на фоне «нормальных» случаев, когда границы строки и предложения (или хотя бы синтагмы) совпадают. Это подтверждает наш тезис, что в сознании рядового читателя метрическая и синтаксическая организация поэтического текста не только соперничают, но и коррелируют. Если же стихотворение целиком построено на приеме анжамбемана, то это снижает эффективность последнего: читатель «привыкает» к приему и оценивает его как попытку словесной игры, плетения словес, своего рода штукарство. Примеры:

В Прекрасную Овчарню, где когда-то

Ягненком спал, - в Овчарню, где ягнята

Когда-то спали, - выспались давно, -

В Прекрасную Овчарню не дано

Вернуться из отлучки. И не надо...

(А. Межиров. «Воспоминание о Флоренции») $)^{291}$.

Как боялся он пространства

Коридоров! Постоянства

290 Цветаева (1984, 1, с. 273).

291 Межиров (1989, с. 19). 
Кредиторов! Он, как дар,

В диком приступе жеманства

Принимал свой гонорар

(А. Тарковский. «Поэт») $)^{292}$.

Полно вам искать промашек

Друг у друга. Лучше делом

Заниматься. Захромавших

Исцелять. А оголтелым

Прочищать мозги. Засевших

В чащах выводить на след

Истины. А закосневших

За руку тянуть на свет

(Д. Самойлов. «Полно вам искать промашек...») $)^{293}$.

Это напоминает используемые в лингводидактике упражнения на расстановку в тексте знаков препинания (и пауз в устной речи). Так, по учебным пособиям и занимательным грамматикам кочует следующий шутливый текст (авторства Г. Граник):

Кисель там варят из резины

Там шины делают из глины

Кирпич там жгут из молока

Творог готовят из песка

Стекло там плавят из бетона

Плотины строят из картона

Обложки там из чугуна

Там варят сталь из полотна...

$$
\text { и т.д.... }
$$

Он выглядит абсурдным до тех пор, пока паузы не будут расставлены должным образом. Имеется в виду:

Кисель там варят. / Из резины

Там шины делают. / Из глины

Кирпич там жгут. / Из молока

Творог готовят... и т.д.

Следует признать, что несовпадение метрического и синтаксического членения текста, т.е. «борьба» строки и предложения, в принципе, осложняет деятельность реципиента. Однако данный прием вознаграждает читателя и слушателя тем, что порождает дополнительный эстетический эффект. «Единство законченной незаконченности» (С.В. Калачева), как и любое парадоксальное явление, придает произведению искусства третье (или четвертое) измерение. Не случайно в XX веке этот прием так активно использовался крупнейшими русскими поэтами -

292 Тарковский (1982, с. 151).

293 Самойлов (1992, с. 31). 
кроме М. Цветаевой, также Б. Пастернаком, А. Тарковским, И. Бродским и др.; продолжается эта традиция и в XXI столетии ${ }^{294}$.

В явлении анжамбемана фокусируется и более общая проблема: соотношение устного текста (с его ритмической организацией, в том числе паузами) и письменного (с его пробелами и знаками препинания). Стихотворная строка ведь - не только ритмическая, слуховая единица, но и зрительная, графическая. Глаз привыкает к тексту, представленному вертикальным «столбиком», и хочет, чтобы его правая граница была столь же определенной, как и левая (начало строк). Заданная (т.е. вынужденная для поэзии) краткость предложения оборачивается разным результатом применительно к немногосложным и многосложным размерам. Наконец, распределение синтаксической единицы между строками способствует и созданию общего настроя, эмоциональной атмосферы стихотворения ${ }^{295}$.

Предложение и строка как две основные единицы структурной организации конкурируют в стихотворном тексте (обычно с преимуществом второй из них), но в общем и целом взаимодействуют и дополняют друг друга.

294 Степанов (2011); Авчиева (2015).

295 Калачева (1977, с. 52-56). 


\section{Глава 5. Особенности глагольного управления в поэтическом тексте (и падежные вариации в стихотворении Ю. Левитанского)}

Управление - один из способов организации текста. В русской грамматике оно рассматривается как один из трех основных типов синтаксических связей между словами (согласование, управление, примыкание). Суть этой связи хорошо отражается в распространенной сегодня предикатно-аргументной модели предложения: вершина этой структуры, предикат (в наиболее частом случае - глагол), открывает некоторое количество и качество зависимых от него позиций. Говоря более традиционным языком, лексическая семантика глагола диктует выбор грамматической формы зависимых от него слов ${ }^{296}$. В рамках академической грамматики строгое определение этому виду связи было дано М.В. Пановым:

«Если в словосочетании АБ основа слова А вызывает определенную флексию у слова Б, то налицо связь управления <...> Если лексема А в сочетании с лексемой Б может использовать все свои флексии, а лексема Б - не все, то А - главный член, а Б - зависимый <...> В сочетании пишет письмо глагол использует все свои флексии, а существительное только одну; оно зависимо» 297.

«Левый» конец этой связи (лексическое значение глагола) - чрезвычайно важная сторона рассматриваемого феномена. Практика показывает, что глаголы, сходные по своему лексическому значению, обнаруживают склонность к общему для них типу валентности. Поэтому можно говорить об управлении, свойственном целой лексико-семантической группе глаголов. Скажем, глаголы со значением «заинтересованного отношения» требуют постановки зависимого слова в творительном падеже - увлекаться, интересоваться, соблазняться, загораться и др., а глаголы «проникновения внутрь объекта» - зависимого слова в винительном падеже с предлогом в: всматриваться, вглядываться, вслушиваться, вдумываться, вчитываться и т.д. (не случайна здесь и исторически обусловленная корреляция префикса и предлога). Перед нами путь к классификации глаголов, разбиению их на семантические группы, подтверждаемый формально-синтаксическими признаками ${ }^{298}$.

На ту же, лексико-семантическую, версию управления («лексическое значение находит себе выражение в формальных признаках зависимого слова») работают случаи, когда, казалось бы, у одного и того же глагола могут быть зависимые существительные в разных падежных формах.

296 Кобозева (200о, с. 219-223).

297 Панов (1966, с.103).

298 Бабенко (ред.) (2002). 
Объясняется это очень просто: разное управление - признак разных глаголов, слов-омонимов.

Это очевидно в случаях типа везти + ВП (везти мальчика) и везти + ДП (безл.: везет мальчику), нести + ВП (нести рыбу) и нести + ТП (безл.: несет рыбой) - перед нами разные глаголы. Менее очевиден этот вывод в случаях вроде бояться чего (Девочка боится темноты) и бояться за

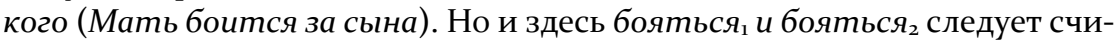
тать разными глаголами: об этом говорят не только зависимые от них формы, но и особенности лексической дистрибуции. И если словари все же толкуют их в рамках одной словарной статьи ${ }^{299}$, то это - проявление лексикографической инерции (или даже, как выражался Л.В. Щерба, «типографской точки зрения» ${ }^{300}$ ). Точно так же разными словами следовало бы считать жертвовать что и жертвовать чем - это разные жертвовать, страдать из-за чего и страдать по чему - это разные страдать, считать что и считать кого чем - это разные считать и т.п.

По той же логике вещей, если глагол со временем меняет свойственный ему тип управления, то это должно свидетельствовать об изменении его лексического значения. Такие случаи многократно анализировались в научной литературе. Так, еще Ф.И. Буслаев, рассмотрев множество примеров исторического изменения управляемых форм, видел одну из причин в «расширении круга понятий»: «Один и тот же глагол, переходя от одного значения к другому, получает управление тех синонимов, с которыми приводится в связь» ${ }^{\circ 0}$. Скажем, для глагола надеяться в языке XIX века было характерно управление беспредложным родительным падежом имени: надеяться милосердия, надеяться участия, надеяться письма и т.п. Значение этого глагола было близко к значениям слов желать, ждать, ожидать, также управляющих родительным без предлога. Постепенно эта зависимая форма (уже у Пушкина) вытесняется формой на + ВП: появляется конструкция надеяться на участие и т.п. Дело, повидимому, в сближении семантики данного глагола с глаголами более «уверенной» семантики, типа полагаться, возлагать надежды, рассчитывать, делать ставку и т.п.

Любопытно, кстати, что из длинного списка глаголов с вариативным управлением, который приводит Ф. И. Буслаев в своей «Исторической грамматике» как «наиболее затрудняющих на практике», сегодня абсолютное большинство уже вышли из этого состояния, выбрали одну из форм, а другую оставили истории языка. Но язык - живая материя, и на место этих колебаний приходят другие. В целом же «в процессе всеобщего развития словесных значений, их интеграции и дифференциации

299 Кузнецов (ред.) (1998).

300 Щерба (1974, с. 290)

301 Буслаев (1959, с. 504). 
непрерывно складываются одни и распадаются другие лексико-семантические классы. Этому соответствует постоянная интеграция и дифференциация синтаксических признаков»302.

Способность глагола выстраивать вокруг себя набор подчиненных форм не только имеет в своей основе и по-своему реализует лексическое значение данной части речи, но в значительной степени и прогнозирует его, глагола, развитие. Об этой, динамической, стороне валентности, обращенной в будущее, писал А.Ф. Лосев:

Она не просто есть или существует в слове, но она является его смысловой мощью, ее разносторонней и даже трудно исчислимой семантической потенцией. Валентность слова, действительно, можно сказать, есть его основное значение. Но это не просто основное значение, а еще и заложенная в нем потенция весьма разнообразных значений ${ }^{303}$.

В то же время в языке можно найти факты, которые подвергают сомнению высказанный выше тезис о тесной связи лексической семантики управляющего слова с формой зависимого слова. В частности, некоторое противоречие сказанному мы находим в том, что глаголы, традиционно считающиеся синонимами, могут различаются своим типом управления. Скажем, русское стесняться обычно имеет при себе зависимую форму в родительном падеже: Он стесняется соседей, а равнозначный ему смущаться - непереходный: Он смущается. Глагол советовать требует зависимого имени в дательном падеже: советовать студенту (как помогать, содействовать, сочувствовать и т.п.), а близкий ему по значению консультировать подразумевает зависимый винительный падеж: консультировать студента (как обучать, поддерживать, опекать и т.д.). Баловать диктует выбор управляемого имени в винительном падеже баловать ребенка, а потакать с близким значением сочетается с дательным: потакать ребенку... Как это объяснить?

Объяснить это можно двумя способами. Первый - через эволюционный характер языка: его система постоянно находится в состоянии динамического равновесия, оптимизируя структуру внутренних классов и их отношения. Это - издержки работающего языкового механизма. Теми же причинами объясняются имеющие место случаи варьирования управления без изменения смысла: рассказывать про что / рассказывать о чем, ждать чего / ждать что, писать кому / писать к кому, не заметить ошибку / не заметить ошибки и т.п. (хотя и тут есть закономерности статистического распределения)304. Об этом - эволюционном - объяснении уже шла речь выше.

302 Норман $(1975$, с. 128).

303 Лосев (1981, с. 408).

304 Граудина, Ицкович, Катлинская (1976, с. 33-6о). 
Второй же способ объяснить расхождение зависимых форм при синонимичных глаголах - попытаться вскрыть, эксплицировать тонкие различия в их значениях, обусловленные особенностями отражаемой ситуации: ее фреймовой структурой, личностью говорящего и слушающего и т.д. Это требует дополнительного разъяснения. В качестве слотов таких фреймов могут выступать «малозначимые» детали: величина объекта или его расчлененность, сознательность (активность) действия, наличие инструмента или технологии, протяженность во времени, отработанность (узуальность) в виде практического навыка, исторический контекст и др. ${ }^{305}$

Например, глаголы повиноваться и подчиняться считаются синонимами (с оговоркой: первый из них чуть «выше» по стилю и употребляется почти в два раза реже). При этом их формальный синтаксический признак - един: это управление именем в дательном падеже. Толковый словарь трактует повиноваться через подчиняться: «1. Беспрекословно слушаться кого-л., подчиняться кому-, чему-л. П. приказу, распоряжению... 2. Послушно действовать, слушаться кого-л. (об управляемых механизмах или частях тела). Машина плохо повиновалась водителю... Отекшая рука не повиновалась...» ${ }^{306}$. Статья о втором глаголе - подчиняться отсылает нас к глаголу совершенного вида подчиниться: «1. Оказаться в психической или экономической зависимости от кого-, чего-л., от чьей-л. воли, власти; повиноваться кому-л. П. силе оружия. П. чужому влиянию...» ${ }^{307}$. И тут в правой части словарной статьи мы находим повиноваться. Симптоматично: повиноваться и подчиняться толкуются в словаре друг через друга - это наглядное доказательство их синонимии!

Однако в речи возможна ситуация, когда данные глаголы противопоставляются друг другу. Достаточно найти между ними тонкое семантическое расхождение, вставить в этот зазор «нож» особой ситуации и повернуть его - тогда глаголы превращаются в контекстуальные антонимы. В политологии есть понятие «оружие слабых»: когда публичный протест населения невозможен, то внутреннее несогласие становится единственной доступной формой сопротивления. Символом такого «диссидентства» выбрана пословица испанских крестьян: Я подчиняюсь, но не повинуюсь. В семантике повиноваться актуализируется сема 'беспрекословно' (она фигурирует и в словарном определении), что подразумевает и внутреннее, идейное подчинение. В то же время 'я только подчиняюсь', я не повинуюсь так, как «механизм или часть тела» - носитель языка может почувствовать и подчеркнуть и это вторичное значение глагола.

Любопытно и лексическое заполнение позиции аргумента. Для этого обратимся к Генеральному интернет-корпусу русского языка (ГИКРЯ),

305 Норман (2008, с. 296-297); Норман (2011, с. 243-248).

306 Кузнецов (ред.) $(1998$, с. 852$)$.

307 Кузнецов (ред.) (1998, с. 886). 
отражающему материал блогов, соцсетей, литературных журналов и новостных сайтов. Он позволяет задать грамматические и лексические слоты для интересующих нас конструкций. По данным ГИКРЯ, зафиксированным для подчиняться, безусловный лидер среди партнеров этого глагола - существительное закон в дательном падеже. Подчиняться закону - примерно 1/6 часть всех словосочетаний с этим глаголом. Затем следуют приказ, правило, воля, требование, команда, решение, логика, мужччна... Для повиноваться начало частотного списка похоже: закон, инстинкт, приказ, воля..., но уже в первом десятке появляется аллах, а в начале второго - бог...308. Можно утверждать, что для подчиняться важнее рациональная составляющая поведения, в то время как в употребление повиноваться вмешиваются сверхъестественные и трудно вербализуемые мотивы. Эти различия, несомненно, чрезвычайно тонки, однако если «испанские крестьяне» смогли их почувствовать, значит, они - различия - существуют!

Такому же детальному анализу можно подвергнуть любые упомянутые выше глаголы, в том числе баловать (кого) и потакать (кому). Первому из них словарь приписывает такое толкование: «Потворствовать капризам, прихотям, относиться к кому-л. с особой заботой, вниманием, лаской. Б. любимое детище. Б. своих учеников...» ${ }^{309}$. В статье Потакать читаем: =Потворствовать. П. капризам, прихотям, слабостям. Обращаемся к глаголу потворствовать. Его значение в словаре определяется так: «Снисходительно относиться к кому-, чему-л. (обычно плохому, предосудительному); попустительствовать. П. капризам ребенка. П. чьейнибудь лени, разгильдяйству...»¹0. Хотя, как мы видим, и баловать, и потакать толкуются через потворствовать (классическая ситуация синонимии с tertium comparationis), даже из данных определений можно вывести некоторые существенные семантические различия. В потворствовать сильнее негативная оценка действий (упоминается сема 'плохое, предосудительное'). В толковании глагола баловать упоминается явно позитивное отношение: «забота, внимание, ласка». Далее, в качестве объекта баловать фигурирует живое существо, чаще всего ребенок. Для потворствовать объектом может быть и взрослый человек, и его свойство: лень, разгильдяйство («баловать лень, разгильдяйство» сказать нельзя). И дело даже не в том, как мы квалифицируем этот ближайший к глаголу аргумент: как «объект» или как «адресат». Важнее то, на какие другие глаголы проецируется значение данного глагола, с какими из них он состоит в наиболее близких отношениях. Баловать синтаксически «проецируется» на опекать, любить, нежить, ласкать, гладить, покрывать,

308 ГИКРЯ (о8/02/2019).

309 Кузнецов (ред.) (1998, с. 57).

310 Кузнецов (ред.) (1998, с. 940). 
защищать и т.п.), а потакать - на глаголы потворствовать, попустительствовать, покровительствовать, угождать, помогать, благоприятствовать и т.д. Этот семантический «шлейф», тянущийся за словом в сознании, и позволяет говорящему в большинстве случаев безошибочно выбрать нужную лексему.

Наконец, стоит сравнить и употребление глаголов в тексте. Национальный корпус русского языка фиксирует для баловать 300 документов (361 вхождение); типичные партнеры слова - сына, ребенка, себя. Для потакать обнаружено 176 документов (195 вхождений); среди его стандартных партнеров - существительные с отвлеченным значением: потакать капризам, вкусам, желаниям. ${ }^{311}$ То, что на первый взгляд казалось синонимами, таковым и осталось, но только на первый взгляд. Синтаксические признаки «работают» на семантическую характеристику слова.

Особую значимость приобретают эти синтаксические характеристики, когда они сопровождаются статистическими данными. Мы в соавторстве с М.Ю. Мухиным попытались с когнитивистских позиций исследовать значение и поведение в речи некоторых русских глаголов с близкой семантикой. В частности, анализу подверглись глаголы добавлять (что) и дополнять (чем), значения которых «различаются главным образом своим синтаксическим компонентом: расстановкой участников ситуации и, соответственно, валентностями, которые должны быть в предложении открыты»312. Выяснилось, что тонкие различия в семантике этих глаголов подтверждаются возможностью подстановки во фразу косвенного объекта («третьего актанта»). Доля дополнять (что чем) в общем массиве фактов составила 27\%, в то время как добавить (что к чему) - лишь 1\%.

В той же работе анализировались семантические расхождения между русскими глаголами врать и обманывать. Выяснилось, что для обманывать в 44,4\% словоупотреблений присутствует объект (кого), а у врать наличие второго актанта (кому) зафиксировано только в 1\% случаев ${ }^{313}$. Получается, врать и обманывать различаются не столько «силой лжи», сколько структурой обозначаемой ситуации!

Итак, правомерна точка зрения на глагольное управление как на способ «шифровки» лексического значения, придачи ему своего рода формального индекса. Но добавим, что характер управления позволяет не только квалифицировать или уточнить значение глагола, отнести его к той или иной лексико-семантической группе, но и ввести ограничения на лексическую семантику «правого» компонента (аргумента). Через синтаксическую норму проявляются законы лексической комбинаторики (сочетаемости), и управление - связь, действующая в обе стороны.

311 НКРЯ (22/08/2019).

312 Норман, Мухин (2016, с.2).

313 Норман, Мухин (2016, с. 7-8). 
Скажем, винительный падеж с предлогом по в значении цели движения подразумевает употребление существительного со значением природного объекта: пойти по грибы или по ягоды, поехать по дрова, отправиться по воду и т.п.:

Едем с дедушкой по сено,

Лошадь дышит тяжело...

(Ю. Казарин. «Едем с дедушкой по сено...») $)^{314}$.

Когда-то норма сочетаемости в этом отношении была более широкой. Старая русская пословица гласит: Пошел по шерсть, а вернулся стриженым. В XIX веке можно было сказать и пойти по соседа, и побежать по подмогу315. Но для современного литературного языка подобные обороты выглядят архаичными, ср.: Она читает запоем, и всё - дребедень, ничего не запоминая и выпуская длинные описания. Ходит по книги в русскую библиотеку, сидит там у стола и долго выбирает... (В. Набоков. «Отчаяние») ${ }^{316}$. Возможно усмотреть в такой форме и стилизацию под диалектную речь: ...Тамарочке Александр нашел на том же рынке большие мужские сапоги на меху! Стояли брошенные! Пошел по сапоги для себя, а принес для нее...(Л. Петрушевская. «Ребенок Тамары») $)^{317}$.

А форма винительного падежа с предлогом в, обозначающая при глаголах развития «квалификацию генетического подобия» ${ }^{318}$, тоже не безразлична к своему лексическому заполнению. Можно сказать пойти в отца, выйти лицом в мать, выдаться в родню и т.п. - но это все названия старших родственников. Сказать Он вышел лицом в соседа можно только в виде грубоватой шутки. Управление - способ соотнесения двух лексических группировок, глагольной и именной. Иначе говоря, это не только конвенциональная связь между главным и зависимым словом в высказывании, но и способ организации лексики, семантического упорядочения как глагольных, так и именных классов.

У концептуалиста Льва Рубинштейна есть произведение «Это всё» $(1975)^{319}$, которое больше похоже на страницу учебного пособия по синтаксису русского языка. Одно верно: перечисленные здесь предикаты (главным образом глагольные) нуждаются в обязательных распространителях. Это всё схемы разных типов управления. Приведем текст целиком.

314 Казарин (1991, с. 133).

315 Норман (2016, с. 114).

316 Набоков (1990, с. 346).

317 Петрушевская (2010, с. 68).

318 Золотова (1988, с. 167).

319 Рубинштейн (2013). 
1.

ЭТО ВСЁ Значит

(что?)

- выражает

(что?)

- объясняется

(чем?)

2.

ЭТО ВСЁ строится

(на чем?)

- связано

(с чем?)

- апеллирует

(к чему?)

3.

ЭТО ВСЁ порождено

(чем?)

- относится

(к чему?)

- усугубляется

(чем?)

4.

ЭТО ВСЁ напоминает

(что?)

- взывает

(к чему?)

- исходит

(из чего?)

5.

ЭТО ВСЁ уходит

(куда?)

- дает

(что?)

- заслуживает

(чего?)

6.

ЭТО ВСЁ находится

(где?)

- приводит

(к чему?)

- содержит

(что?)

7.

ЭТО ВСЁ уступает

(чему?)

- совместимо

(с чем?) 
- несовместимо

(с чем?)

8.

ЭТО ВСЁ

При всей демонстративной «нехудожественности» этого произведения понятно, на чем основан замысел автора: показать значимость синтаксических шаблонов, или моделей, которые заложены в сознании говорящего и реализуются в процессе текстопорождения. Обратимся теперь к особенностям реализации связи управления в полноценных поэтических текстах.

Если соглашаться с тем, что грамматическое управление - не только вид синтаксической связи между словами, но и способ организации мысли, реализующейся в тексте, то нужно при этом, конечно, учитывать особые дискурсивные условия. Дело в том, что в поэзии существует масса иных средств организации текста - такие как ритмика, строка, рифма, многообразное семантическое согласование и т.п. Встречаются даже «аграмматические» стихотворения, смысл и эмоциональное воздействие которых базируется на ритме и совокупности ассоциаций, протягивающихся между представленными здесь лексемами (об этом уже шла речь). Получается, что в поэзии необходимость в синтаксическом управлении меньше, чем в «не-поэзии», потому что здесь слова связываются по иным правилам. И, соответственно, степень свободы поэта в использовании грамматических правил - бо́льшая, чем у обычного говорящего, в том числе даже большая, чем в спонтанной разговорной речи:

Поэтическая речь заходит гораздо дальше разговорной речи в нарушении симметрии между формой и функцией. Она дополняет систему общеязыковых функций своими специфическими функциями, а систему общеязыковых средств выражения своими специфическими средствами ${ }^{320}$.

Вступая в ассоциативные связи с представителями иных лексико-семантических групп, глаголы меняют свой тип синтаксического поведения. В том числе непереходные глаголы могут окказионально приобрести переходность. Приведем несколько примеров.

Пусть жизнью связи портятся,

Пусть гордость ум вредит.

Но мы умрем со спертостью

Тех розысков в груди

(Б. Пастернак. «Образец») $)^{321}$.

Сперва работать начал он

Классический аттракцион:

320 Ковтунова (1986, с. 196).

321 Пастернак (1989, 1, с. 127). 
Зигзагами по вертикали

На мотоцикле по стене...

(А. Межиров. «Баллада о цирке») 322 .

Какой ты тихий, примеряя шапки!

Шаткий воздух в зеркале наклоня.

Ты думаешь, у меня есть шансы?

Ты, малыш, выздоровеешь меня

(А. Парщиков. «Матвею») ${ }^{323}$.

Я маленькая балеринка

Живущая на склоне лет

Моя цветная пелеринка

Повылиняла весь свой цвет

(Д. Пригов. «Я маленькая балеринка...») $)^{324 .}$

Вредить ум (по аналогии с портить), работать аттракцион (а также работать номер, распространенное в профессиональном сленге артистов, - как «выполнять»), выздороветь кого-то (в смысле «вылечить»), повылинять цвет (в смысле «потерять») и т.п. - все эти факты, выглядящие неуклюже в прозе, теряют свою «особость» в поэтическом окружении. Аналогичные примеры «аномальной переходности» в новейшей поэзии (грешу слова́, молчу поцелуй, машет круги, плачут маму и т.п.) исследовала Л.В. Зубова325. Она же продемонстрировала окказиональное развитие векторной валентности при экзистенциальных глаголах, глаголах неконтролируемого действия, статичного положения в пространстве и т.п. (Куда случилось с миром? Куда она лежит; куда умереть и т.п.) ${ }^{326}$.

Окказиональная «векторная валентность», или направленность на объект, возможна в поэзии и при других глаголах, ср. две цитаты из Андрея Вознесенского:

Сирень прощается, сирень - как лыжница,

Сирень, как пудель, мне в щеки лижется!

(А. Вознесенский. «Сирень "Москва-Варшава"») $)^{32}$.

Запомни этот мир, пока ты можешь помнить, а через тыщу лет и более того,

322 Межиров (1989, с. 184).

323 Парщиков (2014, с. 216).

324 Пригов (1997, с. 110).

325 Зубова (2009, с. 45-49).

326 Зубова (2009, с. 40-43).

327 Вознесенский (1975, с.447). 
Ты вскрикнешь,

и в Тебя царапнется шиповник...

И - больше ничего

(А. Вознесенский. «Романс») $)^{328}$.

Глаголы лизаться и царапаться в принципе не подразумевают конкретного объекта, они обозначают свойства субъекта ${ }^{29}$ (кошка лижется, куст царапается). А сочетания лизаться (кому-то) в щеки и царапнуться в тебя возникают, очевидно, по аналогии с уткнуться, воткнуться, вонзиться во что-либо.

Поведение словоформы в поэтическом тексте следует рассматривать в комплексе с иными используемыми средствами - лексическими, ритмическими, графическими и др. Покажем это на примере известного стихотворения Юрия Левитанского «Каждый выбирает для себя». В этом произведении речь идет о свободе личного выбора. Человек волен выбирать себе по жизни партнера, религию, оружие... Мысль не новая, но очень важная своим результатом: не следует пенять на обстоятельства; в конце концов, человек сам формирует свою судьбу. Стихотворение было положено на музыку Сергеем Никитиным и с успехом исполнялось в разной аудитории, что по-своему подтверждает и важность затронутой темы, и общедоступность ее разработки. Структура стиха безупречна. Размер - пятистопный хорей; рифмовка не просто опоясывающая, но первая и последняя строка в каждой строфе совпадают, что создает эффект закольцованности. Приведем этот текст целиком.

Каждый выбирает для себя женщину, религию, дорогу. Дьяволу служить или пророку каждый выбирает для себя.

Каждый выбирает по себе слово для любви и для молитвы. Шпагу для дуэли, меч для битвы каждый выбирает по себе.

Каждый выбирает по себе. Щит и латы. Посох и заплаты. Мера окончательной расплаты. Каждый выбирает по себе.

Каждый выбирает для себя. Выбираю тоже - как умею.

328 Вознесенский (1976, с. 91).

329 Апресян [и др.] (2010, с. 290-291). 
Ни к кому претензий не имею.

Каждый выбирает для себяз30.

Обратим внимание на намеренные лексические повторы в стихотворении. И характерно, что для обозначения индивидуального характера свободы выбора автор использует две местоименные формы с предлогами: для себя и по себе. В начальной и заключительной строфах говорится: выбирает для себя, во 2-й и 3-й - выбирает по себе.

Может быть, благодаря песенному исполнению, некоторые строки стихотворения стали крылатыми, вошли в широкий обиход, попали даже в массовую литературу. Для героев следующего фрагмента романа Т. Устиновой «Хроника гнусных времен» они выступают как своеобразный пароль показатель интеллигентности, начитанности, жизненного кредо:

Он был совершенно уверен, что на пляже она ничего вокруг не видела, кроме своего Аполлона и грудастой блондинки.

- Каждый выбирает по себе... - Глядя на дым от своей сигареты, он любезно перечислил: - Женщину, религию, дорогу.

- Дьяволу служить или пророку, знаю, знаю!.. Только при чем здесь это? Вы не можете с одного взгляда установить, правильно я выбрала или неправильно! - перебила она нетерпеливо, и он искренне изумился, впервые за этот вечер. А может, даже за неделю. Или за год.

Мало кто помнил или знал эти стихи. Почти никто. «Поколение Пепси» никаких таких стихов знать не могло.

- Ну вот, - сказал он удивленно, - вы, оказывается, даже книжки читаете ${ }^{331}$.

Строки из стихотворения Юрия Левитанского служат для участников диалога не просто знаком их принадлежности к одной эпохе, но - пропуском во внутренний мир собеседника, сигналом к возможному дальнейшему сближению. Пароль узнан и принят - и далее можно делать очередной шаг ${ }^{332}$.

Любопытно, что в оригинальном тексте, в начальной строфе стихотворения, поэт пишет: каждый выбирает для себя. А персонаж упомянутого романа Устиновой, цитируя произведение по памяти, говорит: каждый выбирает по себе. Так выбирать для себя или выбирать по себе? И вообще, есть ли разница в значениях этих выражений? В стихотворении они чередуются без особой логики, и создается впечатление, что данные конструкции синонимичны.

Первое, что необходимо для ответа на поставленный вопрос, - это соотнести эти конструкции с их грамматическим фоном: выяснить, какие функции в русском языке выполняют предложно-падежные формы для + РП и по + ДП.

330 Левитанский (1982, с. 322 ).

331 Устинова $(2007$, с. 9).

332 Норман (2017б, с. 114). 
Обратимся к «Синтаксическому словарю» Г.А. Золотовой. Интересующая нас словоформа для + РП выполняет функцию дестинатива - синтаксемы, обозначающей «лицо или предмет, для которого предназначается какой-л. предмет или действие», с примерами типа пою для тебя, сделаю для людей, творишь для немногих 333 . Характерно, что статус данной формы - свободная синтаксема (т.е. она может употребляться и самостоятельно, в качестве заголовков или распространителей).

Словоформа по + ДП выполняет функцию коррелятива - «компонента со значением оценки соответствия / несоответствия», с примерами занятие по силам, пришелся по вкусу, не по себе дерево не руби и т.п.334 Статус этой словоформы - обусловленная синтаксема (т.е. ее употребление ограничено структурой предложения).

НКРЯ показывает приблизительно одинаковую частоту употребления словоформ для себя (7040 документов, 17295 вхождений) и по себе (соответственно 7371 и 18296)335. Однако если сочетаемость первой формы довольно свободная (жить для себя, дебютный для себя, неожиданный для себя и т.п.), то форма по + ДП в абсолютном большинстве случаев встречается в комбинациях сам по себе, сама по себе, само по себе, сами по себе - т.е. это фразеологизованные сочетания. А как таковая, в отрыве от сам, форма по себе довольно редкая, ее употребительность ни в какое сравнение с для себя не идет.

Семантические различия между словоформами сказываются и на выборе лексического партнера для глагола. Мы легко скажем: выбирать для себя место, время, книгу, страховку, одежду, роль, цели... В сочетании с выбирать по себе круг объектов будет более узкий: дело, работу, занятие, жену, коня...

Дело в том, что семантика предназначения, свойственная первой из форм (для + РП), связывается с проспекцией, с будущими действиями: книги мне нужны для работы значит: 'книги я использую (и буду использовать) при работе'; одежда для Пети - 'одежда, которую будет носить Петя', ищу квартиру для себя - 'ищу квартиру, в которой я собираюсь жить' и т.п.

Конструкция же, состоящая из предлога по и дательного падежа, обозначает соответствие некоторым исходным (уже сложившимся) данным или обстоятельствам. По себе тоже может обозначать свободу выбора, но только в плане ретроспекции, это взгляд, направленный к исходной точке: Ищи занятие по себе (по своим силам, интересам и т.п.). Ср. также: костюм по росту, это ему по вкусу; я это по себе знаю, поездка мне не по

333 Золотова (1988, с. 40-41).

334 Золотова (1988, с. 148-149).

335 НКРЯ (21/05/2019). 
карману, выбирай одежду по погоде и т.п. По Сеньке и шапка - это не значит «Сенька собирается купить себе подходящую шапку», а значит: «Каков Сенька (точка отсчета), такова и его шапка».

Можно увидеть в интересующих нас фактах и различный модус. Bыбирать по себе - значит 'по своим возможностям'. А выбирать для себя 'в соответствии со своими желаниями'! Различная ориентация во времени интуитивно предполагает разную модальность...

Как видим, за внешне синонимичными конструкциями может скрываться различие в довольно тонких семантических нюансах. Причем заметим: ни метрические особенности стихотворения, ни мужская рифма в конце строк не требует наблюдаемого чередования двух предложно-падежных форм! Грубо говоря, везде могло бы быть одно и тоже - или для себя, или по себе! Однако Левитанский совершенно отчетливо выбирает в 1-м и 4-м катренах для се6я, а во 2-м и в 3-м - по себе. Как это объяснить?

Возможно, поэт, чередуя в своем стихотворении эти формы, - осознанно или нет - хочет смазать, смикшировать противопоставление прошлого (исходной точки, имеющегося опыта, физических или психических возможностей и т.п.) и будущего (планируемой цели, стремлений, замыслов)? Естественным оправданием такой позиции служило бы то, что в сознании эти категории недостаточно разграничены, проспекция основывается на ретроспекции, а причина («почему») нередко смешивается с целью («зачем»).

Добавим, что и в других произведениях Юрия Левитанского можно найти со- и противопоставления грамматических форм, несущие концептуальное значение. Скажем, часто сопоставляется прошлое и настоящее («Белый снег», «В Оружейной палате», «Воспоминанье о скрипке») или настоящее и будущее («Кто-нибудь утром проснется и ахнет...», «Человек, строящий воздушные замки»). Антитеза «прошлое - настоящее», так же как своего рода путешествие во времени, обогащает философскую подкладку лирики. Если поэт позволяет себе сложную игру со временем, то, возможно, он сознательно идет и на смешение проспекции и ретроспекции, причины и цели, возможности и желания? Мы исходим из той общей пресуппозиции, что поэт не просто использует язык: это, можно сказать, и язык в каком-то смысле использует поэта, выражая через него сформировавшийся коллективный опыт. Соответственно выбор той или иной формы должен быть мотивирован какими-то когнитивными мотивами.

Для того, чтобы проверить предположение, касающееся варьирования выражений выбирать для себя и выбирать по себе, необходимо исследовать общий фон, дискурс поэтики Ю. Левитанского, найти аналогичные случаи лексических повторов и грамматического варьирования в его стихах. Нетрудно убедиться, что для творчества данного поэта лек- 
сико-грамматические повторы вообще очень характерны. Они могут выступать в виде синтаксического параллелизма соседних строк или лексических итераций. Как писал Роман Якобсон в своей статье о синтаксическом параллелизме, повторы вообще - свойство поэзии:

...Существо поэтической техники состоит в периодических возвратах, и это проявляется на каждом уровне языка. Фонемы и последовательности фонем, морфологические, лексические, синтаксические и фразеологические единицы, оказываясь в метрически или строфически аналогичных позициях, неизбежно ставят в нашем сознании или подсознании вопросы, а именно: являются ли взаимоподобными, в каких отношениях и в какой степени, эти сущности, находящиеся в аналогичных позициях $33^{36}$.

Любопытно, что у Левитанского лексические и синтаксические повторы регулярно сопровождаются частичными изменениями - либо заменой отдельной лексемы, либо варьированием порядка слов. Читателю предлагается совместить психологическое привыкание с эффектом обновления, по принципу: «То же, да не то же»! Примеры такого варьирования многочисленны и многообразны:

Таинство света и тени.

Стрелы, круги и квадраты.

Ранние наши потери,

Поздние наши утраты

(«Время, бесстрашный художник...»)337.

Была безоблачной прелюдия.

Сперва трубы гремела медь.

Потом пошли греметь орудия,

пошли орудия греметь

(«Сон о рояле» $)^{338}$.

И можно себе представить смиренный лик, и можно себе представить огромный рост, но он уходит, так же прост и велик, как был за миг перед этим велик и прост

(«Иронический человек»)339.

Только полночь опустится, как догадка о том, что уже не отпустится ни сейчас, ни потом, что со счета не сбросится

336 Якобсон (1987, с. 99).

337 Левитанский (1982, с. 163).

338 Левитанский (1982, с. 197).

339 Левитанский (1982, с. 171). 
ни потом, ни сейчас

и что с нас еще спросится,

еще спросится с нас

(«Светлый праздник бездомности...») ${ }^{340}$.

Мне на палубе слышно,

как плещет внизу Витим,

как ревет Витим,

в двух шагах почти невидим.

Я щекою небритой

ощущаю мешок вещевой,

мой дорожный мешок,

перемытый водой дождевой

$(« \text { Не брести мне сушею...») })^{341}$.

Нередко лексико-грамматические повторы доминируют в рамках одного стихотворения. В таком случае они становятся текстообразующим приемом: на них держится вся поэтическая архитектоника. Сравним два примера:

Вдали полыхнула зарница.

Качнулась за окнами мгла.

Менялась погода - смениться

погода никак не могла...

Там, памятью лета томима, томима всей памятью лет, последняя шла пантомима, последний в сезоне балет...

А дальше из сумерек дома, из комнатной тьмы выплывал рисунок лица молодого, лица молодого овал...

(«Вдали полыхнула зарница...») $)^{342}$.

Всего и надо, что вглядеться, - боже мой,

Всего и дела, что внимательно вглядеться...

Всего и надо, что вчитаться, - боже мой,

Всего и дела, что помедлить над строкою...

Каких сокровищ под ногами не заметил,

Каких созвездий в небесах не разглядел!

(«Всего и надо, что вглядеться, - боже мой...») ${ }^{343}$.

340 Левитанский (1982, с. 260).

341 Левитанский (1959).

342 Левитанский (1982, с. 265).

343 Левитанский (1982, с. 252). 
На постоянных повторах и рефренах строится и, пожалуй, самое известное стихотворение Ю. Левитанского, получившее общенародную известность благодаря кинофильму «Москва слезам не верит» (где оно звучит в виде песни):

- Что происходит на свете? - А просто зима.

- Просто зима, полагаете вы? - Полагаю...

- Что же за всем этим будет? - А будет январь.

- Будет январь, вы считаете? - Да, я считаю... 344 .

Имитация обыденного диалога, тематически направленного из настоящего в будущее, вполне естественно включает в себя повторяющиеся (воспроизводимые собеседником) фрагменты. О роли таких «скреп» в разговорной речи подробно писала в свое время Н.Ю. Шведова 345 .

Судя по приведенным контекстам (количество которых можно было бы легко увеличить), поэт любит игру со словами; он ценит возможность синонимических переодеваний и рокировок, перевертышей, словесной чехарды. Использование приема кинематографического монтажа, так же как его склонность к синтаксическим и лексическим повторам отмечалась уже давно, еще при жизни поэта ${ }^{346}$. Сочетание философской глубины и естественно-разговорного начала дает тот эффект «изощренной и простодушной поэтики» 347 , который также отмечался критиками и литературоведами. Лексико-синтаксические повторы роднят стихи Левитанского с рефренами песенной лирики. И это ритмико-мелодическое, песенное начало закономерно отразилось в том, что на слова Левитанского написано множество песен (в том числе и известные «Диалог у новогодней елки», «Всего и надо, что вглядеться...», «Иронический человек», «Вдали полыхнула зарница...» и т.д. - все они стали известны в бардовском исполнении). На Ю-Тубе представлена 61 песенная композиция на стихи поэта (дата обращения - 20/05/2019).

Предпринятый нами анализ стихотворного «фона» приводит к выводу, что варьирование предложно-падежных форм в процитированном стихотворении Ю. Левитанского не носит концептуального характера (т.е. не идет речь о смешении «точки отсчета и точки прибытия»), а представляет собой стилистическую фигуру, характерную для авторского идиолекта. Насыщение стихотворения одними и теми же словами, одинаковыми синтаксическими конструкциями принципиально важно - по-

344 Левитанский (1982, с. 217).

345 Шведова (1960, с. 300-309).

346 Лицарева (1994, с. 11-14).

347 Кулле (2011). 
эт «купается» в пришедших на ум словесных коллокациях, а легкое варьирование грамматических форм или порядка слов используется просто «для разнообразия».

Разумеется, нельзя считать расширение текста за счет лексических и синтаксических повторов «изобретением» Юрия Левитанского. Амплификация, т.е. увеличение текста за счет уже сказанного, своего рода «плетение словес», составляет риторический прием, давно известный в мировой литературе. Он наиболее очевиден в народной поэзии (в частности, в песнях), а с психологической точки зрения соответствует экстравертивному типу речевого поведения. И, добавим, наш вывод подтверждает правомерность точки зрения на творческое наследие поэта как на единый, целостный дискурс, на фоне которого и следует изучать то или иное конкретное языковое явление.

Анафорический повтор, сопровождаемый частичным обновлением глагольного управления, - вот суть приема, использованного поэтом в стихотворении «Каждый выбирает для себя». Этот частный случай дополняет наши представления об общих закономерностях процесса порождения текста. Но мы убеждаемся также, что у поэтической речи - своя грамматика, и особенности данного дискурса необходимо учитывать при анализе. Переход от управления как вида синтаксической связи к дискурсивным характеристикам текста вполне правомерен. 


\section{Глава 6. Лексические повторы и случаи прономинафобии в поэзии (существительные против местоимений?) $)^{348}$}

Говорящий иногда бывает вынужден, в соответствии со своими коммуникативными целями, повторить слово в рамках одной реплики, точнее - в рамках высказывания. Такой повтор может быть обусловлен выбранной конструкцией. В первую очередь, очевидно, приходят в голову готовые коллокации, дважды включающие в себя одну и ту же лексему. Имеются в виду фразеологизмы или паремии в классическом понимании этих терминов, типа рус. Стенка на стенку; С глазу на глаз; Рука руку моет, От добра добра не ищут; Бездна бездну призывает... и т.п. С помощью лексического повтора образуются также некоторые типы синтаксических идиом (фразем): Награда есть награда; Париж так Париж; Есть компромиссы и компромиссы; Всем пирогам пирог; Приказ приказу рознь; Драка не драка, а... и т.п. ${ }^{349}$. Во всех этих случаях повтор лексемы является конститутивным условием употребления оборота и выбор ее не зависит от воли говорящего: оборот выбирается целиком. Поэтому в данном случае мы от исследования этих конструкций отвлекаемся.

Повтор слова может также образовывать ряд однородных членов, обозначающий не только множественность предметов, но и множественность, длительность или кратность действий, масштаб пространства, интенсивность свойств и т.д. ${ }^{350}$, ср. цитаты:

Ночь, ночь, ночь лежала над всей страной.

В Черноморском порту легко поворачивались краны... (И. Ильф, Е. Петров. «Двенадцать стульев») 351 .

- Сыр у них грязными носками отдает, Маша! - возражает Дементий Порфирьевич. - Забыла? Вчера на ужин ты подала камамбер - плесень и плесень! (Б.

Кенжеев. «Обрезание пасынков»)352.

Этим ведь в песне тешатся все.

Это ведь значит - пепел сиреневый,

348 Раздел представляет собой переработанное и дополненное исследование, выполненное при поддержке Немецкого научно-исследовательского сообщества (DFG), «Русскоязычная поэзия в транзите»; Трирский университет, Германия, FOR 26o3. Первая публикация: Норман Б. Ю. (2019): Прономинафобия (нелюбовь к местоимениям) и лексические повторы // Уральский филологический вестник. Серия «Язык. Система. Личность: Лингвистика креатива». Вып. 2 (28). Екатеринбург. С. 110-121.

349 Бушуй (1970); Копотев, Стексова (2016) и др.

350 Норман (2016, с. 164-165).

351 Ильф, Петров (1958, с. 402).

352 Кенжеев (2010, с. 188). 
Роскошь крошеной ромашки в росе, Губы и губы на звезды выменивать!

(Б. Пастернак. «Сложа весла») ${ }^{353}$.

По Смоленской дороге - леса, леса, леса, По Смоленской дороге - столбы, столбы, столбы...

(Б. Окуджава. «По Смоленской дороге»)354.

Мылом, мылом, мылом, мылом

Умывался без конца,

Смыл и ваксу, и чернила

С неумытого лица...

(К. Чуковский. «Мойдодыр») 355.

Суть данного речевого приема - в «повышении эффективности прагматического воздействия на адресата» 356 . Вообще повтор лексемы, как известно, используется как сильное стилистическое средство, эмфатически выделяющее какой-то элемент ситуации, концентрирующее внимание на его роли и свойствах. На повторах основываются многие риторические фигуры - такие как анафора, эпифора, хиазм, симплока, анадиплосис и др. Не случайно сегодня и школьных педагогов предостерегают от того, чтобы автоматически считать лексический повтор в тексте речевой ошибкой: он может быть мотивирован авторской интенцией 357 .

Придавая высказыванию особые модальные и эмоционально-экспрессивные оттенки, стилистически и прагматически оправданный повтор, несомненно, имеет художественную ценность и заслуживает внимания лингвистов, но и он сейчас не будет в центре нашего внимания.

Нередко повторяемое слово, сохраняя свой внешний облик (а, бывает, и лексическое значение), относится в реальности к другому референту, т.е., при внешнем совпадении лексем, мы имеем дело с речевой омонимией: $\mathrm{X}_{1} \mathrm{vs}$. $\mathrm{X}_{2}$. Приведем несколько примеров:

И вот котлованы начинают сменяться котлованами, ущелья ущельями... (И.

Бунин. «Иудея»358; т.е. 'одни котлованы начинают сменяться другими котлованами, одни ущелья - другими ущельями').

Справедливость спорила со справедливостью: решать спор должен был закон (М.Л. Гаспаров. «Занимательная Греция»359; 'одна справедливость спорила с другой справедливостью').

353 Пастернак $(1989,1$, с. 129).

354 Окуджава $(1984$, с. 81$)$.

355 Чуковский $(1965,1$, с. 187).

356 Вавилина (2010, с. 17).

357 Мозгалова (2007).

358 Бунин $(1987,3$, с. 541$)$.

359 Гаспаров (2008, с. 71). 
Теперь КГБ переименован, каких-то служащих уволили на пенсию, другие пересели из кресел в кресла (Л. Яновская. «Записки о Михаиле Булгакове» ${ }^{60}$; 'служащие пересели из одних кресел в другие кресла').

Лексическое значение слова в данных примерах сохраняется, но его использование в речи подразумевает наличие в реальности нескольких экземпляров предмета.

Принципиально асимметричная природа языкового знака, способность формы «сползать» по отношению к значению (и наоборот) позволяет видеть в некоторых случаях не лексический повтор как таковой, а только его имитацию ${ }^{361}$. Это значит, что за сходной формой стоит не речевое отнесение одного названия к разным предметам, но языковая омонимия: разные лексико-семантические варианты слова или просто внешне совпадающие слова, ср.:

Эфрос жил театром, жил в театре. Даже свой кабинет перенес в репетиционный зал, подальше от администрации... (Е. Стеблов. «Против кого дружите?»362. В первом случае театр - 'театральное искусство', во втором - 'театральное здание').

С стенных газет вопрос карельский

Глядел и вызывал вопрос

В больших глазах больных берез

(Б. Пастернак. «Высокая болезнь» ${ }^{363}$. В первом случае вопрос - ‘дело, ситуация’; во втором - 'недоумение').

Пусть нечем чаи подсластить,

Отныне не в сладости сладость...

(А. Межиров. «Проводы»364. В первом случае сладость

- 'ощущение сладкого вкуса'; во втором - 'удовольствие').

Этот прием, по достоинству оцениваемый реципиентом, действует по принципу «то же - да не то же». В силу своего эстетического эффекта он активно используется в публицистике - в частности, в качестве газетных заголовков. Несколько примеров из газет конца прошлого века: История с нашей историей («Общая газета». 1995. № 46); Бредущие из ада в ад («Общая газета». 1995. № 47); Как Тина стала Тиной («Аргументы и Факты». 1996. № 44).

Повтор существительного мотивирован также в высказываниях с именными предикатами - при глаголах существования или отношения ${ }^{365}$.

\footnotetext{
360 Яновская (2007, с. 411$)$.

361 Норман (2017а, с. 42-44).

362 Стеблов (2010, с. 125).

363 Пастернак $(1989,1$, с. 560$)$.

364 Межиров (1989, с. 214).

365 Апресян [и др.] (2010, с. 291).
} 
Это слова типа быть, стать, казаться, сделать, превратить, походить, назвать, значить и т.п. Три примера из художественной литературы:

Толмачу этим тунгусским утром выпадает проснуться толмачом в однокомнатной квартирке напротив кладбища (М. Шишкин. «Венерин волос») $)^{366}$.

Утром очнулся и землю землею назвал, Зною подставил еще неокрепшую грудь

(А. Тарковский. «Приазовье») $)^{367}$.

Тоннели рачьи проворней, чем бензин на солнце, и не наблюдаемы. А в голове рака есть всё, что за ее пределами. Порциями человека он входит в человека

(А. Парщиков. «В домах для престарелых...») $)^{368}$.

Все описанные типы лексических повторов - общеизвестны, вполне, можно сказать, легитимны. Они описываются в пособиях по фразеологии, стилистике, грамматике. На их фоне особый интерес вызывают случаи лексического повтора, вступающие в противоречие с правилами организации связного текста. Объектом наших наблюдений далее будут ситуации с намеренным и неправомерным повтором имени существительного в поэтическом произведении. Оборотной стороной этого факта является избегание местоимений 3-го лица. Назовем эту тенденцию прономинафобией (от лат. pronomina 'местоимения' и греч. phobos, pyc. фобия 'боязнь, нетерпимость'). Но сначала нужно обратиться к некоторым понятиям лингвистики текста.

Текст, понимаемый как целостная структура, должен быть когерентным - тематически и прагматически связным, а разнообразные языковые средства - такие, как местоимения, союзы, порядок слов и т.д. - обеспечивают реализацию этой целостности (когезию, или сцепление). Участвует среди этих средств и повтор лексемы, необходимый в информационном плане: для того, чтобы сообщить нечто «новое», говорящий должен оттолкнуться от «старого». Подтвердим это понимание лексического повтора как средства когезии следующей цитатой:

Функционально повторы служат структурированию текста и обеспечивают тем самым его цельность и единство. Повторы связывают новое употребление повторяемого слова с предшествующими и в какой-то мере - через ожидание - с последующими ${ }^{369}$.

366 Щишкин (2006, с. 28).

367 Тарковский (1982, с. 242).

368 Парщиков (2014, с. 65).

369 Супрун (2001, с. 114). 
Вообще повторение, или итерация, - один из основополагающих принципов композиционно-смысловой организации текста: он действует на всех его уровнях, наиболее част на фонологическом, но наиболее ощутим на тех уровнях, которые непосредственно связаны со смыслом. Пронизывающие текст лексические связи очерчивают и проблематику произведения, и развитие его сюжетных линий.

Вместе с тем, если подходить к тексту (особенно небольшому по объему) с точки зрения его лексического богатства, то понятно, что повтор лексемы снижает информационную ценность произведения: он некоторым образом ограничивает его развитие. Неслучайно один из главных «жупелов» стилистики - это упомянутая выше тавтология, неоправданная избыточность выражения, ведущая к многословию и плетению словес. Но повтор повтору рознь: конструкции типа Европа есть Европа или как живой с живыми говоря никак «по ведомству» плеоназма не проходят. Здесь второе употребление лексемы связано с новым смыслом.

Говоря об объективных предпосылках повтора лексемы на ограниченном объеме текста, нельзя еще не упомянуть о таком психологически важном явлении, как инерция номинации в речевой деятельности говорящего. Выбранное слово еще какое-то время сохраняет свою индукционную активность в кратковременной памяти и «вмешивается» в ход речепорождения ${ }^{370}$. Тактика говорящего понятна: если слово уже выбрано и находится в оперативной памяти, почему бы не использовать его еще раз? Результатом такого психологического настроя могут быть неоднократно отмечавшиеся в литературе обмолвки и описки. Австрийский психолог $\Phi$. Кайнц приводил соответствующие примеры в ряду наиболее типичных примеров случаев речевых «сбоев» ${ }^{371}$.

Но язык не случайно развивает в себе разветвленную систему индексальных обозначений: отсылочных слов, местоимений, перифрастических наименований и т.п.:

Когда мы употребляем языковой индекс, то нашим намерением всегда является идентификация (указание) одного и только одного «объекта». И в случае, когда мы возвращаемся к некоторому выражению, употребленному в предшествующем контексте, мы опосредованно указываем на некоторый «объект», тот самый, на который указывает выражение в предшествующем контексте 372 .

Сами эти индексы - семантически не самодостаточны, неполнозначны. Но их отсылочная и идентифицирующая функция делает их полноценными и весьма необходимыми знаками. Общее правило лингвистики текста гласит: повторяемое имя должно быть заменено в высказывании

370 Норман (2009, с. 231-233).

371 Kainz (1967, с. 398-450).

372 Беллерт (1978, с. 187). 
личным местоимением 3-го лица - это элементарное требование грамматической логики и стилистики. С одной стороны, местоимение, заменяющее полнозначную лексему, предотвращает ненужную, неинформативную тавтологию - это его регулярная субституционная роль. С другой стороны, оно отсылает к уже «пройденной» части текста, обеспечивая связность последнего - это его анафорическая функция. Именно в субституции и анафоре видится важнейшее предназначение личных местоимений, а компактность и семантическая обобщенность («на полпути от лексики к грамматике») дополняют их коммуникативную специфику.

В свое время Л. Блумфилд писал, что если посетитель на рынке на предложение «Не хотите ли превосходных спелых дынь?» ответит: «Сколько стоят дыни?» (вместо «А почем они?»), то «этот ответ, вероятно, повлечет за собой задержку реакции или неправильную реакцию («непонимание»)»373. Несоблюдение правила анафорической отсылки помешает развитию диалога.

По сути, субституция и анафора - это общепринятые механизмы речи, элементы речевой техники. Тем не менее, встречаются случаи, когда говорящий нарушает эти правила не по небрежности, а с очевидностью преследуя какие-то свои особые цели. В таком случае избегание личных местоимений становится уже приемом.

Покажем это вначале на примере отрывков из произведений сербского и хорватского писателя (живущего в Берлине) Боры Чосича (перевод В. Соколова). В его знаменитой повести «Роль моей семьи в мировой революции», изданной на многих языках мира, читаем, в частности:

Отец выбросил раскаленный утюг в окно. Отец открыл бутылку пива домашнего производства, пробка вылетела вверх, отец сказал: «Вот это да!» Отец сказал: «Пошли на учения пожарников!»374.

Пришел теткин брат, стали его кормить. Брат рос с огромной скоростью, на брате все трещало. Из нескольких моих старых брюк ему сделали одни, временные. Тетка выставила брата на конкурс, проводимый журналом «Стража на Ядране», на самого толстого ребенка в Югославии. Брат занял второе место... ${ }^{375}$.

Мама вновь принялась страдать от осенней печали. Сначала мама подолгу молчала, потом начинала рыдать. Мама каждую новость сообщала так, будто где-то что-то горит. Мама описывала происшествия, свои сны и так далее... ${ }^{376}$.

Товарищ в сапогах спросила: «Могу ли я приходить в дальнейшем, несмотря на письмо?» Мы ответили: «Можешь!» Товарищ расспрашивала о разных науках рода человеческого, ранее ей абсолютно неизвестных, - например, о штопке377.

373 Блумфилд (1968, с. 273).

374 Чосич (200о, с. 17).

375 Чосич (200о, с. 26).

376 Чосич (200о, с. 112).

377 Чосич (200о, с. 83). 
Я делал с помощью бумаги макет нашего района со всеми домами, в том числе и разрушенными. Я аккомпанировал на пианино товарищу Драгице, которая исполняла русский народный танец, свадебный. Я с помощью ручного пульверизатора, наполненного красными чернилами, написал лозунг «Жизнь прекрасна!» Я играл второго партизана в скетче «Два партизана»... ${ }^{378}$.

В каждом отрывке лицо, о котором идет речь, многократно обозначается с помощью одного и того же существительного (отец, брат, товарищ...), и это повторение цементирует отрывок, придает ему тематическую цельность. Однако привычных грамматических средств когезии - личных местоимений - явно не хватает. В последней же цитате говорящий именует себя с помощью личного местоимения 1-го лица (а, собственно, другой возможности у него и нет), но навязчивое повторение этого я вкупе с синтаксическим параллелизмом фраз тоже создает особый эффект. Он, в принципе, напоминает синдром семантической афазии, когда человек пользуется в своей речи только простыми высказываниями, а логикограмматические связи (причинно-следственные, пространственные, временные и т.п.) ему оказываются недоступны.

Очевидно, что за использованием подобных лексико-грамматических структур стоят определенные эстетические сверхзадачи. Повествование становится фрагментарным и «рассыпчатым»: текст превращается в набор высказываний. Несоблюдение элементарной техники обращает на себя внимание читателя, заставляет его и в дальнейшем ожидать последовательного применения этого приема.

В то же время можно считать, что таким образом делается попытка отразить особенности мировосприятия говорящего. В частности, персонажу Чосича, от лица которого ведется повествование, лет 10-12, и каждое событие в его жизни значимо и самостоятельно. Причинно-следственные, уступительные, присоединительные и прочие связи в его сознании еще не оформились в должной мере.

Намеренный лексический повтор может иметь и иную мотивировку. Обозначение референта с помощью личного местоимения автоматически переводит его в разряд темы, известной части сообщения. Однако если говорящий по-прежнему акцентирует внимание на референте, он может в эмфатических целях воспользоваться повтором лексической номинации, подчеркивая ее рематический характер. Приведем сначала два примера из русской художественной прозы:

Даже голуби были озадачены этим пестрым громом. Даже голуби избегали дом. А о квартирантах и говорить нечего (Л. Кассиль. Кондуит и Швамбрания ${ }^{379}$; ср. возможное: даже они избегали дом).

378 Чосич (200о, с. 86$)$.

379 Кассиль (1979, с. 251). 
Селедку он любит до сих пор. И аккуратно обсасывает хвосты, держа их за хвост. Фу, какой позор! (Э. Лимонов. «...У нас была великая эпоха» ${ }^{80}$; ср. держа рыбу за хвост и т.п.).

Аналогичное явление встречается и в поэзии. Но здесь, напомним, в процесс выбора слова вмешиваются свои дискурсивные факторы: размер и рифма. И в каких-то случаях именно они могут оправдывать повторное употребление лексемы:

Кто время целовал в измученное темя, -

С сыновней нежностью потом

Он будет вспоминать, как спать ложилось время

В сугроб пшеничный за окном

(О. Мандельштам. «1 января 1924») $)^{381}$.

Идея России не где-то в мозгу, не в области некой духовной а здесь, на виду, в неоглядной глуши, в опасном соседстве с душою, не ведающей, где границы души, где собственное, где - чужое

(В. Кривулин. «Идея России») $)^{82}$.

Повтор лексемы время в первой из цитат и душа - во второй обусловлен как смысловой важностью этих слов, так и ритмическим устройством и рифмой стихотворений (темя - время, глуши - души). Следующий пример:

И пока бы паркет в Абзацах сверкал, зеркала, не слишком, но рококо, отражали бы окна, и в каждом окне, а вернее, в зеркальном отраженье окна над застылой рекой поднимался бы пар...

$$
\text { (Л. Лосев. «Роман») })^{383} \text {. }
$$

И здесь: вместо в каждом окне правильней было бы (да простит нас поэт!) сказать в каждом из них, а вместо в зеркальном отраженье окна можно было бы сказать в его отраженье зеркальном... Но что такое для поэта - «правильней»? Он творит по иным законам, вспомним строки Анны Ахматовой:

По мне, в стихах все быть должно некстати, Не так, как у людей...

(А. Ахматова. «Творчество») $)^{384}$.

38 о Лимонов (1989, с. 15).

381 Мандельштам (1990, 1, с. 152).

382 Кривулин (1990, с. 98$)$.

383 Лосев (2019).

384 Ахматова (1987, 1, с. 190). 
Повтор уже использованной лексемы (вместо должного местоимения) входит в палитру изобразительных средств такого поэта-авангардиста, как Александр Пригов.

Посмотри, как жизнь идет -

Встречи разные, разлучки...

Пьяного ведут под ручки,

Вот дитя бежит за пьяным,

Как проглядывает явно

Перст судьбы сквозь этот случай!

(Д. Пригов. «Франц Кафка»)385.

Прокомментируем и этот пример. Если лексема пьяный в 3-й строке вполне оправдана, то в 4-й она, по правилам стилистики, должна была бы быть заменена на личное местоимение (бежит за ним). Но поэту важнее выдержать ритм и рифму, а логикой связного текста концептуалист может и пренебречь.

Известно, что стилистически «смягчить» лексический повтор говорящий может с помощью частицы же, да еще в комбинации с указательным местоимением или наречием (тот же, такой же, там же, так же и т.п.) - эта идентифицирующая функция частицы еще недостаточно описана в научной литературе. Однако заметим, во-первых, что употребление этой частицы не обязательно приводит к элиминации полнозначного слова, см. прозаический пример:

- Пистолеты той эпохи. Системы знаменитого оружейника Лепажа. Пушкин знал и любил хорошее оружие. У него были такие же пистолеты... (С. Довлатов. «Заповедник» ${ }^{86}$; ср. возможное: у него были такие же).

А, во-вторых, говорящий иногда сознательно избегает употребления «смягчающей» частицы - по-видимому, с указанной уже целью сохранения логического ударения на полнозначной лексеме (не обязательно существительном). Приведем пример с повтором наречия:

- Сам виноват, что пришлось прятаться... - сказала она и машинально поправила юбку, машинально заметив, что пассажир, появившийся в углу, - молодой человек в очках, - смотрит на голый шелк ее ног (В. Набоков. «Король, дама, валет» ${ }^{87}$; ср. возможное: так же машинально заметив, что... или машинально же заметив, что...).

Уже по приведенным выше цитатам заметно, что особую роль играет тавтологическое употребление лексемы в поэтических текстах. Не случайно

385 Пригов (1996, с. 188-189).

386 Довлатов (1993, 1, 360).

387 Набоков (1990, 1, с. 118). 
появляются исследования, посвященные функциям повторов в творчестве отдельных поэтов ${ }^{38}$. Здесь повторяющееся слово или целое выражение если и не приобретает характер ключевого, то, во всяком случае, «тянет на себя» лоскутное одеяло смысла. Несколько новых примеров, начиная с русской классики:

В моих садах - цветы, в твоих - печаль.

Приди ко мне, прекрасною печалью

Заворожи, как дымчатой вуалью,

Моих садов мучительную даль

(Н. Гумилев. «Беатриче») ${ }^{389}$.

Повтор слова печаль необходим по крайней мере потому, что при втором употреблении к нему прибавляется эпитет прекрасная. А вторичное упоминание «моих садов» менее обязательно, но и оно не выглядит навязчивым. В первом случае мои сады - это место, локус, во втором - определение к объекту (мучительная даль).

Современных же авторов лексические повторы вообще не смущают, независимо от синтаксической роли этих слов и от эстетической программы самих авторов. Сравним цитаты:

Сколько я поговорок

Сложил в коробок лубяной,

Чтобы шарили дети

В моем лубяном коробке...

(А. Тарковский. «Сверчок») $)^{390}$.

Стой тихонько, не двигайся, жди.

Потерпи, я приду за тобою..

$\mathrm{O}$, как поле блестит впереди

С огибающей поле тропою!

(А. Кушнер. «Сам себе говорю: не мешай»)391.

Если у дерева тень зацветет, то засохнет дерево тут же, а тень уподобится язве, почву бесплодьем отравит и даже не охнет сделает смерть откровенной убийцей

(И. Жданов. «Ревность») 392 .

Послушай ночь. Опять гремят подковы, И курс вдовы читают детям вдовы...

388 Метлякова (2001); Ковтунова (2006); Минакова (2012) и др.

389 Гумилев (1988, с. 147).

390 Тарковский (1982, с. 45).

391 Кушнер (2013, с. 97).

392 Жданов (1991, с. 96). 
И ставят двойки тем, кто не убит

(М. Шелехов. «Ангел уличный») 393 .

Я увидел - двое лежат в лощине

на рыхлой тине в тине, лопатки сильные у мужчины, у нее - коралловые ступни...

(А. Парщиков. «Землетрясение в бухте Цэ»)394.

Иду-бреду обутый в глину, мальчишка, выросший из глины, и узнают меня осины как перехожую осину

(Ю. Казарин. «Иду-бреду обутый в глину...») $)^{395}$.

...Тот знает, как небесно хороши с попойки возвращения в Коломне. Как хорошо Коломною ночной, Коломною и за полночь не темной, В Коломну от товарищей домой домой идти, идти домой Коломной (Л. Лосев. «Ружье») ${ }^{396}$.

В последнем стихотворении сознательное нагнетание названия Коломна отдает намеренной игрой в слова, амплификацией, но это, конечно, игра с читателем, с его представлением о стандартных грамматических структурах. Поэт как бы вообе забывает о личных местоимениях с их субституционной и анафорической функциями: он живет в мире называемых по имени реалий. И его ничуть не смущает возвращение к уже «пройденной» лексике; скорее наоборот, оно таит в себе элемент переклички с читателем, своего рода озорства, «подмигивания» («Если нельзя, но очень хочется, то можно»).

Для известного «метаметафориста» Александра Еременко лексический повтор в пределах фразы становится текстообразующим приемом. Приведем несколько примеров из цикла «Невенок сонетов»397.

Сегодня я задумчив, как буфет, и вынимаю мысли из буфета, как длинные тяжелые конфеты из дорогой коробки для конфет.

393 Шелехов (1991, с. 145).

394 Парщиков (2014, с. 33).

395 Казарин (2014, с. 450).

396 Лосев (2000а, с. 148).

397 Еременко (2019). http://modernpoetry.ru/main/aleksandr-eremenko-izbrannoe (10/08/2019). 
На раскладушке засыпает Фет, и тень его, косящая от Фета, сливаясь с тенью моего буфета, дает простой отчетливый эффект...

Здесь все рассчитано на десять тысяч лет, и длится электрическое лето над рыбьим жиром тусклого паркета, чтоб мы не наступили на паркет.

Нас будут заворачивать в пакет, чтоб ноги не торчали из пакета, согласно положений этикета...

И, кнопкой канцелярскою пришпилен к осенней ветке книзу головой, висит и размышляет головой, зачем в него с такой ужасной силой вмонтирован бинокль полевой...

И в других своих произведениях Еременко использует тот же прием:

Я сидел на горе, нарисованной там, где гора.

У меня под ногой (когда плюну - на них попаду) шли толпой бегуны в непролазном и синем аду... («Иерониму Босху») $)^{398}$.

Двоятся и пляшут, и скачут со стен зеленые цифры, пульсируют стены... («Ночная прогулка») $)^{399}$.

Потусторонний взгляд. Им обладал Эйнштейн. Хотя, конечно, в чем достоинство Эйнштейна? Он, как пустой стакан, перевернул кронштейн, Ничуть не изменив конструкции кронштейна («К вопросу о длине взгляда») ${ }^{400}$.

Вкупе с некоторым косноязычием (тень, косящая от Фета; согласно положений; книзу головой; размышлять головой: скачут со стен) лексические повторы могут навести на мысль о речевой небрежности, невнимательности автора. Но это - кажущееся впечатление. На деле перед нами - выверенный прием и авторская «метка». Кстати, не случайно, что во

398 Еременко (2019). http://modernpoetry.ru/main/aleksandr-eremenko-izbrannoe (10/08/2019).

399 Еременко (2019). http://modernpoetry.ru/main/aleksandr-eremenko-izbrannoe (10/o8/2019).

400 Еременко (2019). http://modernpoetry.ru/main/aleksandr-eremenko-izbrannoe (10/08/2019). 
многих случаях повторяющаяся лексема находится в сильной позиции, замыкая собой строку! Это значит, что поэт отдает себе отчет в своем словесном озорстве.

Итак, для стихотворений А. Еременко случаи лексических повторов и прономинафобии характерны, бросаются в глаза. У других поэтов они встречаются с меньшей регулярностью. Конечно, в поэзии действуют дополнительные, особые факторы создания теста: стихотворный размер, рифма, анафония... Но и в этом наборе средств лексический повтор обращает на себя внимание. Нарушение принципа связности текста (несоблюдение правил субституции и анафоры) должно компенсироваться эстетической сверхзадачей.

Характерно, что в рассмотренных случаях писатель или поэт отказывается не только от стандартной (предусмотренной законами построения текста) замены имени местоимением 3-го лица, но и от применения лексических субститутов (синонимов, гиперонимов и т.п.). Очевидно, он видит особый смысл именно в воспроизведении уже использованного слова (хотя думается, что степень осознанности данного приема невелика и зависит от разных условий, в том числе от творческой манеры автора). Естественно, между лексической итерацией и прономинафобией - обратная зависимость: чем больше в тексте именных повторов, тем меньше необходимости в местоимениях 3-го лица с их анафорической и субституционной ролью.

Таким образом, в описанном материале мы имеем дело с систематическим сознательным отказом от использования личных местоимений в их типичной функции и, тем самым, с нарушением основополагающего принципа когезии. Каждое высказывание в таком случае представляется как информационно самодостаточное и изолированное. Можно было бы сказать, что языковые единицы тут предпочитаются речевым, что речи в строгом смысле слова здесь нет. Однако не следует забывать, что лексический повтор тоже по-своему работает на целостность текста, на его когерентность: повторяющиеся слова («лексическая когезия») выступают в качестве своего рода скреп, и довольно наглядных. Подтверждается отчетливо высказанная М.Л. Макаровым мысль о том, что когерентность объемнее когезии: «Когерентность шире когезии, она охватывает не только формально-грамматические аспекты высказываний, но и семантико-прагматические (тематические и функциональные в том числе) аспекты смысловой и деятельностной (интерактивной) связности дискурса» ${ }^{401}$.

Но главное - мы видим, что случаи прономинафобии в речи говорящего сталкиваются с ожиданиями слушающего, который настроен на восприятие привычного для него связного текста, с использованием личных местоимений. Это не всегда и не сразу замечается адресатом, но мо-

401 Макаров (2003, с. 194). 
жет накапливать психологическое напряжение и порождать эстетический эффект. Среди известных принципов коммуникации П. Грайса есть два взаимосвязанных постулата: Постулат Количества («Не сообщай больше информации, чем требуется») и Постулат Способа («Будь краток; избегай ненужного многословия»). Повтор номинации, разумеется, снижает информационную ценность текста. Однако если слушающий убежден в достаточной языковой компетенции говорящего, то он вынужден «предполагать наличие какой-то особой цели, особого смысла в передаче этой лишней информации» ${ }^{402}$. В нашем случае дело обстоит именно так. Преднамеренное насыщение текста одной и той же лексемой оправдано как особыми дискурсивными условиями, так и расчетом на получение дополнительного эстетического эффекта.

Современная русскоязычная поэзия, использующая весь доступный ей арсенал языковых средств, нередко балансирует на грани общепринятых законов построения текста. Но это право даровано ей особой природой художественного дискурса. Вместе с тем, для лингвиста такие отступления от нормы представляют большой интерес, потому что позволяют лучше понять саму природу средства общения.

402 Грайс (1985, с. 222). 


\section{Заключение}

Работа в исследовательском проекте «Русскоязычная лирика в переводе: поэтические формы общения в границах жанра, языка, культуры и общества между Европой, Азией и Америкой» убедила меня в том, что в разных странах, в разных культурах люди вкладывают в понятие «поэзия» очень разные вещи. Например, русская поэзия, с ее ритмикой и рифмой (я беру сейчас наиболее традиционные формы поэзии) разительным образом не похожа на китайскую, в которой доминирует сочетание звукового и зрительного образов слова - без, однако, привычных русскому уху и глазу черт.

Однако поэзия есть у любого народа - без нее невозможно представить себе все многообразие жизни. С помощью, казалось бы, обычных, привычных нам слов поэт создает особый мир. Здесь звезда говорит со звездою (М. Лермонтов), а кастрюли могут кричать (О. Григорьев). Здесь деревья оказываются деревянными, а камни - каменными (С. Кирсанов). Здесь скрипки скрипят, а пищали пищат (О. Лосев). Здесь родился такой зоологический мутант, как стрекозел (впервые у В. Маяковского) и такое чудо ботаники, как фиги-финики (у К. Чуковского)...

Порождение текста - вообще многоканальный процесс, в котором задействованы все уровни языковой системы. Они координируют свои усилия и сложным образом взаимодействуют. В чем же специфика порождения поэтического текста?

Во-первых, в этом процессе - заметно бо́льшая доля участия единиц фонетического уровня. Во-вторых, поэтическое творчество отличается бо́льшей свободой в выборе и употреблении слов (единиц лексикона) и словообразовательных элементов. В-третьих, предложение как каноническая единица синтаксической организации речи вынуждена отстаивать свой статус, борясь со стихотворной строкой.

Даже классические грамматические категории, известные обязательностью («принудительностью») своего исполнения, - такие, как падеж, предоставляют человеку, пишущему стихи, (и его читателю) значительную свободу действий: это связано с перестройкой отношений между лексикосемантическими классами слов. У поэтического творчества есть черты, роднящие его со спонтанной устной речью: это обширные семантико-синтаксические преобразования, происходящие в сознании носителя языка. То, что скрывается между строк, поглощается целостной конструкцией, - то восстанавливается читателем в меру его опыта и желания, - и процесс творчества (как и удовольствие от него) оказывается обоюдным. 
С лингвистических же позиций можно повторить, что не столько поэт использует язык, сколько язык эксплуатирует поэта, чтобы выявить и продемонстрировать всю совокупность своих возможностей, весь потенциал своей системы. В этом - огромная ценность поэзии как объекта исследования для лингвиста. 


\section{Список цитированной литературы}

Абдуллаев Е. (2018): Тихая речь (поэзия в эпоху массмедиа) // Арион. Журнал поэзии. № 4. С. 16-24.

Аверинцев С.С. (1979): Классическая греческая философия как явление историко-литературного рода. В кн.: Новое в современной классической филологии / Ред. С.С. Аверинцев. М.: Наука. С. 41-81.

Аверинцев С. (1990): Судьба и весть Осипа Мандельштама. В кн.: Мандельштам О. Сочинения в двух томах. Том 1. Стихотворения, переводы. М.: Художественная литература. С. 5-64.

Авчиева Т.А. (2015): Анжамбеман как сильный стилистический прием поэтов XXI века // Известия Дагестанского государственного педагогического университета. Общественные и гуманитарные науки. № 1. С. 47-49.

Адмони В.Г. (1994): Система форм речевого высказывания. СПб.: Наука.

Адмони В. (1984): Из долготы дней. Стихотворения 1925-1983. Л.: Советский писатель.

Апресян Ю.Д. [и др.] (2010): Теоретические проблемы русского синтаксиса: Взаимодействие грамматики и словаря. М.: Языки славянских культур.

Аронов А. (1987): Островок безопасности. Книга стихов. М.: Советский писатель.

Ахапкин Д. Н. (2002): «Филологическая метафора» в поэзии И. Бродского. Автореферат диссертации... кандидата филологических наук. СПб.

Ахматова А. (1987): Сочинения в двух томах. М.: Художественная литература.

Бабенко Л.Г. (ред.) (2002): Русские глагольные предложения: Экспериментальный синтаксический словарь. М.: Флинта - Наука.

Бахтин М.М. (1979): Эстетика словесного творчества. М.: Искусство.

Беллерт И. (1978): Об одном условии связности текста. В кн.: Новое в зарубежной лингвистике. Выпуск VIII. Лингвистика текста. М. Прогресс. С. 172-207.

Берестов В. (1977): Школьная лирика. М.: Детская литература.

Битов А. (1986): Статьи из романа. М.: Советский писатель.

Блумфилд Л. (1968): Язык. М.: Прогресс.

Британишский В. (1985): Движение времени. Книга стихов. М.: Советский писатель.

Бродский И. (1992): Форма времени: Стихотворения, эссе, пьесы. В двух томах. Минск: Эридан.

Бунин И. (1987): Собрание сочинений в шести томах. М.: Художественная литература.

Буслаев Ф.И. (1959): Историческая грамматика русского языка. М.: Учпедгиз. Бушуй А.М. (1970): К вопросу о фразеологической тавтологии // Труды Самаркандского университета. Вып. 194. С. 239-349. 
Быков Д. (2010): Борис Пастернак («Жизнь замечательных людей»). М.: Молодая гвардия.

Быстрова Л.В., Левицкий В.В. (1973): Фонетическое сходство семантически связанных слов // Zeitschrift für Phonetik, Sprachwissenschaft und Kommunikationsforschung. Band 26. Heft 6. C. 591-601.

Вавилина Т.Ю. (2010): Лексемный повтор в аспекте деривации. В кн.: Проблемы динамической лингвистики. Материалы Международной научной конференции, посвященной 8о-летию проф. Л.Н. Мурзина (Пермь, 12-14 мая 2010 г.) Пермь: Издательство Пермского университета. С. 14-21.

Винокур Г.О. (1959): Избранные работы по русскому языку. М.: Учпедгиз. Винокуров Е. (1965): Характеры. М.: Советский писатель.

Вознесенский А. (1975): Дубовый лист виолончельный: Избранные стихотворения и поэмы. М.: Художественная литература.

Вознесенский А. (1976): Витражных дел мастер. М.: Молодая гвардия.

Волков С. (2004): Диалоги с Иосифом Бродским. М.: Эксмо.

Воллис А. (2018): Созерцание. Сборник стихов. М.: Гнозис.

Высоцкий В. (1993): Избранное. Минск: Мастацкая літаратура.

Голанова Е.И. (1989): Как возникают названия. Книга для учащихся старших классов. М.: Просвещение.

Гаспаров М.Л. (2008): Занимательная Греция: Рассказы о древнегреческой культуре. М.: Новое литературное обозрение.

Гаспаров М.Л. Скулачева Т.В. (2003): Односложные слова в стихе: ритм и части речи // Русский язык в научном освещении. № 1 (5). С. 35-50.

Герд А.С. (ред.) (2010): Профессор Валерий Михайлович Мокиенко. К 7олетию. СПб.: Санкт-Петербургский государственный университет.

ГИКРЯ - Генеральный интернет-корпус русского языка - www.webcorpora.ru Гончаренко С.Ф. (1995): Символическая звукопись: квазиморфема как «внутреннее слово» в процессе поэтической коммуникации. В кн.: Язык - система. Язык - текст. Язык - способность. Сб. статей к 6олетию Ю.Н. Караулова / Ред. Ю.С. Степанов и др. М.: Институт русского языка РАН. С. 161-17о.

Грайс П. (1985): Логика и речевое общение. В кн.: Новое в зарубежной лингвистике. Вып. 16. М.: Прогресс. С. 217-237.

Граудина Л.К., Ицкович В.А., Катлинская Л.П. (1976): Грамматическая правильность русской речи: Опыт частотно-стилистического словаря вариантов. М.: Наука.

Григорьев В.П. (1977): Паронимия. В кн.: Языковые процессы современной русской художественной литературы. Поэзия / Отв. ред. А.Д. Григорьева. М.: Наука. С. 186-239.

Григорьев В.П. (1979): Поэтика слова. На материале русской советской поэзии. М.: Наука. 
Григорьев В.П. (1983): Грамматика идиостиля: В. Хлебников. М.: Наука. Григорьев О. (2015): Птица в клетке. Стихи и проза. СПб.: Издательство Ивана Лимбаха.

Гумилев Н. (1988): Стихотворения и поэмы («Библиотека поэта. Большая серия»). Л.: Советский писатель.

Державин Г.Р. (1866): Сочинения Державина с объяснительными примечаниями Я. Грота. СПб.: Издание Императорской Академии Наук.

Довлатов С. (1993): Собрание прозы в трех томах. СПб.: Лимбус-пресс.

Долина В. (1981): Читая Цветаеву. http://www.bards.ru/archives/part. php?id=2709 (10/08/2019).

Долина В. (2018): Серебряный мизинец. М.: Время.

Дударева Я.А. (2012): Номинативные единицы с близким значением как компоненты ассоциативно-вербальной сети носителей русского языка. Автореферат диссертации... канд. филологических наук. Кемерово.

Евтушенко Е. (1980): Избранные произведения в двух томах. М.: Художественная литература.

Еременко А (2019): Избранное - http://modernpoetry.ru/main/aleksandreremenko-izbrannoe (12/03/2019).

Есенин С. (1983): Избранные сочинения («Библиотека классики»). М.: Художественная литература.

Если не Пушкин, то кто: какие стихи ищут в интернете (2015) https://yandex.ru/company/researches/2015/ya_poetry (24/04/2019).

Жданов И. (1991): Место земли: Стихотворения. М.: Молодая гвардия.

Заболоцкий Н. (1983): Собрание сочинений в трех томах. М.: Художественная литература.

Звегинцев В.А. (1996): Мысли о лингвистике. М.: Издательство Московского университета.

Золотова Г.А. (1988): Синтаксический словарь. Репертуар элементарных единиц русского синтаксиса. М.: Наука.

Зубова Л.В. (2000): Современная русская поэзия в контексте истории языка. М.: Новое литературное обозрение.

Зубова Л.В. (2009): Глагольная валентность в поэтическом познании мира. В кн.: Язык как медиатор между знанием и искусством. Сборник докладов международного научного семинара «Проблемы междисциплинарных исследований художественного текста» / Ред. Н.А. Фатеева. М.: Азбуковник. С. 39-55.

Зубова Л.В. (2010): Языки современной поэзии. М.: Новое литературное обозрение.

Зубова Л. (2012): Платье. Стихи. СПб.: Геликон-Плюс. 
Зубова Л.В. (2017): Анжамбеман и грамматика. В кн.: Грамматические исследования поэтического текста: Материалы международной научной конференции (7-10 сентября 2017 г.). Петрозаводск: Издательство Петрозаводского государственного университета. С. 29-35.

Ионова И.А. (1988): Морфология поэтической речи. Кишинев: Штиница. Ильф И., Петров Е. (1958): Двенадцать стульев. Золотой теленок. Записные книжки Ильфа. Воронеж: Коммуна.

Илюшин Е. (2011): Русский стих (вопросы изучения). М.: Издательство Московского университета.

Казарин Ю. (1991): Погода. Из трех тетрадей. Свердловск: Средне-Уральское книжное издательство.

Казарин Ю. (2002): Побег. Стихотворения. Екатеринбург: Издательство Уральского университета.

Казарин Ю. (2006а): Избранные стихотворения (1976-2006). Екатеринбург: МАрАфон.

Казарин Ю. (2006б): Пловец. Екатеринбург: Издательский дом «Союз писателей».

Казарин Ю. (2009): Каменские элегии. Стихотворения. Екатеринбург: Издательство Уральского университета.

Казарин Ю. (2014а): Глина. М.: Русский Гулливер.

Казарин Ю. (2014б): Иду-бреду обутый в глину... // Русский міръ. Пространство и время русской культуры. № 9. С. 450.

Калачева С.В. (1977): Выразительные возможности русского стиха. М.: Издательство Московского университета.

Карпов В.А. (1992): Язык как система. Минск.

Карпов В. (2000): Амальгама. Стихотворения. Минск: Петит.

Кассиль Л. (1979): Повести. Рассказы. М.: Правда.

Катаев В. (1981): Алмазный мой венец. Повести. М.: Советский писатель.

Кенжеев Б. (2010): Обрезание пасынков. М.: АСТ, Астрель.

Кенжеев Б. (2011): Крепостной остывающих мест. М.: Время.

Кибрик А. Е. (1968): Опыт экспериментального определения степени отмеченности слов. В кн.: Семантические и фонологические проблемы прикладной лингвистики (Публикации Отделения структурной и прикладной лингвистики. Вып. 3). М.: Издательство Московского университета. С. 135-164.

Кирсанов С. (1974-1976): Собрание сочинений в 4 томах. М.: Художественная литература.

Клименко А. П. (1974): Лексическая системность и ее психолингвистическое изучение. Учебное пособие. Минск: Минский государственный педагогический институт иностранных языков.

Кобозева И.М. (200о): Лингвистическая семантика. М.: Эдиториал УРСС. Ковтунова И. И. (1986): Поэтический синтаксис. М.: Наука. 
Ковтунова И.И. (2006): Функции композиционных повторов в стихах А. Блока. В кн.: Художественный текст как динамическая система. Материалы Международной научной конференции, посвященной 80летию В.П. Григорьева. М.: Азбуковник. С. 348-355.

Коновалов Е. (2018): Словесная алгебра и цифровая гармония // Арион. Журнал поэзии. № 4 (100). М. С. 36-53.

Копотев М.В., Стексова Т.И. (2016): Исключение как правило. Переходные единицы в грамматике и словаре. М.: Языки славянской культуры. Коровин А. (2018): Тульское захолустье //Арион. Журнал поэзии. 4. С. 13. Кривулин В. (1990): Идея России // Вестник новой литературы. № 1. С. 98-107. Кузнецов С.А. (ред.) (1998): Большой толковый словарь русского языка. СПб.: Норинт.

Кузнецов Ю. (1968): Атомная сказка - https://omiliya.org/article/atomnayaskazka-yuriy-kuznecov (12/o7/2019).

Кулле В. (2011): Поэт личного стыда // Новый мир. № 11 - http://magazines.russ.ru/novyi_mi/2001/11/kull.html (14/03/2019).

Кушнер А. (1981): Канва. Из шести книг. Л.: Советский писатель.

Кушнер А. (1986): Стихотворения. Л.: Художественная литература.

Кушнер А. (1991): Аполлон в снегу. Заметки на полях. Л.: Советский писатель. Кушнер А. (2013): Вечерний свет. Книга новых стихов. СПб.: Издательская группа «Лениздат».

Кушнер А. (2018): Несчастны все, и самые счастливые... // Арион. Журнал поэзии. 4. С. 58.

Ларин Б.А. (1974): Эстетика слова и язык писателя. Избранные статьи. Л.: Художественная литература.

Левин Л. (2007): Песни неба и земли. Избранные стихотворения 19832006 годов. М.: Новое литературное обозрение.

Левин Ю. И. (1966): О некоторых чертах плана содержания в поэтических текстах. В кн.: Структурная типология языков. М.: Наука. С. 199-215.

Левитанский Ю. (1959): Не брести мне сушею... - http://rupoem.com/poets/levitanskij (20/08/2019).

Левитанский Ю. (1982): Избранное. М.: Художественная литература.

Леонтьев А.А. (ред.) (1977): Словарь ассоциативных норм русского языка. М.: Издательство Московского университета.

Лермонтов М.Ю. (1961-1962): Собрание сочинений в четырех томах. М.-Л.: Издательство Академии наук СССР.

Лимонов Э. (1989): ...У нас была великая эпоха // Знамя. № 11. С. 4-77.

Лихачев Д.С. (1984): Послесловие. В кн.: Адмони В. Из долготы дней. Стихотворения 1925- 1983. Л.: Советский писатель. С. 78-83. 
Лицарева К.С. (1994): Творчество Ю.Д. Левитанского в контексте современной поэзии (Проблематика. Поэтика). Автореферат диссертации... кандидата филологических наук. М.: Московский педагогический государственный университет.

Лосев А.Ф. (1981): О понятии языковой валентности // Известия АН СССР. Серия литературы и языка. Т. 40. № 5. С. 403-412.

Лосев Л. (1996): Русская ночь // Знамя. № 5. С. 6.

Лосев Л. (2000а): Ружье // Звезда. № 5. С. 143-148.

Лосев Л. (200об): Собранное. Стихи. Проза. Екатеринбург: У-Фактория.

Лосев Л. (2019): Роман - https://45parallel.net/lev_losev/stihi/\#roman (o1/o7/2019).

Лотман Ю. М. (1970): Структура художественного текста. М.: Искусство.

Луговской В. (1966): Стихотворения и поэмы («Библиотека поэзии. Большая серия»). М.-Л.: Советский писатель.

Лузина Л.Г. (1985): Структурно-семантические особенности стихотворного текста. В кн.: Структура и функционирование поэтического текста. Очерки лингвистической поэтики. М.: Наука. С. 16о-175.

Лурия А. Р. (1975): Основные проблемы нейролингвистики. М.: Издательство Московского университета.

Макаров М. (2003): Основы теории дискурса. М.: Гнозис.

МакКормак Э. (1990): Когнитивная теория метафоры. В кн.: Теория метафоры: Сборник / Сост. Н.Д. Арутюновой. М.: Прогресс. С. 358-386.

Малов В. И. (2001): Лингвистическое исследование асемантичного текста. Автореферат диссертации... кандидата филологических наук. Екатеринбург.

Мандельштам О. (1974): Стихотворения («Библиотека поэзии. Большая серия»). Л.: Советский писатель.

Мандельштам О. (1990): Сочинения в двух томах. М.: Художественная литература.

Мартинович Г.А. (1993): Опыт комплексного исследования данных ассоциативного эксперимента // Вопросы психологии. № 2. С. 93-99.

Маршак С. (1958-1959): Сочинения в четырех томах. М.: Госиздат.

Матвеева Н. (1966): Душа вещей. М.: Советский писатель.

Матяш С.А. (2015): Еще раз о проблеме выявления стихотворных переносов (enjambements) // Вестник Оренбургского гос. ун-та. 2015. № 11. С. 26-33. Маяковский В.(1960): Избранные произведения в двух томах. М.: Государственное издательство художественной литературы.

Межиров А. (1989): Избранное. М.: Художественная литература.

Мерман М. (2007): Двоеточие. М.: Октопус. 
Метлякова Е.В. (2001): Лексический повтор как семантико-стилистическая категория организации лирического текста в раннем творчестве Анны Ахматовой. Автореферат диссертации... кандидата филологических наук. Ижевск.

Мечковская Н. (2001): «И пространство торчит прейскурантом». Число и слово в поэтике Иосифа Бродского. В кн.: Количественность и градуальность в естественном языке. Quantität und Graduierung in der natürlichen Sprache / Herausgegeben von A. Kiklevič. München: Verlag Otto Sagner. C. 97-122.

Минакова А.А. (2012): Типы и функции повторов в поэтических текстах Евгения Евтушенко. Автореферат диссертации... кандидата филологических наук. Майкоп.

Миронова Н.И. (2011): Ассоциативный эксперимент: методы анализа данных и анализ на основе универсальной схемы // Вопросы психолингвистики. № 2 (14). С. 108-119.

Митяев О. (1990): Француженка - http://www.bards.ru/archives/part.php?id $=9731(12 / 08 / 2019)$.

Мозгалова Н.В. (2007): Лексический повтор: всегда ли это речевая ошибка? // Русский язык. № 9. С. 5-6.

Мокиенко В.М. (1997): Ростки безвременья. СПб.: Издательство СанктПетербургского государственного университета.

Мориц Ю. (1974): Суровой нитью. Книга стихов. М.: Советский писатель. Набоков В. (1920): Как воды гор, твой голос горд и чист... - http://poezia.gatchinazooo.ru/nabokov/kak-vody-gor-tvoy-golos-gord-ichist.htm (10/o8/2019).

Набоков В. (1990): Собрание сочинений в четырех томах. М.: Правда.

Николина Н.А. (2009): Метаязыковая рефлексия в современной поэтической речи. В кн.: Обыденное метаязыковое сознание: онтологические и гносеологические аспекты. Часть II. Коллективная монография / Отв. ред. Н.Д. Голев. Томск: Издательство Томского государственного педагогического университета. С. 336-353.

НКРЯ - Национальный корпус русского языка - www.ruscorpora.ru .

Норман Б.Ю. (1975): Слово в грамматике. В кн.: Методы изучения лексики / Под ред. А.Е. Супруна. Минск: Издательство БГУ им. В.И. Ленина. C. 119-133.

Норман Б. Ю. (1994): Грамматика говорящего. СПб.: Издательство СанктПетербургского университета.

Норман Б. (2003): К восприятию современного художественного текста (на материале стихотворения О. Мандельштама «Куда мне деться в этом январе?») В кн.: Człowiek. Świadomość. Komunikacja. Internet / Red. L. Szypielewicz. Warszawa. C. 132-139. 
Норман Б.Ю. (2008): Дружить с кем, дружить против кого, дружить о чем... (взгляд на расширение круга приглагольных актантов) // Studia Slavica Savariensia. 1-2. Szerkesztők: Gadányi Károly. Szombathely. C. $293-307$.

Норман Б.Ю. (2009): Лексический повтор как дискурсивная тактика. В кн.: Лингвистика креатива. Коллективная монография / Отв. ред. Т.А. Гридина. Екатеринбург: Уральский государственный педагогический университет. С. 230-244.

Норман Б.Ю. (2011а): Глагольное управление как многофакторный феномен. В кн.: Дискурс, культура, ментальность: коллективная монография / Отв. ред. М. Ю. Олешков. Нижний Тагил: Нижнетагильская государственная социально-педагогическая академия. С. 242 - 254.

Норман Б. Ю. (2011б): Основы психолингвистики. Минск: БГУ.

Норман Б.Ю. (2012а): Игра на гранях языка. 2-е издание. М.: Флинта.

Норман Б.Ю. (2012б): Лингвистика поэзии: прозрения и заблуждения. В кн.: Лингвистика креатива. Коллективная монография / Под ред. Т. А. Гридиной. Екатеринбург. С. 177-198.

Норман Б.Ю. (2012в): О процессах синтаксической компрессии в современных славянских языках // Известия Российской Академии Наук. Серия литературы и языка. Том 71. № 6. С. 3-11.

Норман Б.Ю. (2016): Жизнь словоформы. Учебное пособие. М.: ФлинтаНаука.

Норман Б.Ю. (2017а): Выбор формы или выбор смысла? (К развитию коммуникативной стратегии в ходе речевого акта). В кн.: Язык. Текст. Дискурс. Научный альманах. Вып. 15. Ставрополь. С. 40-47.

Норман Б.Ю. (2017б): Прагматический потенциал русской лексики и грамматики. Екатеринбург - Москва: Кабинетный ученый.

Норман Б.Ю. (2018): «Необязательный» дательный падеж при русском глаголе // Вестник Томского гос. ун-та. Филология. № 53. С. 61-74.

Норман Б.Ю., Куссе Х. (2018): Лингвистика в саду. Введение в теорию семантической инвариантности. Екатеринбург-Москва: Кабинетный ученый.

Норман Б.Ю., Мухин М.Ю. (2016): О синтаксическом компоненте лексической семантики // Slavistična revija, letnik 64, št. 1. C. 1-12.

Окуджава Б. (1967): Март великодушный. М.: Советский писатель.

Окуджава Б. (1984): Стихотворения. М.: Советский писатель.

Олейников Н. (1990): Пучина страстей: Стихотворения и поэмы. Л.: Советский писатель.

Орлов В. (1990): Близкие слова // Книжное обозрение. № 22 (1 июня).

Осипов Б. (2014): Про женщин. Стихи без примечаний. Омск: Вариант-Омск.

Павлов О. (1998): Степная книга - https://libking.ru/books/prose-/prosecontemporary/192998-oleg-pavlov-stepnaya-kniga.html (14/o8/2019). 
Павлова В. (2004): По обе стороны поцелуя: Книга новых стихотворений. СПб.: Пушкинский фонд.

Павлова В. (2008): Письма в соседнюю комнату: Тысяча и одно объяснение в любви. М.: АСТ: ХРАНИТЕЛЬ.

Панов М.В. (1966): Русский язык. В кн.: Языки народов СССР в пяти томах. Том 1. Индоевропейские языки / Отв. ред. В.В. Виноградов. М.: Наука. С. 55-122.

Панов М.В. (1998): Тишина. Снег. М.: Carte Blanche.

Панов М.В. (2011): Олени навстречу. Вторая книга стихов. М.: Carte Blanche.

Парщиков А. (2014): Дирижабли. М.: Время.

Пастернак Б. (1989-1992): Собрание сочинений в пяти томах. М.: Художественная литература.

Петрушевская Л. (2010): Рассказы о любви. М.: Астрель.

Пешковский А.М. (1956): Русский синтаксис в научном освещении. Изд. 7-е. М.: Учпедгиз.

Полозкова В. (2012): Непоэмание. M.: Livebook.

Поэты о русском языке (1989): Изд. 2-е. Воронеж: Издательство Воронежского университета.

Пригов Д.А. (1996): Собрание стихов. Том первый. Wien: Wiener Slawistischer Almanach. Sonderband 42.

Пригов Д.А. (1997а): Написанное с 1975 по 1989. М.: Новое литературное обозрение.

Пригов Д.А. (1997б): Советские тексты. СПб.: Издательство Ивана Лимбаха. Пригов Д.А. (2017): Монады - https://iknigi.net/avtor-dmitriy-prigov/132 o65-monady-dmitriy-prigov/read/page-17.html (20/07/2019).

Пузырев А. В. (2014): О системном подходе в лингвистике. - М.: ВНИИгеосистем.

Пушкин А.С. (1956-1958): Полное собрание сочинений в 10 томах. Изд. 2-е. М.: Издательство АН СССР.

Рубинштейн Л. (2013): Это всё - www.zerkalo/2013/42 (o8/o8/2019).

Рыжий Б. (1997): Еще не погаснет жемчужин... - https://45parallel.net/boris_ryzhiy/esche_ne_pogasnet_zhemchuzhin_sotsvetie.html (o1/o6/2019).

Самойлов Д. (1989): Избранные произведения в двух томах. М.: Художественная литература.

Самойлов Д. (1992): Из последних стихов. Таллинн: Александра.

Сахарный Л.В. (1994): Человек и текст: две грамматики. В кн.: Человек Текст - Культура / Под ред. Н.А. Купиной, Т.В. Матвеевой. Екатеринбург: Институт развития регионального образования. С. 7-59.

Северская О.И. (2019): Поэтика перестройки и «перестройка» поэтики: о влиянии эпохи на язык русской поэзии 1980-200о гг. // Известия Уральского федерального университета. Серия 2. Гуманитарные науки. Т. 21, № 1 (184). С. 134-154. 
Слуцкий Б. (1984): Сроки. М.: Советский писатель.

Соболева Л.И. (2002): Динамика фонетической структуры одного стихотворения Осипа Мандельштама. В кн.: Русский язык. Система и функционирование. Материалы международной научной конференции 17-18 апреля 2002 г. Ч. І. Минск. С. 94-97.

Соснора В. (1989): Возвращение к морю. Л.: Советский писатель.

Стеблов Е. (2010): Против кого дружите? Ростов-на-Дону: Феникс, М.: Алгоритм.

Степанов А.Г. (2002): О семантике переноса: замечания к проблеме. В кн.: Архетипические структуры художественного сознания. Выпуск 3. Памяти В.В. Короны. Екатеринбург: Издательство Уральского государственного университета. С. 139-144.

Степанов Е. (2011): Анжамбман как стилистический прием поэтов XXI века // Дети Ра. № 2. - www.magazines.russ.ru/ra/2011/2/st42.html (20/04/2019).

Степанова Л. (2020): Фразеологические единицы в современной русской поэзии и способы их перевода на чешский язык. В кн.: Язык русской поэзии конца XX - начала XXI веков. Trier (в печати).

Стуков Г. (1965): Поэт-«тунеядец»- Иосиф Бродский. В кн.: Бродский И. Стихотворения и поэмы. New York: Inter-Language Literary Associates. C. 5-15.

Супрун А.Е. (2001): Исследования по лингвистике текста: Сборник статей. Минск: БГУ.

Сухарев Д. (1989): При вечернем и утреннем свете. М.: Советский писатель. Тарковский А. (1982): Избранное: Стихотворения, поэмы, переводы (19291979). М.: Художественная литература.

Толстая Т. (2006): Не кысь. М.: Эксмо.

Устинова Т. (2007): Хроника гнусных времен. М.: Эксмо.

Ушаков Д.Н. (ред.) (1935-1940): Толковый словарь русского языка. Т. I IV. М.: Советская энциклопедия.

Ушакова Т. Н. (1979): Функциональные структуры второй сигнальной системы. Психофизиологические механизмы внутренней речи. М.: Наука.

Фет А.А. (1986): Стихотворения и поэмы («Библиотека поэта. Большая серия»). Л.: Советский писатель.

Фуко М. (1994): Слова и вещи: Археология гуманитарных наук. СПб.: А-cad.

Хармс Д. (1988): Полет в небеса: Стихи. Проза. Драма. Письма. Л.: Советский писатель.

Хлебников О. (1986): Местное время. М.: Советский писатель.

Хоменко Ю. (2018): Небо в перьях // Арион. Журнал поэзии. 2018. № 4. C. $82-89$.

Цветаева М. (1984): Сочинения в двух томах. М.: Художественная литература. 
Чернейко Л.О. (1997): Лингво-философский анализ абстрактного имени. М.: МГУ имени М.В. Ломоносова.

Чернейко Л.О. (2012): Асимметричный языковой знак в речи: к вопросу о взаимодействии смыслов в разных условиях их реализации // Вестник Московского университета. Серия 9. Филология. № 2. С. 7-40.

Черниговская Т.В., Деглин В.Л. (1984): Проблема внутреннего диалогизма (нейрофизиологическое исследование языковой компетенции) // Ученые записки Тартуского университета. Труды по знаковым системам. Вып. 17. С. 48-67.

Черниговская Т.В., Деглин В.Л. (1986): Метафорическое и силлогистическое мышление как проявление функциональной асимметрии мозга // Ученые записки Тартуского университета. Труды по знаковым системам. Вып. 19. С. 68-84.

Чечик Ф. (2018): Если по прямой // Арион. Журнал поэзии. 2018. № 4. C. $25-33$.

Чосич Б. (2000): Роль моей семьи в мировой революции. За что боролись. СПб.: Азбука.

Чуковский К. (1965): Собрание сочинений в шести томах. М.: Художественная литература.

Шаламов В. (1988): Стихотворения. М.: Советский писатель.

Шведова Н.Ю. (1960): Очерки по синтаксису русской разговорной речи. М.: Издательство Академии Наук СССР.

Шекспир В. (1982): Гамлет, принц Датский. Сонеты. Ромео и Джульетта. М.: Молодая гвардия.

Шелехов М. (1991): Ангел уличный. М.: Советский писатель.

Шишкин М. (2006): Венерин волос. М.: Вагриус.

Щерба Л.В. (1974): Языковая система и речевая деятельность. Л.: Наука.

Якобсон Р. (1983): Поэзия грамматики и грамматика поэзии. В кн.: Семиотика / Сост. Ю.С. Степанов. М.: Радуга. С. 462-482.

Якобсон Р. (1987): Работы по поэтике. М.: Прогресс.

Яновская Л. (2007): Записки о Михаиле Булгакове. М.: Издательский дом «ТКСТ».

Admoni W. (1986): Der deutsche Sprachbau. М.: Просвещение.

Cofer Ch. N., Foley J. P. (1942): Mediated generalization and the interpretation of verbal behavior: I. Prolegomena // Psychological Review. Vol. 49. Pp. 513-540.

Gadamer H.-G. (1975): Wahrheit und Methode. Grundzüge einer philosophischen Hermeneutik. Tübingen: J.C.B. Mohr.

Kainz F. Psychologie der Sprache. Vierter Band. Spezielle Sprachpsychologie. Stuttgart, 1967. 
Kecskes I. (2010): Situation-bound utterances as pragmatic acts // Journal of Pragmatics. 42. Pp. 2889-2897.

Nietzsche F. (1908): Le Crépuscule des idoles. Mercure de France.

Reuther T. (2003): Semantische Primitiva (Englisch, Russisch, Deutsch) // Slavistische Linguistik 2001. Referate des XXVII. Konstanzer Slavistischen Arbeitstreffens Frankfurt/Friedrichsdorf, 11.-13.9.2001 / Herausgegeben von H. Kusse. München. S. 287-307.

Thoms G. (2008): When sentences are not sentences: evidence against poetic grammar // On-line proceedings of the annual conference of the Poetics and linguistics association (PALA'2008). https://www.pala.ac.uk/uploads/2/5/1/o/25105678/thoms2008.pdf (11/o8/2019). 


\section{Trierer Studien zur Slavistik}

Herausgegeben von Alexander Bierich, Gerhard Ressel und Henrieke Stahl

Band 1-3 sind erschienen bei Biblion Media, Leipzig.

Band 4 Angelika Schmitt: Hermetischer Symbolismus: Andrej Belyjs „Istorija stanovlenija samosoznajuščej duši“. 2019.

Band 5 Alexander Bierich, Thomas Bruns, Henrieke Stahl (Hrsg.): Gedächtnisraum Literatur Gedächtnisraum Sprache: Europäische Dimensionen slavischer Geschichte und Kultur. Festschrift für Svetlana und Gerhard Ressel. 2019.

Band 6 Alexander Bierich, Thomas Bruns (Hrsg.): Sprachgeschichte und Sprachwandel im Slavischen. Festschrift für Jadranka Gvozdanović. 2019.

Band 7 Борис Норман: Языковые категории в сознании и творчестве русского поэта. 2020.

www.peterlang.com 